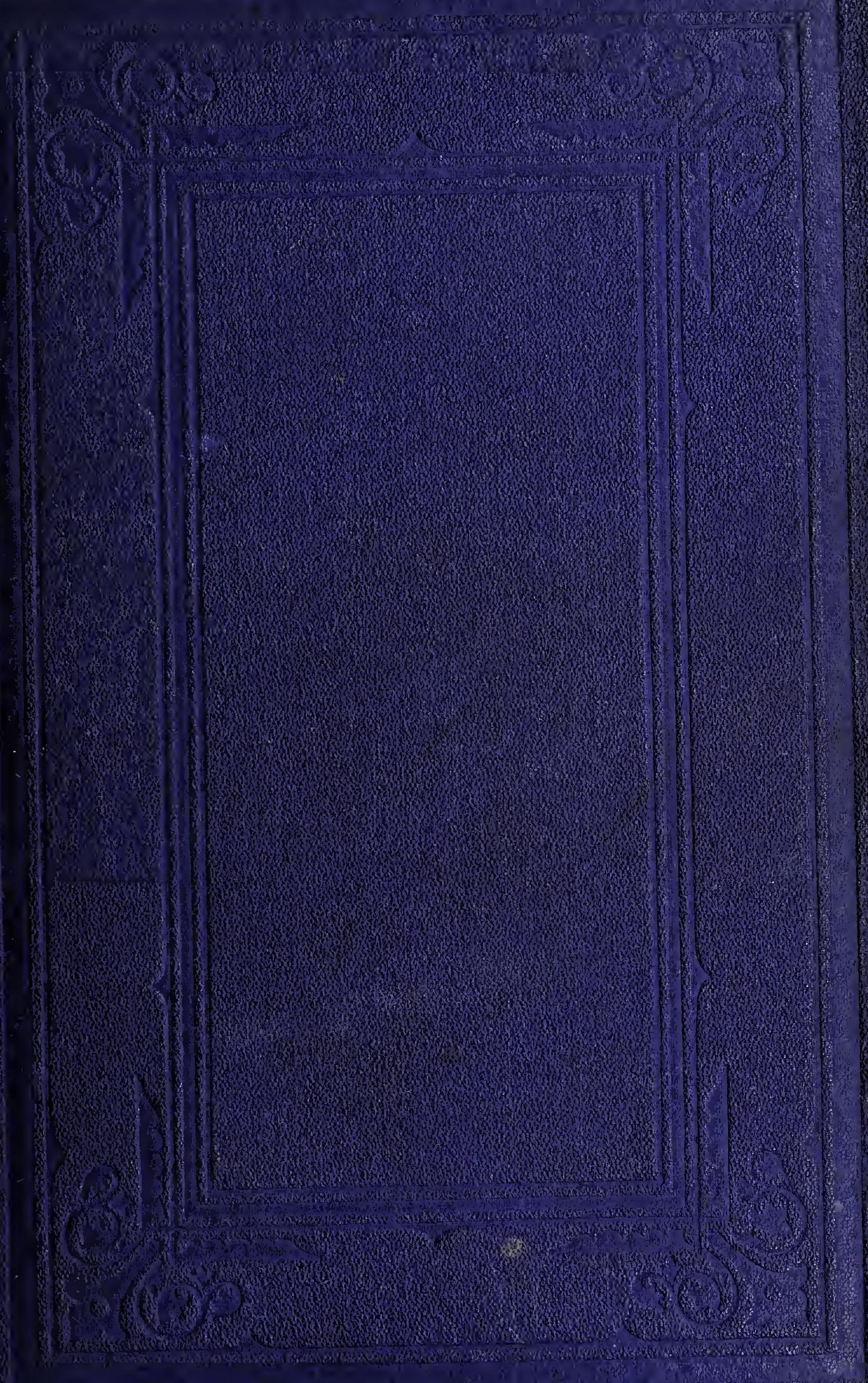


19863376

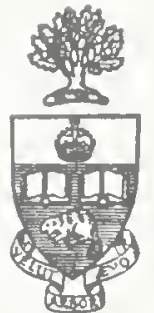

Library

of the

University of Toronto 
Digitized by the Internet Archive in 2018 with funding from University of Toronto 

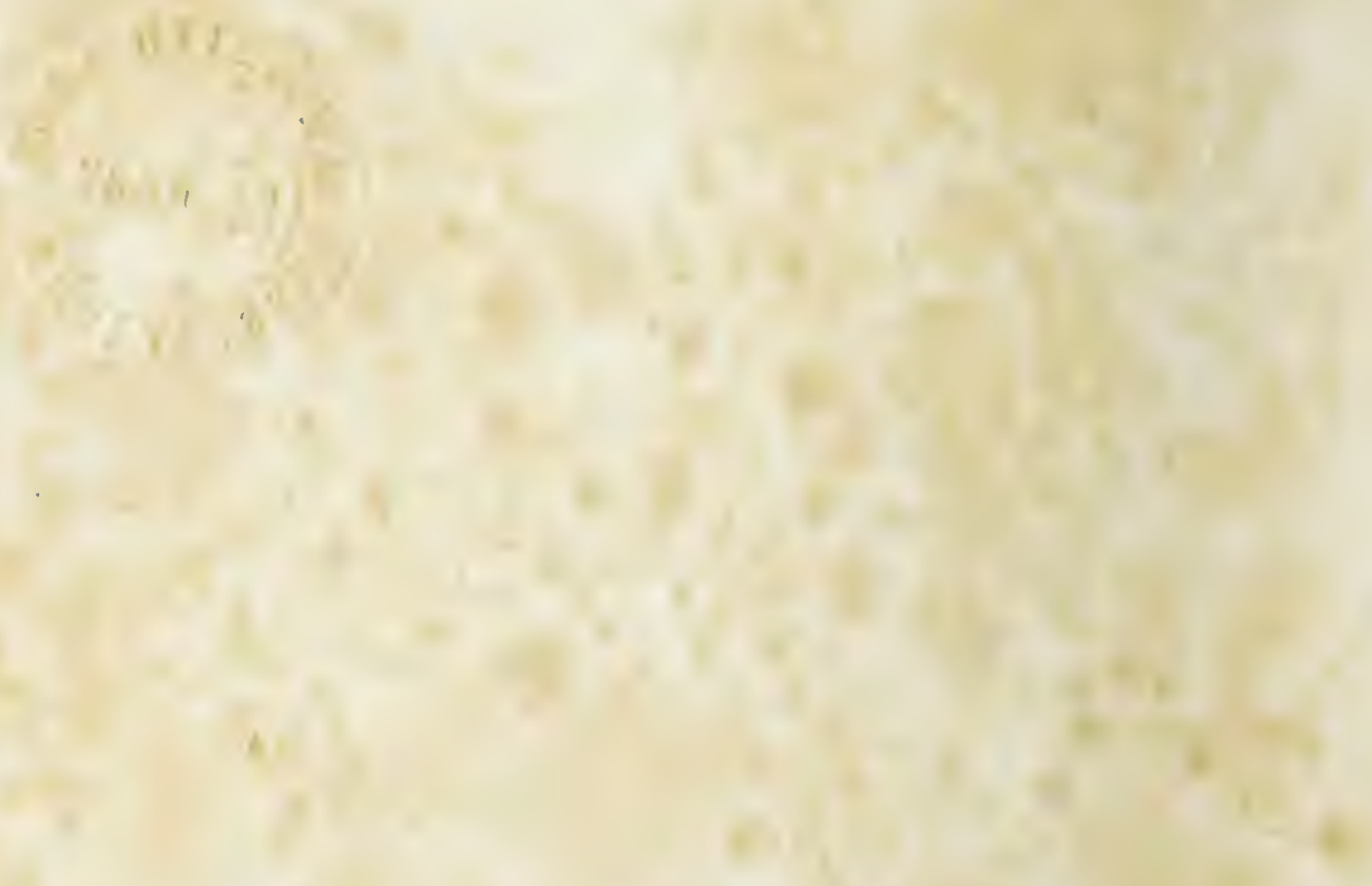


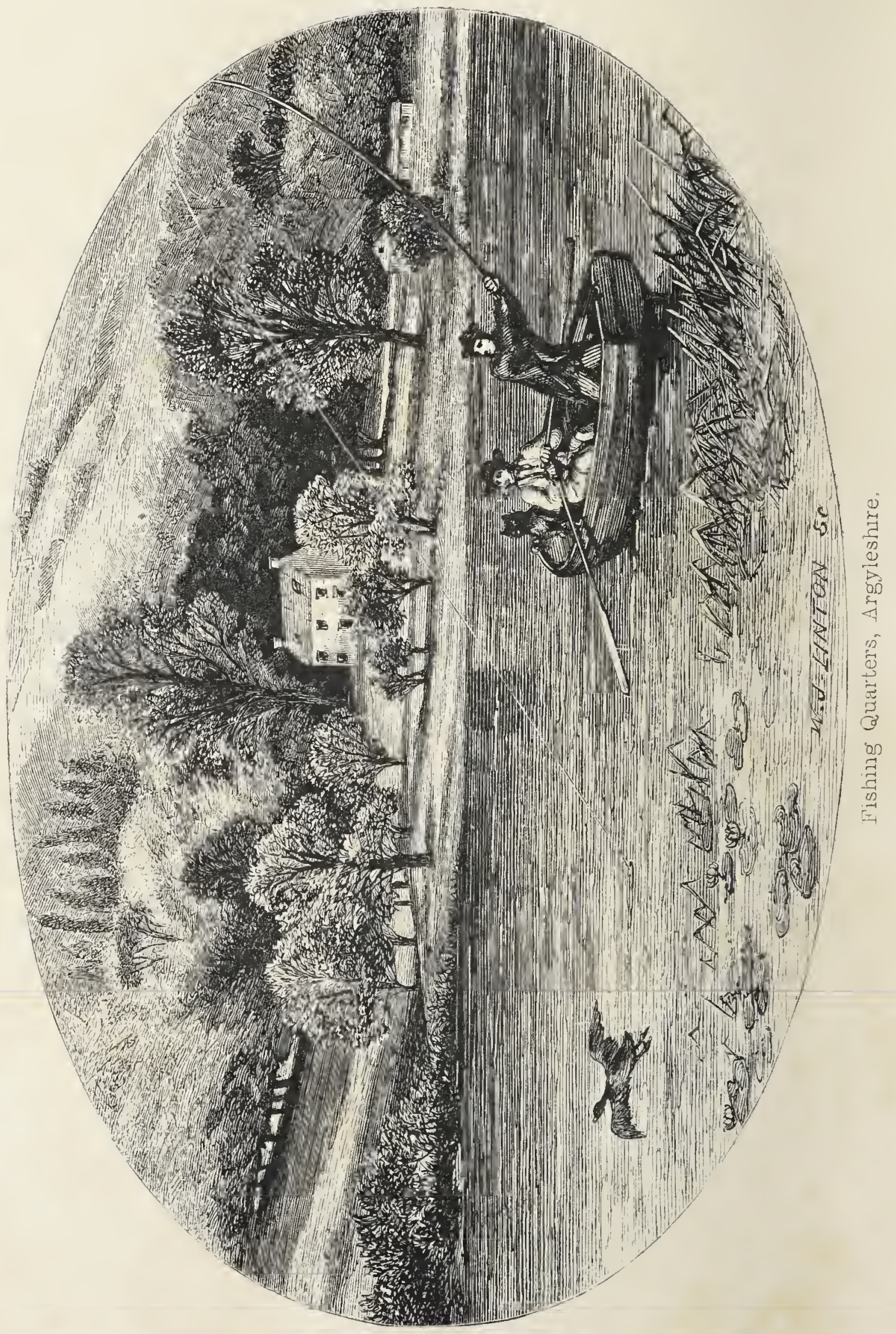




\section{STRAY NOTES}

O $\mathrm{N}$

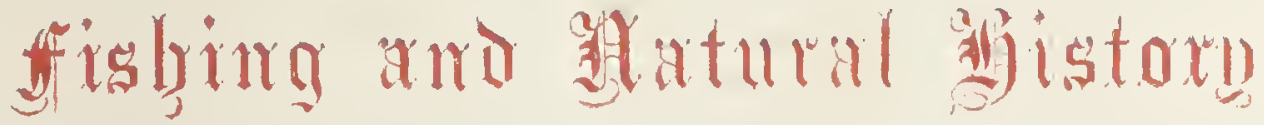

$\mathrm{BY}$

CORNWALL SIMEON.

I wind about, and in and out,

Witlı here a blossom sailng,

And here and there a lusty trout

And here and there a grayling.

Tennyson, The Brook:

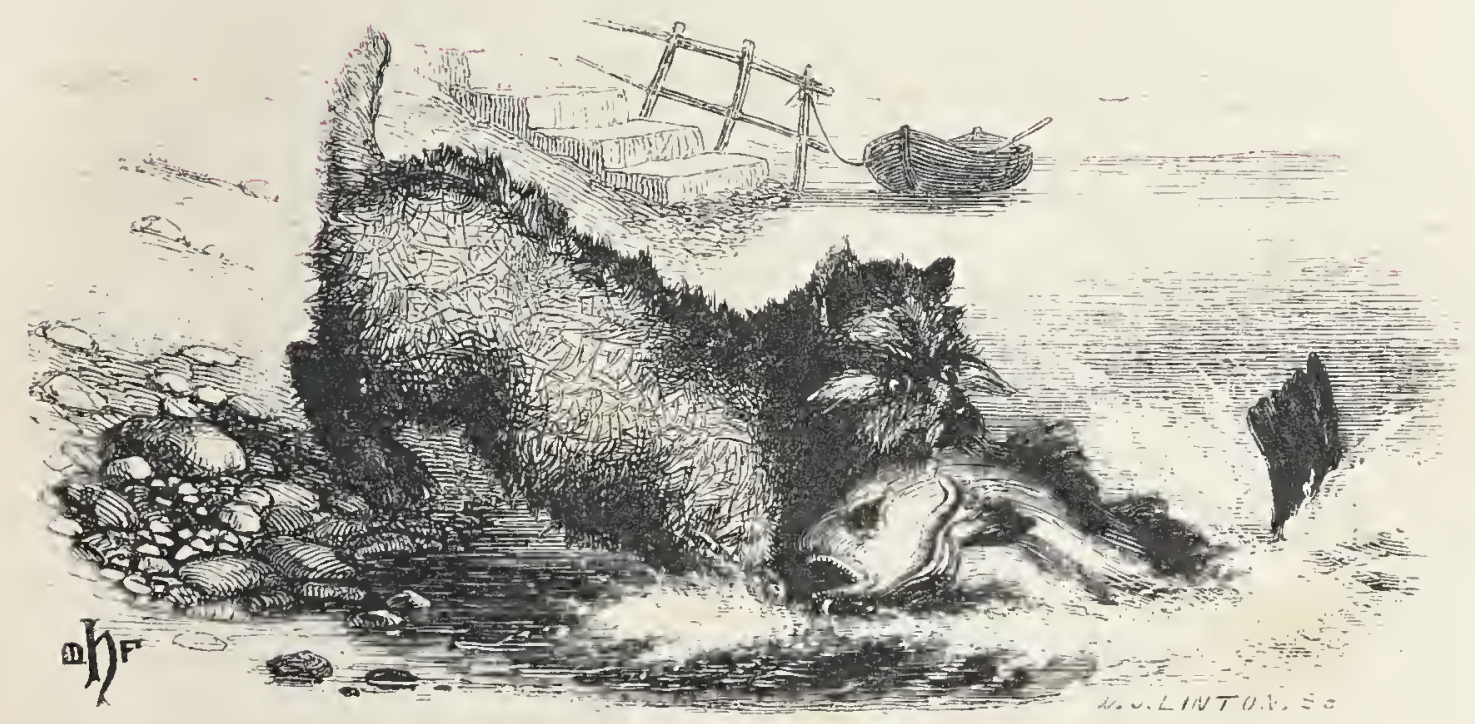

Cambríoge:

MACMILLAN AND CO.

AND 23, HENRIETTA STREET, COVENT GARDEN,

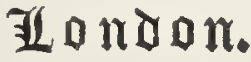

1860. 


\section{Cumbrioge:}

PRINTED BY C. J. CIAY, MLA.

AT THE TINIVERSITY PRESA. 


\section{PREF A CE.}

The following Notes were, with but few exceptions, written originally without any view to publication, being merely jottings of matters from time to time occurring to my notice, recollections of which I wished to preserve for my own amusement. When it was afterwards suggested to me that some leisure hours might be employed in rendering them presentable to others, I thought it better-while it was certainly easier-to leave them generally as they had grown up under my hand, rather than to attempt a more connected arrangement, or even to reduce them to anything like order. This I trust will be considered a sufficient excuse for the abrupt and desultory form in which they are now offered to the Public. 
So far as they relate to Fishing, those connected with practical details are almost entirely the result of my own experience, and I may therefore hope that they will prove not altogether useless to brother-fishermen, while such as are not exclusively technical may perhaps possess a more general interest.

With regard to those connected with $\mathrm{Na}$ tural History I feel that an apology is needed - especially in this eminently scientific agefor my presumption in venturing to deal with the subject so superficially. There is, indeed, nothing in these Notes which can commend them to the man of science, they being merely records of every-day matters, which, though simple in themselves, have nevertheless yielded me so much interest and pleasure, that they may, it is hoped, even second-hand, be capable of affording some amusement to others.

The combination of the two subjects is one which may be thought to require some explanation.

By those who take no interest in Fieldsports, Hunting, Shooting and Fishing will 
be, naturally enough, classed together in the same category (without any regard to their bearing on other subjects) as simply representing the pursuit of so many descriptions of animals; and the connexion of all three with the study of Natural History will be probably considered as equally remote and indirect.

Now, as to the two former, they may to a certain extent be right; an attempt to join either Hunting or Shooting with Natural History - as Fishing is joined in the following Notes-might perhaps be fairly open to exception, as a union of two subjects not of themselves sufficiently connected.

But Fishing, to my mind, occupies in that respect an entirely different position from the other two, the affinity between it and the study of Natural History being so close and distinct, as to warrant their being: thus coupled together, I submit, without the slightest violence to either.

As, however, the distinction to be drawn between the three sports would probably not 
immediately suggest itself to those who take no interest in them (and I am anxious, as a Fisherman, to establish it, and to vindicate the appropriateness of my Title) I will briefly mention the points of difference which seem to me thus far to separate them.

Far be it from me in doing this to extol Fishing at the expense of IIunting or Shooting; I am much too fond of and grateful to them to have the least inclination to do so, even if it suited my purpose. It is merely to accident that Fishing is indebted for the auxiliary charm of this fellowship with $\mathrm{Na}$ tural History: that Hunting and Shooting are in great measure destitute of it is not their fault but their misfortune.

In the first place, exactly as both season, and the circumstances under which their several pursuits are conducted tend to frustrate any attempt on the part of those who hunt or shoot ${ }^{1}$ to cultivate the study of Natural

1 It seems strange that whilst the language affords two words ("Angler," and "Fishernan") descriptive of the man who fishes, we should be driven to paraphrases for want of corresponding worcis with regard to Hunting and Shooting. 
History; in the same proportion do they not only lead the Angler up to it, but actually almost force it upon him.

The former (for whose purposes a very limited knowledge of Natural History is generally sufficient, and whose sports are attended with a degree of noise and bustle, at once disturbing some objects which might otherwise attract their notice, and incompatible with a careful examination of others) take the field when the leaf is withering, and

As to the former, "Hunter" and "Huntsman," though both originally bearing that signification, have now lost it, the word "Hunter" being (in England) now generally transferred from the man to the horse, whilst "Huntsman" is exclusively applied to the person who manages the hounds. As to the latter (Shooting) we are, if possible, still worse off, for "Shooter" can scarcely be considered to have been ever commonly adopted, "Shooting-man" is utterly inadmissible, and "Shot," if it ever conveys a similar meaning, certainly fails to do so without a qualifying adjective.

The French, German, Italian, and Spanish languages have, it may be remarked, no advantage over us in this respect. In each there is a word to designate the fisherman ("Pêcheur," "Fischer," "Pescatore," and "Pescador"), yet when they come to Hunting and Shooting they are obliged to take refuge in generalities, combining the words "chasser"- "jagen""cacciare"-_cazâr," \&c., with others expressive of the particular sport. 
the Swallows are already congregating for their southern flight; and retire from it (with rare exceptions) before they have again heralded the spring, or the earth has reawakened from her long winter-sleep. Such, it must be admitted, is not the season, nor are such the circumstances which can in any great degree tend to promote a love for, or conduce to, the study of Natural History.

But how different is the Angler's case! Not only is an accurate knowledge of some branches of Natural History essential to him who would excel in his art, but all the circumstances attending it-the genial character of the season which peculiarly calls him forth - the beauty of the scenery into which he is naturally led, with all its sweet accompaniments,

"Rivers to whose shallow falls

Melodious birds sing madrigals ;"-

the soothing and thought-awakening influence of the water itself, "Nature's store-house, in which she locks up her wonders" - the num-

I Izaak Walton. 
berless and varied forms of animal and vegetable life, which can hardly fail to arrest his attention and excite his interest, many of them, by reason of the silence and quiet necessary for his sport, being seen to especial advantage; all these things combine not only to present the works of Nature before him in their most attractive form, but at the same time peculiarly dispose his mind to meditate on the impressions they can scarcely fail to make on it. The Book of Nature is in fact opened before his eyes-nay, obtruded on his notice -written in such distinct and inviting characters, that he must indeed be blind of eye, and dull of apprehension, if he do not, to some extent at any rate, attain to a knowledge and a love of her language.

It is scarcely to be wondered then, that, springing from all these associations, there should insensibly arise in the Angler's mind a cordial sympathy with and appreciation of the delights and wonders of Nature, such as I am persuaded no other class of men (taken collectively) possesses. 
xii PREFACE。

The accuracy of these conclusions, as between Hunting, Shooting, and Fishing, may be, perhaps not unfairly, tested by comparing the standard works on each, and thus forming an estimate of the regard in which Nature and the study of Natural History are held by their respective votaries.

To go through the whole list would be a tedious and a needless process; but let us take the best known work on each subjectsay Beckford's Thoughts on Hunting, Hawker's Instructions to Young Sportsmen, and Walton's Complete Angler. Now what is there in "Beckford" but Hunting,- what in "Hawker" but Shooting? But what a change is there when we come to dear old Izaak! How keen and pure is his appreciation and enjoyment of Nature for Nature's self. There is scarcely a page in his whole book which does not breathe forth his earnest and devoted love for her. Do not his descriptions almost lead away his readers in spite of themselves from the avowed subject of his book, and incite them to become Anglers more for the sake 
of the accessories which he paints so graphically and invitingly-his "honey-suckle hedges"-his "airy creatures" - his "silver streams" - than for the actual fishing ? I verily believe he has done as much to promote a genial and healthy love of Nature as any man who ever lived.

That Fishing has, by thus leading up to the study of Natural History, acquired a prescriptive right to be associated with it-as I have taken leave to do in the subsequent Notes-is a question which no angler would probably dispute.

1 Yarrell says, that few have expressed their admiration of the Nightingale's song in more fervent or more natural terms than "honest Izaak Walton, who loved birds almost as well as he loved fish,"--quoting from him that graphic eulogy of the bird:- "But the Nightingale, another of my airy creatures, breathes such sweet loud music out of her little instrumental throat, that it might make mankind to think that miracles are not ceased. He that at midnight, when the very labourer sleeps securely, should hear, as I have very often, the clear airs, the sweet descants, the natural rising and falling, the doubling and redoubling of her voice, might well be lifted up above earth, and say, 'Lord, what music hast thou provided for the saints in heaven, when thou affordest bad men such music upon earth." "-British Birds, I. 319. 
Should my pleadings for the "gentle art" induce any others who might have been inclined to dissent from this view of the case, to refrain from pronouncing an opposite opinion, my preface will have fully answered its purpose,- - so will the Notes themselves, if they at all tend to promote a love for Fishing and Natural History. He must indeed be a churl, who would not wish to see his friends participate in the great pleasures which these sources will never fail to afford him.

In conclusion, it may be satisfactory to the reader to know that (so far as I am aware) every statement in the Notes may be implicitly relied on. At least I can assure him that I have throughout studiously endeavoured to guard against exaggeration, and that any inaccuracies which may have crept in amongst them have proceeded wholly from inadvertence on my part.

To my friends $\mathrm{Mr}$ A. Z. Palmer, Mr L. Dickinson, and Mr Halliday, my best acknowledgments are due for their kind and valuable co-operation, to which I owe the engravings 
which at once ornament and illustrate the Notes,-the original drawing from which the frontispiece is taken being by $\mathrm{Mr}$ Dickinson; the spirited little vignette (of the Terrier and Cod) by Mr Halliday, and the illustrations of fishing-tackle (with one or two exceptions) by Mr Palmer.

I trust that the reader will consider the circumstances which led to the appearance of these Notes in their existing shape as also (to some extent) excusing the imperfections of which I am conscious in their style;-for the rest I must throw myself upon his good nature and forbearance. 



\section{CONTENTS.}

\section{PaRT I.-FISHING.}

\section{CHAP'TER I.}

Directions for Spinning-Rod-for Trout-for JackCovering for Button-Rings-Line-Trace-_ShotFlights of Hooks-Baiting-Gimp-Treble GutSingle ditto - Care as to Tackle - "Hand-coiling" Line-A couple of hints-Colour of Landing-handle

\section{CHAPTER II.}

Spin slowly-Strike Jack sharply-Artificial baits for Jack-Jack caught with dead bait not in motion"Kill-devils" - on the Wandle-in Devonshire-in Salt-water - Spoon-baits - India-rubber balls for floating off live-bait - Double live-bait tackle"Gag" and "Executioner" for Jack-Live-groundbaiting . . . • . . • .

CHAPTER III.

How to catch Carp-Tame Carp_Carp basking-Grasshopper bait_Carp, Eels, and Aschylus-Fish-ponds near Brussels-Great Carp caught in them-General management of fish there-Growth of fish promoted by change of water-Effect on Jack-on RoachNoises made by Carp at night_-Spawning of CarpTheir spawn devoured by Water-birds and fishDace caught with Spinning-bait-Carp with live Minnow-Eel with fly-Perch with fly . .

CHAPTER IV.

In selection of Flies, colour, not form-Old rule, "Light fly for darkness," \&c. rather to be reversedFastening for Casting-line-Ditto for Bob-fliesMake-shift Gaff-Cut-and-thrust Rod-spear-Simple Clearing-line-Fastening for loose Reel-Fish slowly with fly-Straight line-Hair casting-linesTailing fly witl "Gentle"-Fishing near GenevaVersoix-Eau de Lyon-Lines on Versoix-In 
Trailing, side next shore best-In Sea-fishing, ste:n of boat better than bow . . . . . .

CHAPTER V.

On Sea-fishing-Fine Tackle required-Best form of Tackle for general use-"Tell-tale" or "Dodger"Baits-on South Coast_in Scotland-Fly-fishing in Sca-lochs-Mode of proceeding-Gaff essentialExecutioner

\section{CHAPTER VI.}

Lochs on West Coast of Scotland-Animal life-Shellfish-Fish-Plague of Dog-fish-Lobsters-Salmon and Sca-trout-A singular trio-Salmon detained in Salt-water become diseased-Artificial "Spate" for Salmon-Salmon passively following the line when hooked

CHAPTER VII.

Fishing from Steamers-Whiting near the surface-A day in the Linnhe Loch-off the Brambles-Ladybirds at sea-Boat-dress for bad weather-Advantages of Cape-Other Hints as to Dress-Knickerbockers-Belt-Cap-How to pair Gloves-Fishtaxidermy

CHAPTER VIII.

Spearing Flat-fish-Have Flat-fish the power of changing colour at will ?-Spearing ditto off Ryde-Nest of Stickleback-Deceptive appearance of fish in water-Instances-of Jack-of Trout . . . 106

CHAPTER IX.

Ember-cooking Fish-Fishing in Glen Garry-Big Salmo ferox-A Fisher-dog . . . . . .

\section{CHAPTER X.}

Eels held in abhorrence by Scotch-Scruples orercome -Fox-hunter-"Snakes and Puddock-stools"-Deformed Trout-Brown Trout in Glomach--in the Findhorn-"Great spotted Ling"-Singular effect of fish-diet-_"Sour Skate"-Queer fancy of Cow. 


\section{Part II.-NATURAL HISTORY.}

\section{CHAPTER I.}

Nest of Mason Wasp-Larve under water-lily LearesBirds misled by unseasonable weather-Tameness of Robins-Tameness of Wood-pigeon during breeding-scason-of Whitethroat-of Partridge-Tame Gulls-Tameness of Gulls in general-Their flight variable according to weather . . . . .

\section{CHAPTER II.}

Do Birds understand what they say?-Anecdotes in point-Sand-martins at Weybridge-Swallows killed by Parasites-Swan feeding Cygnets-Cock-turkey as Nurse-Disposition of Egg-shells in Nests of Partridges, \&c.-Eggs of White Pheasant-of Himalayan ditto-Hatching by Pheasants and Hens compared-Two Species of Land Lizards-Large Lizard in Spain-Estremadura-Black ViperFetidness of Common Snake-Snake and Eel . 161

\section{CHAPTER III.}

Strength of Moles-Popular notion respecting themBarger-White Fox-Fondness of Cows for bonesStinking Goat-Fascination of Human Eye on Birds - Charming away Warts-Fancies taken by Animals - Spaniel - Squirrel - Macaw-Kitten-Cur baptism-Dog's ear for Music-Growling at "strangers" in tea

CHAPTER IV.

Buzzards - pair of-anecdote as to-Return of Migratory Birds to same haunts - Same harbour holds Trout of same size-Starlings-breeding of in the Isle of Wight-large flock of-Visitation of BuntingsIncrease of Wood Pigeons-Their numbers fluctuate 


\section{CHAPTER V.}

Rarcr Birds visitors to the Isle of Wight-Spoon-bill-

Red-nceked Phalarope-Bittern-Gannet-Whitefronted (Laughing) Goose-Black Redstart-Common Ditto-Hoopoe-Snow Bunting - Cirl Bunting - Brambling - Merlin - Hobby-Grossbeak-Wryncck-Grasshopper Warbler-Stone Curlew-Dotterel-Ring Dotterel and Ox-bird-Grey PloverGolden Pluver-Protest against killing rare Birds .

CHAPTER VI.

Tameness of Animals on Sundays-Anecdotes as to Horses-Spaniel-Pomeranian Dog-Note of Peewit-Grass scarified by Rooks-Barencss at base of Rook's bill-Infants-Young Asses-Young Elephants-Lofty flight of Moorhens at night-Landrail-Quail-Woodcock-carries young from place to place-Snipe-Squirrels-Nuts and Nutshel's on Down-Star on Hare's forehead-Sparrows congregating in hard weather . . . . . .

CHAPTER VII.

Singular effect of Storm-Grcat discharge of Sap from Trces-Growth of Cedar of Lebanon-of other Trees-Changes in Pond-weeds-Soil collected at mouths of Worm-ho'cs-Maggots from Sca-weedDiscase among Partridges - Boy and WaspsMidges-Birds on Scotch Sea-lochs-Herons in Loch Duich-Mortality among Sea-birds-Skeletons of Weasels in Ricks-Rats

\section{CHAPTER VIII.}

Determination of Sparrow-hawk-Boldness and voracity of Stont-Jays-bait for-Flocks of Magpies-Jays, Magpics, \&c. subject to fits-Raven-Cats-Barnowls-Kestrels-Foxes

NOTE.

Pike choked by living Carp . . . . . . 256 


\section{PA R T I.}

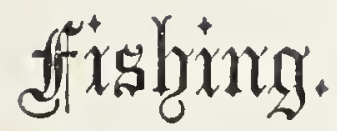





\section{F I S H I N G.}

\section{CHAPTER I.}

Directions for Spinning-Rod-for Trout-for Jack-Covering for Button-Rings-Line-Trace-Shot-Flights of Hooks-Baiting-Gimp-Treble Gut-Single dittoCare as to Tackle-"Hand-coiling" Line-A couple of hints-Colour of Landing-handle.

T HAVE experienced so much difficulty in de1 termining what is (to miy mind) the best form of tackle for spinning, that I make no apology for submitting to those who are fond of this very pleasant mode of fishing the results at which I have arrived. And I do so without hesitation : not that I have the slightest intention of asserting my style of tackle to be perfect, (for most old fishermen have their own peculiar wrinkles, many of which might probably be adopted with advantage, in addition to, if not in lieu of, my own,) but simply because, having in vain consulted the ordinary books on fishing for the information I required, I should have been very 
glad some years ago to obtain that which I now offer as the result of actual experience; and, believing that the want has not yet been supplied, I think it not improbable that others may still be in the same case.

Your spinning-rod (for Trout) should not be shorter than twelve and a half, nor exceed sixteen feet in length. For boat-work, and indeed when fishing from the shore, if the water is sufficiently deep along the side next you, and the bank clear, one of about thirteen feet will generally be found to answer every purpose: but for use off weirs, or from the bank where the water runs shallow near the shore, or is grown up with reeds, it is generally advisable to have a somewhat longer one.

Cane is the best material for the whole of the rod except the top, for which, in my opinion, nothing beats simple hickory. A rood called "green-heart" has been a good deal praised lately as a material for tops, but I fancy it is, though sometimes very tough and elastic, apt to run faulty, and therefore not always to be depended on. One great advantage of cane is its lightness, a quality which, having due regard to strength, can hardly be too much insisted on ; for a con- 
tinuous day's spinning, when you are out of practice, is back-aching work even with a light rod, much more so with a heavy one.

A trout-spimning-rod can generally be converted into one applicable to Jack, by substituting a short stiff top for the longer one, or (if extraheavy baits be used) for the two upper joints required for lighter and finer work. Where however very heavy baits are exclusively employedthe fashion in some places, though I by no means recommend it for general adoption - it will be found a matter of economy to have a stouter rod built for the purpose, as the undue strain to which a light rod would be thus subjected would soon ruin it, however good it might be.

A rod if well made, and of good materials, will with care last a long while. I myself have a cane one which was made for me about seventeen years ago by Bowness (late Chevalier) of Bell Yard, (whose materials and workmanship I have always found extremely good,) which has been in pretty constant use ever since, and-barring a joint which was accidentally broken, and has been renewedseems scarcely to have suffered from the work it has done.

Over the button at the bottom of the rod 
should be strained and fastened a piece of washleather,--or, what is perhaps better, thin Indiarubber-which will be found of great service and comfort in preventing the rod from slipping, as it is otherwise sometimes inclined to do, when you are throwing under difficulties.

By all means have your rod-rings sufficiently large. They should of course be fixed upright. Very good ones may be made of thick brass wire, hammered sufficiently to be quite hard without being brittle. That next the hand should be formed by giving the wire a complete turn, and bringing the ends down from above over the rod, thus (Fig. 1): leading them afterwards a little way

Fig. I.

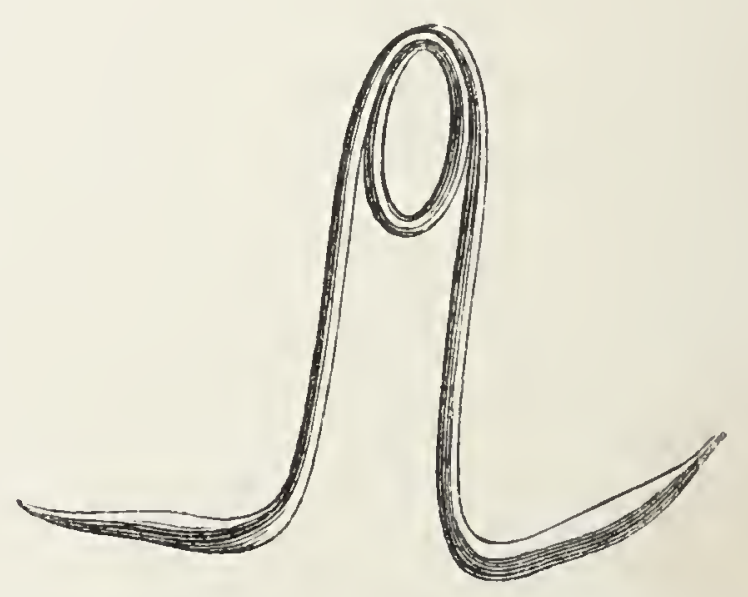

along the butt, to admit of their being whipped on. The line will be thus prevented from getting hung up round the ring, which it will otherwise 
infallibly do sometimes. For that at the end of the rod I think there is nothing so good as a hollowedged ring, of brass or German-silver, enclosed in strong brass wire, as shewn in Fig. 2:-the principal advantage of this plan is, that as the ring can be turned round in the wire, there is no fear of the line wearing a furrow in it, as will be found to be the case after a time, when it is a fixture. Some time ago I mentioned this kind of ring to a London fishing-tackle maker, when he said he thought he could get the

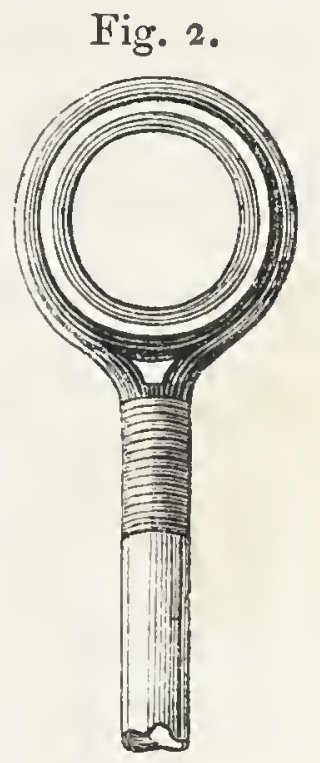
thing nicely done in agate. Rather fancying the material, from the idea that the line would run pleasantly through it, I requested him to have one made for me as a sample. He accordingly did so, when, on inquiring the price, which I ought to have done before, I found it was five shillings! Those of German-silver cost about sixpence a-piece.

It is extremely difficult to get a really good spinning-line for Trout; yet at the same time nothing is more essential to the comfort and the success of the fisherman. The three things which constitute a good line are fineness, softness, and absence of any disposition to "kink." 
Colour should also be looked to, but it is a minor consideration. Of all faults that of "kinking" is the most fatal to sport and temper. If a kinking line does not make a man swear, I don't know what will. The best lines are made of silk, or mostly silk. As good as any that I have seen were made by $\mathrm{Mr}$ Edward Lees, Golden Salmon, Nottingham, price a penny a yard. The line should be dressed occasionally, and that, not by being merely dipped, as London tackle-makers are apt to do it, but by having the composition well rubbed in with the hand. The Thames fishermen, who spin much, are good hands at this. I should recommend any one ordering a new spinning-line, not to have it shorter than a hundred yards. It is not often that so much is required, but it may be occasionally found extremely useful to have a reserve on the reel, as for instance in the case of hooking a large fish from a weir, when you may have to go a long way round before you can bring him down stream to land him; or again your hooks may get foul under the camp-sheeting, when you may save your tackle by going round and getting a pull on it from the opposite direction. At the close, or more frequently at the commencement of a season, you will find it necessary, if your 
line has done much work, to sacrifice some yards of it, which can be more easily spared from a long than a shorter line. When a farourite line has thus become reduced to about sixty or seventy yards, I generally lengthen the end next the reel by splicing and carefully whipping on an additional piece, by which means I still have my old line to throw with, and plenty to fall back upon in case of need. You may thus utilize an old line until the knot comes within the cast. With great care, indeed, the splice may be so nicely made as scarcely to interrupt the passage of the line through the rings, even in casting.

As a length for the trace I have generally found from six to seven feet quite sufficient. A longer one is apt to get in the way; a shorter one brings the line too near the hooks. As to its form, I have come to the conclusion that the following is, for general purposes, as serviceable and convenient a type (admitting, of course, of variation according to circumstances) as any that can be adopted. Above the shot have three lengths of gut (Fig. 3, A), with a swivel between each, as also a swivel and small loop between the lowermost one and the shot. These should be perforate, and made up, separate from the traces, in flights of (say) 
Fig. 3.

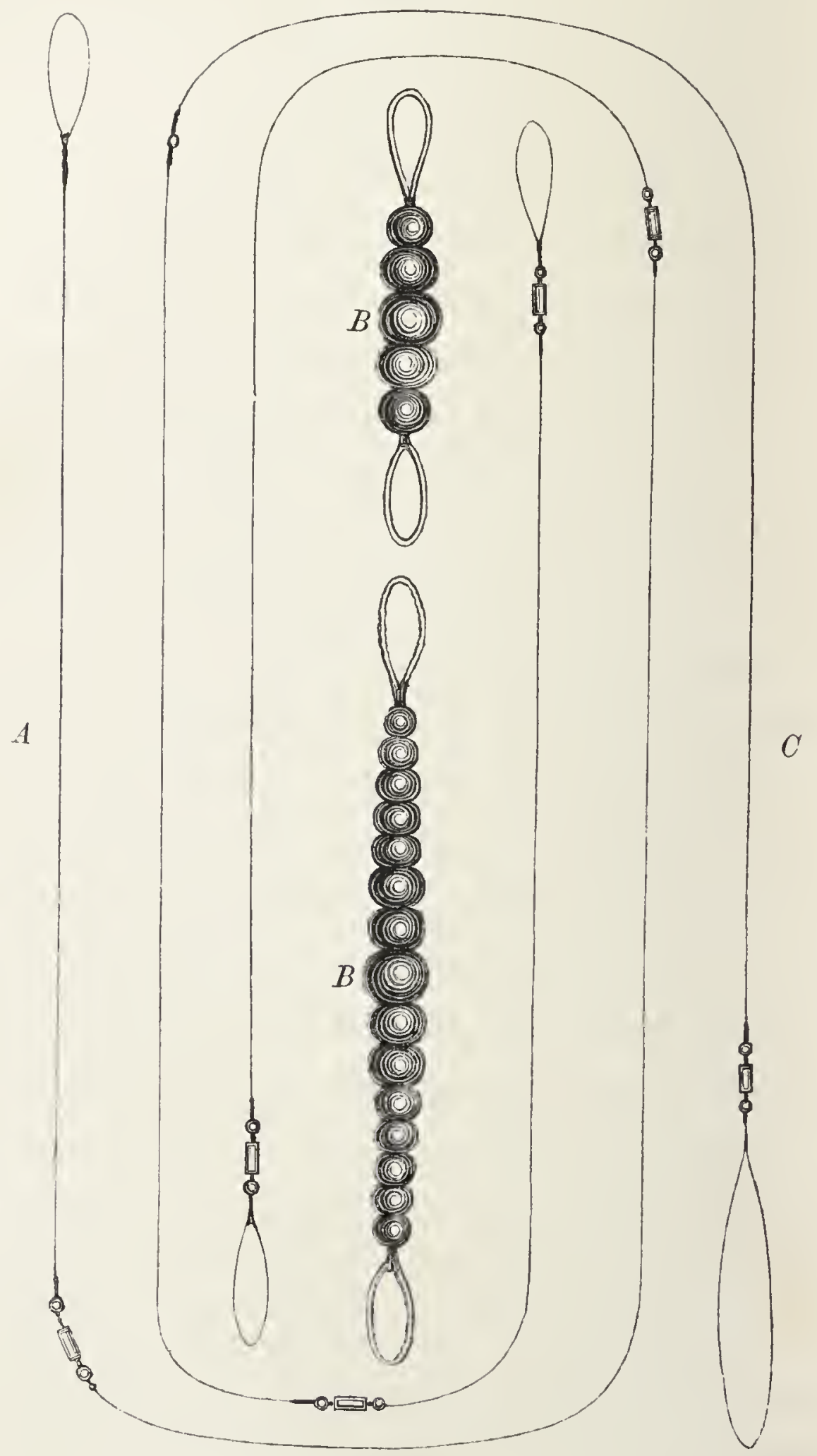


fifteen, twelve, ten, seven, and five respectively (Fig. 3, B), the centremost shots in each flight being larger than the others, which should gradually diminish in size on either side of them. Of these the largest should not be larger than small peas, nor the smallest run below about No. 2; they being thus arranged and sized in order to get the required weight with the least possible disturbance to the water. They should be threaded on treble gut, (not gimp, which is apt to wear;) and a small loop should be left on each side of the flight, so that it can be exchanged at pleasure for a heavier or lighter one, according to the size of the bait, and the state of the water. When, in heavy water, it is necessary to fish with more than about fifteen shot, it is better to have them in two flights separated by about two lengths of gut, to which they should in that case (an exceptional one) be permanently affixed without loops. Below the shot there should be again three lengths of gut (Fig. 3, C), besides the one next the hooks. Between the two upper of these lengths there should be a swivel, and a swivel and loop above and below the three,-the upper loop just sufficiently large to pass the shot through easily,--the lower one large enough to admit of the bait and hooks being 
12 SWIVELS-FLIGHTS OF HOOKS-BAITING. [PART I. passed through it. The number of swivels used will thus amount to six. A smaller number will doubtless often answer the purpose, but that I have mentioned will ensure the bait spinning well, if properly put on, and save your gut from becoming at all twisted. In trailing, when the bait is kept spinning a long while continuously, and the line is not, by being frequently taken out of the water, (as in the ordinary mode of spinning, ) relieved from any undue twist to which it may be subjected, it is almost essential to have as many.

As to flights of hooks, I am content with four, or three, trebles (according to the size of the bait), and a lip-hook, which latter should be tied upon a minute loop, so small as only just to enable it to run up and down the gut. In baiting, it is kept in its place by taking a couple of turns round it with the gut. A single hook, reversed, just below the penultimate treble, tends to keep the tail of the bait in its place. A large bait should always be secured to the hooks by a piece of thread tied round it, just behind, or over, the dorsal fin; otherwise it will soon be dragged from them by its own weight.

A very slight crook in the tail is sufficient to make a bait spin well, especially a large one. In 
fact it should be less and less crooked in proportion to its size. If a bait will not spin well, or "wabbles," two to one it is too much crooked. A double crook or bend in a bait is also absolutely fatal to its spinning properly.

A Bleak should be put on so as to form one continuous curve from head to tail. In all others the tail alone should be curved, and the rest of the body left perfectly straight. This is the theory of Edward Andrews, a fisherman at Maidenhead, who is certainly the greatest "artiste" in putting on a bait that I ever saw.

Further written instructions on the subject I will not attempt, for the most elaborate would fail to teach the knack of putting on a bait properly, it being one which can be acquired only by practice, and which, perhaps as much as any comnected with the gentle art, requires nicety and judgment in its execution.

When fishing water which contains Jack as well as Trout, you should always have by you a few flights of somewhat larger hooks tied on gimp. It is not at all an unfrequent occurrence to lose a set of gut tackle to a Jack, and to recover it by catching him next throw with a gimp set. Indeed, if the gimp be fine, I have generally found that 
it scarcely alarms Trout more than gut, if it do so at all. The very fine gimp should however be always tested before it is used, as the silk within it is apt to be faulty and give. The same remark indeed applies to all kinds of tackle, be it line, single gut, treble gut, or gimp. Remember that when a break occurs it is generally to the best fish. Treble gut is scarcely to be more relied on than single; the fact being that all the weak bad gut is worked up, and looks well enough so. As an instance,-whilst spinning on the Garry, I got my hooks fast the other side of a deep black pool, and, not caring to swim for it, deliberately pulled till something broke. My trace being of single gut, the shot fastened on treble gut, and having gimp next the hooks, I was curious to see which the something would be. It was the treble gut, possibly worn by the rubbing of the shot.

In this, as in all other kinds of fishing, it is impossible, consistently with the requisite amount of strength, to have your tackle too fine: perhaps in no other is it so essential to have the two qualities combined. There are few tackle-makers in London who know much about this branch of their art. Gould, of 268, Oxford-street, (whom I have also pleasure in recommending as a careful 
and painstaking workman,) has probably a more practical knowledge of it than most, being a good fisherman himself: but spinning-tackle is of all the most difficult to get properly made, and no one, who does not make his own, can be too particular in seeing that his instructions are exactly carried out.

There is a plan for managing the line whilst spinning, at which the Thames fishermen are great adepts, and which cannot be too highly commended, by which, instead of being dropped at the feet in the usual way, as it is drawn in after a cast, it is collected in the hollow of the hand, whence it again runs out freely at the next. It is effected by first taking the line between the middle of the fore-finger and the thumb, then turning the hand over, and catching the line above it with the little finger, round which it is for the instant looped, and then turning the hand again, so as to bring the fore-finger and thumb again to bear upon the line. This process is somewhat difficult to describe, and still more so to execute rapidly, as is necessary where there is not much stream, or the water is shallow. The accomplishment is however a very valuable one, enabling the proficient, as it does, to fish comfortably under many circum- 
16 mintS-COLOUR OF LANDING-HANDLE. [PART I.

stances when he could not otherwise do so; as, for instance, in a high wind, in long grass, or off a weir, as well as to carry his line from one part of the water to another in readiness for a cast, instead of dragging it trailing behind him, at the risk of it's getting hung up, and collecting all manner of rubbish in it's course.

With regard to the general management of the rod and line, when spinning, I will only give two hints, which may be useful. All the rest must be learnt by practice. One is to avoid, as much as possible, in the act of throwing, anything approaching to a jerk; the other, after throwing, to let the point of the rod follow the bait until it reaches the water.

The Landing-handle, whether Gaff or Net be used, should always be of a dark colour, if not black. Should the net also be well tanned, it will not only last longer, but be more serviceable while it lasts. It is quite curious how much more readily fish are alarmed by a light-coloured landingstick (cane for instance) than a dark one. Many minutes, which can be ill-spared when the fish are in the humour for taking, are often saved by the use of the latter. A Gaff affixed to a small darkcoloured handle will, if skilfully applied, often 
whip out a fish, before he is aware of his danger: whereas, should he have been once roused to a sense of it, by being brought face to face with a light-coloured one, and particularly if an unsuccessful attempt have been made to land him with it, he often turns unpleasantly fractious, and requires a good deal of persuasion, before he can be again prevailed on to come within reach. And it must not be forgotten, that those struggles of his with a short line are infinitely more dangerous than any that he can make with a long one. 


\section{CHAPTER II.}

Spin slowly-Strike Jack sharply-Artificiul baits for Jack -Jack caught with dead bait not in motion - "Kill-devils" -on the Wandle-in Devonshire-in Salt-water-Spoonbaits-India-rubber balls for floating off live-bait-Double live-bait tackle-"Gag" and "Executioner" for JackLive-ground-baiting.

IF you have fine tackle and a good bait, I am persuaded you can scarcely spin too slowly. In working over a shallow you will find, that by raising the point of your rod you will generally be enabled to keep the bait off the bottom, without in any great degree, and, if you have not much line out, without at all accelerating the speed at which you are fishing. When spinning with an artificial bait the pace may perhaps be greater, as otherwise the fish may detect the imposition. As to slow spinning, the following circumstance would tend to prove my theory :-I was spinning, from a punt, down the reach of the Thames just above Maidenhead, where the stream is not particularly rapid, and not more than four or five feet deep, 
CH. II.] SPIN SLOWLY-STRIKE JACK SHARPLY. 19 (and which had, by the bye, been fished over and over again the same season, and several times the same day,) when my line, which was a new one, becoming kinked, I ceased pulling in altogether whilst clearing it, at the same time raising my rod almost to the perpendicular, to keep my bait off the bottom. Having been in this position some little time-for the kink was rather a complicated one-I felt a tug, but concluded it must have been a weed floating down stream, and took no notice of it. It was, however, almost immediately repeated, when I instinctively struck, and found to my surprise that it proceeded from "no waiter, but a Knight Templar," a good Trout of over three pounds, which I got safely into the landing-net.

You will not often err, when spinning, in striking a Jack too sharply. He gets the bait across his mouth with his big teeth well into it, and nothing short of a good tug will move it so as to get the hooks into him. And the bigger the fish, the more this applies. You feel the fish come at you. You strike him lightly, as you would a Trout,-feel he is on, and think all is right. However, just as you begin to think of playing him, and draw him towards you, you have 
the mortification of finding that he has parted company, and of seeing the wake, like that of a screw-steamer, which the fish, perhaps a beast of fifteen or twenty pounds, has left as a parting token of his size. Pull in your bait and examine it. You will see down the sides of it great scores looking more as if they had been made by the teeth of a leister-spear than of a fish, but all of them, if you notice, simply across the bait. That has been just the cause of your failure. The Jack took it in all earnestness, and held it tight just as long as it suited him, without taking any notice of the gentle touch you favoured him with. Nay, further, being rather hungry, and finding your bait fresh and juicy, just what he fancied, he was by no means inclined to give it up, and only did so at last when he found himself mysteriously drawn along with it in a manner which led him to apprehend danger.

Jack will take an artificial bait much more readily in some water than others. For instance, they may be easily caught with it in the Avon; whilst in the Stour, which meets it just below Christchurch, it is of little use to fish with anything but the natural bait. This, no doubt, depends mainly on the comparative supply of small fish. 
CH. II.] MOTIONLESS DEAD-BAIT TAKEN.

They are, however, generally not very particular as to the kind of bait you have on, and will, when they are hungry, take almost anything which is in motion. Last year, whilst I was trailing up the straight reach below Maidenhead, a Jack came at the length of shot on my line, at least three feet above the bait, and cut the gut there, leaving distinct marks of his teeth in one or two other places. This was perhaps more of a "sell" for me than for him, I having guarded myself, as I thought, against any such contingency by gimp next the hooks.

Although in general Jack decidedly prefer a bait when in motion, yet they will now and then take a dead one lying at the bottom. I have myself once or twice caught them in this way when I have accidentally put down my rod, leaving my bait in the water. On one occasion I remember taking up one on a night-line baited with a worm. Ordinarily I think that only small Jack will be tempted by such a bait, but that such is not invariably the case, the following anecdote will prove:-An acquaintance of mine had been fishing, with some friends, a large pond in the neighbourhood of the New Forest. They halted in the afternoon for luncheon, not having had very 
good sport, when he, wishing to keep his tackle out of the way, and believing the bottom to be clear, threw out his bait (a roach or gudgeon) to some distance from the boat. Luncheon occupied them about three quarters of an hour, at the end of which having taken up his rod, he found his hooks, as he imagined, foul of the bottom. He gave two or three pulls to endeavour to clear it, when he discovered, to his great surprise, that he had got hold of something alive; and the next instant out went his line with evidently a "regular snorter" at the end of it. It was not without considerable difficulty that he succeeded in landing this self-invited guest, when he found him to be a Jack of over twenty-eight pounds, which he has now preserved. I have not yet seen him, but am told he is a singularly handsome fish, so that, if condition be a test, it is probable he was not induced to take the bait merely from the pressure of hunger.

I have fished with artificial spinning-baits (killdevils) of nearly every kind and shape, and caught fish with all, I believe, without exception. Indeed, almost anything at all bright, that will spin, with a garnish of hooks, will, where "baits" are scarce, catch Trout or Jack,-and (I believe I may add) 
Perch. Of the kill-devils with which I have fished, I have caught most Trout with a small brass one, which I got at Bala, pretending no resemblance to a fish, but consisting of a short round body and two large flanges-in size as well as shape like that represented in Fig. 4. The next

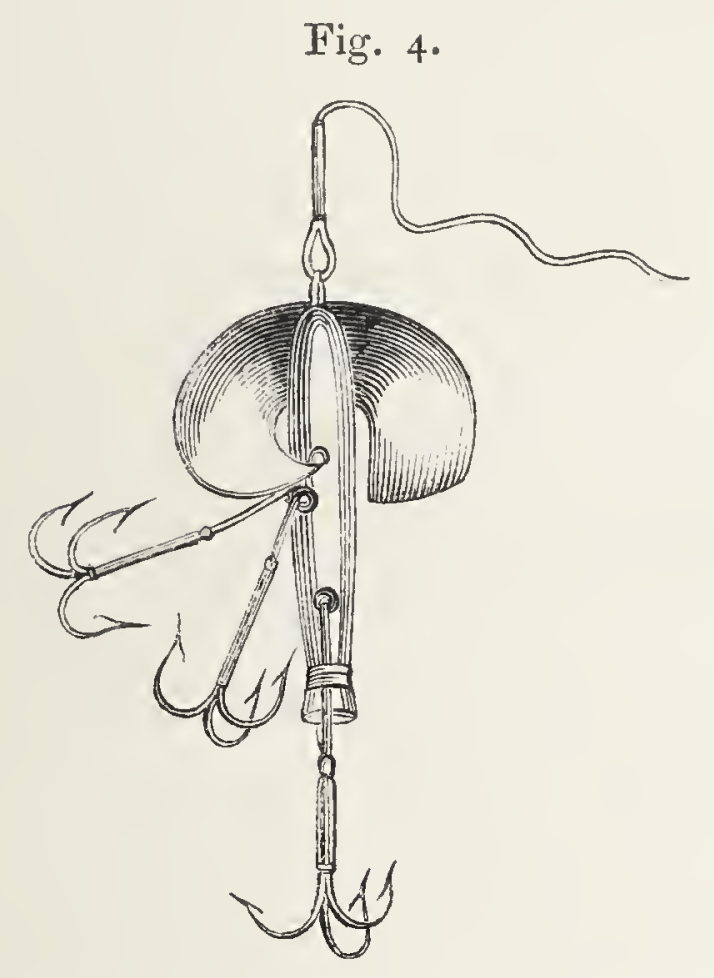

best, which I have principally used when the water contained Jack as well as Trout, is made of Guttapercha, the size of (and I believe intended to represent) a small Roach, with pectoral flanges, and the tail rounded off; the tail, as the thing is commonly sold, being only in the way. This I have found very useful in some of the Scotch lochs, when short of natural bait. 
24 HALF-AN-HOUR WITH THE KILL-DEVIL. [PART I.

The first I ever tried was one of the old mother-o'-pearl sort, spinning from the tail; the water being the Wandle at Hackbridge near Carshalton. It was a brilliant morning in June when I turned out between four and five, and the mowers were just setting to work as I crossed the meadows. I began with the fly, but it was of no use. The water was like glass, not a cloud over the sun, and the weather-cock pointing to the North-east, though not a breath of wind was perceptible. Finding that I could not get a rise, I at length, from curiosity, put on the' kill-devil, which I happened to have in my book, to see how it would work. I at first threw into a small pool, an off-shoot from the river, just above the mill, where I should not have expected to find any fish at all. Instantly however I had one, a little chap of about a third of a pound. I put him back, and, not having had time to see the spinning of the bait, cast again into the same place. Again the result was the same, and again a third time, the fish being about the same size and duly returned. I then went to the river, and never before or since did I see anything like the effect of that bait. It seemed perfectly irresistible. No matter how I threw, (and I 
had only a fly-rod,)-no matter whether they saw me or not-they came at it as a hawk comes at a partridge and would not be denied. I put back again all the smaller ones, but, if my memory serves me, I kept two brace, of from about one to two and a half pounds. I was then told, after having been at it about half an hour, or less, that nothing but the fly was allowed, and of course left off at once.

Even in that short time however, I only just failed to rob the water of (in all probability) its principal ornament. While passing to the river below the mill from the pool where I first made trial of my bait, I dropped it into a deep dark pool fed by a back-water which poured down into it with a powerful stream through a slate-lined water-course set at a very considerable angle, and then drew it slowly up this water-course, just to see how it would spin in the rapid current, never dreaming of a fish. Suddenly, however, to my utter astonishment, out of the pool came after it with a rush, about ten feet up the water-course, an enormous brute, with a head like a bull. He got within an inch or two of the bait, when, either from seeing me so close to him, or from inability to stem the stream, he fell back, and of course I saw no more 
of him. Some time afterwards, happening to meet the owner of the water, I took the opportunity of apologizing to him for having unintentionally violated his rule restricting persons fishing it to the use of the fly, and incidentally mentioned the large Trout which I had thus seen and missed, when he told me that he knew him well, and that his weight was at least ten pounds, which was exactly what I had put him at.

Even in streams where the Trout run small the kill-devil is sometimes very effective.

I was fishing down the (Devonshire) Aron, between Cot and Gara Bridge, on the 16th of August, 1852, when the rirer was recovering from a flood, and apparently in good order for the fly. A determined rain from the South-west however prevented the fish from rising, and my basket shewed no more than about a dozen and a half Trout, all of them, with one or two exceptions, being mere sprats. Just before leaving off however, I met a young fellow, an attorney from Totnes, who had, with a kill-devil (one of those constructed to run up the line when a fish is struck) been having great sport, and half filled his basket with fish averaging near a quarter of a pound (large for Devonshire). He had one or two 
runs in every "stickle," and it seemed quite irresistible.

Two years ago, I put up a large coarse mothero'-pearl kill-devil (which Mr Gould had given me to see what I could make of it) to trail with when pulling up the (salt water) Loch Creran in Argyleshire. To my surprise the first thing I caught with it was a pretty good Sea Trout, which was succeeded by two or three Lythe (Pollack), Codlings, \&c. In salt-water lochs a piece of an old white glove sewn over a flight of hooks, of course leaving the hooks exposed, will be found to answer very well. It should be sewn in a round shape, so as to resemble a sand-eel as much as possible. If a piece of silver tinsel be twisted round it, so much the better. If sewn on one of the Archimedean bait tackles (those intended to be thrust into the mouths of baits, leaving the flanges exposed), it would, I doubt not, be more killing, as the flanges would give a little glitter to the bait, and the spinning of it would prevent the hooks from being so plainly seen. All artificial baits with pectoral flanges are, I think, preferable to those which spin from the tail. A piece of common tin-foil, such as tobacco is wrapped in, simply twisted round the hook, with a small 
piece left hanging loosely from it, will be found, when kept in motion, very attractive to Lythe, Cuddies, \&c.

The spoon-baits are, I believe, very good for Jack,-and Trout may also be killed with them. I have not, however, used them much myself, having rather a preference for the other descriptions that I have mentioned. A friend of mine tells me he has found that a drop or two of red sealing-wax dropped inside the spoons, makes them more enticing. It was, I think, $\mathrm{M}^{\mathrm{c}}$ Gowan, the fishingtackle maker in Bruton-street, (in whom, by the way, from his practical knowledge of the subject, confidence may be placed in matters connected with Salmon and Sea Trout fishing, who told me he knew of a case where a gentleman's valet in Scotland, one day when all the gentlemen of the party had gone down to the river for Salmon, himself went out on a lake adjoining the house, trailing a spoon-bait, and surprised them, on their return with empty creels, by exhibiting two clean Salmon which he had caught there with it.

It will be well worth the while of any one who may be going on a fishing excursion where there are pieces of water stocked with Jack, to put up, with his fishing-tackle, two or three of the India- 
rubber balls which are capable of being inflated at pleasure, and are sold as toys. They take up no room, and answer very well for floating off livebaits with. If there is a boat on the water, they need not be fastened to the shore. If not, it will be generally necessary to have them made fast to a line, which should be kept from sinking by a few small corks attached to it at intervals. The balls should be more or less inflated in proportion as there is less or more wind. By shifting the position of the end of the line on shore, the greater part of the water can thus in most cases be closely fished.

Jack will often, if not hungry, take a live bait apparently for mere wantonness, and, after holding it for a short time, leave it again. When this is the case it "sells" them considerably to fish with a double set of tackle, each consisting of a baithook and another rather larger one tied just below it back to back, the two sets being on different pieces of gimp meeting the line about eight or ten inches from the bait at a swivel, just above which the lead may be fastened. One of the bait-hooks should be run through the skin a little before the tail, the other just before the dorsal fin, so that the loose hooks stand out on opposite sides. This 
30 DOUBLE LIVE-BAI'T TACKLE FOR JACK. [PART I. way of fishing makes you quite free of the Jack's fancies, as you can strike at once, the double set

Fig. 5.

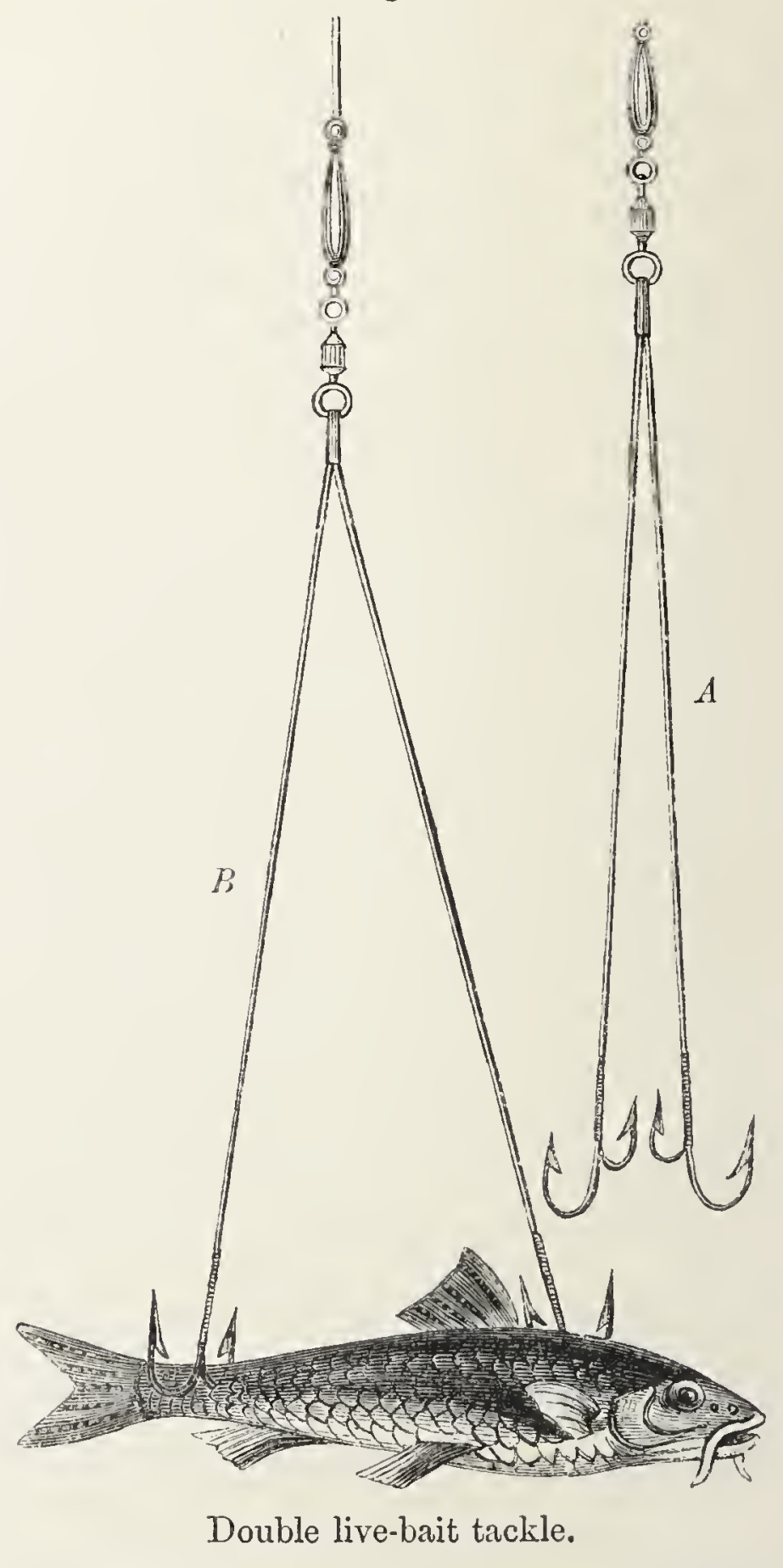

of hooks rendering you "in utrumque paratum." The cuts in Fig. 5 will exemplify my meaning,- 
CH. II.] "GAG AND EXECUTIONER" FOR JACK. 31

$A$ being the tackle without a bait on; $B$ the same ready for action.

A Gag for keeping open the mouths of Jack whilst you are disengaging the hooks will be found very convenient, and often save both your time and finger's. Such a one as that represented in Fig. 6 has the double merit of being very simple and answering perfectly. It should be made of thickish hoop-iron, and about nine or ten inches long. In using it the lower (moveable) jaw should

Fig. 6.

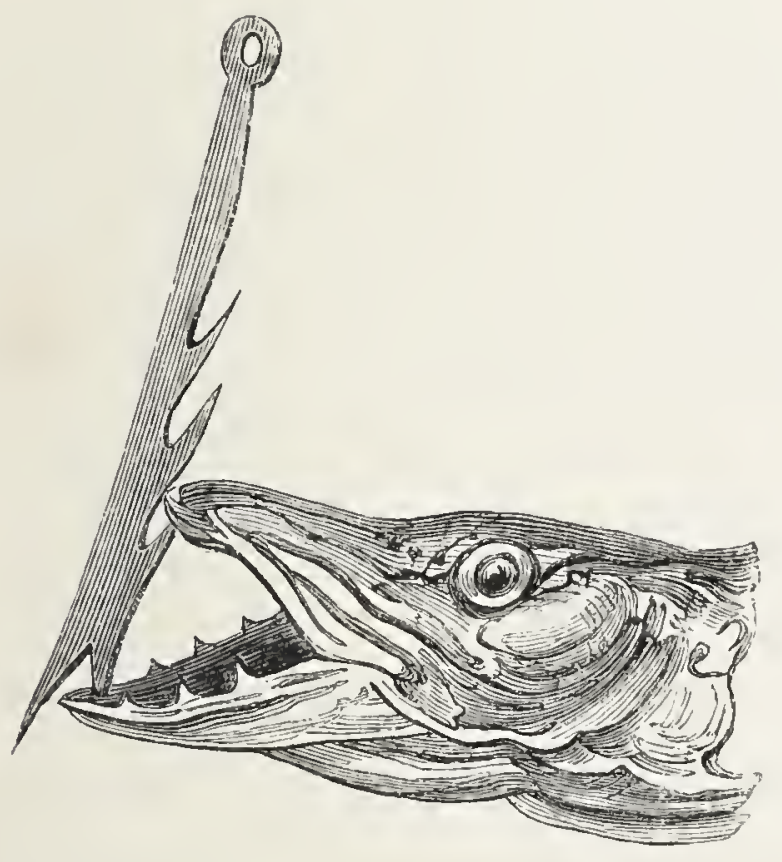

Gag for Jack.

be forced down with the point farthest from the handle. If made tolerably heavy at the lower end, it also answers very well as an "executioner," wherewith to administer the coup de grace. 
Whilst on the subject of dodges, I may mention the following simple and ingenious one for "live-ground-baiting," (if it may be so called,) which has been lately hit upon by a friend of mine, and practised by him with considerable success, several good Thames Trout, which had been proof against every other temptation, having at length yielded to it.

Above the bait-hook, which is simply passed through the upper lip of a live Bleak, he fastens one or two bob-flies tied on straight pieces of wire, or hooks minus the bends.

The live bait is then quietly dropped in as near the Trout's haunt as it can be ascertained, and the bob-flies kept in motion on the surface of the water. These naturally attract the neighbouring Bleak, the old Trout all the time watching their movements from his hiding-place. At length, when a number have been thus collected, he can stand it no longer, and makes a dash at them. Away they go instanter, none remaining but the unfortunate individual on the hook, who is forthwith bolted. The presence of the free Bleak would probably be sufficient to disarm the suspicions of the most wily Trout. 


\section{CHAPTER III.}

How to catch Carp-Tame Carp-Carp basking-Grasshopper bait-Carp, Eels, and Eschylus-Fish-ponds near Brussels-Great Carp caught in them-General management of fish there-Growth of fish promoted by change of water-Effect on Jack-on Roach-Noises made by Carp at night-Spawning of Carp-Their spawn devoured by water-birds and fish-Dace caught with Spinning-bait_Carp with live Minnow-Eel with FlyPerch with Fly. $\mathbf{M}_{\text {they say, are so shy that it is of no use to }}^{\text {ANY people have Carp in their ponds, which, }}$ fish for them. Should you hear of such a case, and, having nothing better to do, like to volunteer your services, I think that, (should they be accepted,) you will, by adopting the following plan, meet with sufficient sport to induce you to repeat your visit.

The tackle required will be simply a long rod, a reel containing not less than fifty yards of fineish line (though less will do if the fish run small), a fine but sound casting-line, nearly as long as the rod, hooks of about No. 9 size, tied on gut to match, and a small unpretending-looking float; besides a good lump of the crumb of new 
bread, and a landing-net. Having looked out a quiet place in the pond, selecting rather shallow than deep water (particularly if the weather be at all hot, when Carp always affect the shallows), and, if the pond be a large one, and cattle have access to it, not very far from that part where they come to drink, gently stick into the ground near the edge a small forked stick (the fork about two feet above ground), to rest the rod upon and keep it clear of the water, and also a few small bushes to screen you from the Carp. Then, after quietly plumbing the depth of the water you intend to fish, cover the whole of your hook, shank and all, with a plummet-shaped piece of bread, kneaded into paste (remembering that, if the slightest part of the hook is visible, not a Carp will touch it), and, setting the float two or three feet further from the bait than the depth of water, throw it well out, drawing in afterwards all the slack of your line. You may then lay down your rod, resting the top upon the forked stick, and disposing the line so that it will run out freely; and, sitting down, while you smoke your pipe, if you like, proceed to ground-bait the place by filliping in bread-pills all round your bait and pretty wide of it. The 
two great objects should be, not to alarm the Carp, and to get them to feed. They are very timid, and if they have once taken fright at anything, and left a place in consequence, it will generally be a good while before they will return to it. For this reason I prefer not to throw in any ground-bait when fishing for them, until all my preparations are made, and the actual bait is in the water. If you can once induce them to begin to feed, they will continue their search for food in every direction, and infallibly in due time come to your bait. When they begin to come to the bread, if the bottom is at all muddy, and the water not too deep, you will see lines of mud stirred up by them as they come on nuzzling in it like so many pigs. You have then only to keep perfectly quiet and bide your time. The float will give you sufficient warning when to strike, and you should only do so when the Carp is going well and steadily away with it. If your tackle is sound, and you are not in too great a hurry, you may make pretty sure of landing him, for, as Izaak Walton truly says, "The Carp is a leather-mouthed fish, which doth seldom break his hold."

Although I think it better, for fear of alarm- 
ing the fish, not to throw in any ground-bait, until the actual bait is ready, yet I am far from saying that general ground-baiting in the place where you intend to fish is a bad plan. On the contrary, the more you feed in a particular place, the more certain will the Carp be to resort to it, and, by constantly doing so, you may get them to become nearly or quite as tame as barn-door fowls. I may instance those in the pond of the garden attached to the Kursaal at Wiesbaden, which are really a curious sight. Much more interest and amusement is to be derived from Carp than people in general are at all aware of:it seems a pity that they should. be so neglected as they are in England.

When Carp are basking on the surface of the water, they can scarcely ever be induced to take a bait; nevertheless, if feeding is going on at the bottom, they before very long by some mysterious sense become aware of it, and will wake up and "go below to dine." But though you cannot catch them with a bait, while thus basking, yet you may occasionally do so without one, by lightly throwing over and foul-hooking them. This plan, with a large weighted treble hook, is sometimes adopted with destructive effect 
by poachers for salmon when lying at the bottom in rivers:-it is then called "stroke-hauling."

Grasshoppers, two put on back to back, form by no means a bad bait for Carp late in the summer, but then they should be suspended by the float about four or five inches from the bottom, if possible, near some weeds or water-lilies, and not rery far from the bank. I was at home one Long Vacation, when I supposed myself to be reading Aschylus, inter alia. This I performed by taking down to a summer-house, adjoining a pond well-stocked with Carp, in one hand my Aschylus and Lexicon, and in the other a couple of rods all ready for action. These latter I laid in duly baited with grasshoppers (for I had not then discovered the bread-dodge), and retired to the summer-house, returning to risit them after each hundred lines had been got through. That was, at least, the rule I proposed to myself, but I suspect I looked up occasionally before I got to the end of the hundred, and, if I saw the top of a rod bending, did not make a point of waiting to finish them. Besides the rods I had also some half-dozen night-lines set, baited with worms for eels, which I visited periodically-I think at the end of each scene. What 
38 FISII-PONDS NEAR BRUSSELS-GREAT CARP. [PART I.

was the amount of Aschylus that I got through under the circumstances I cannot undertake to say, but I remember I had very good sport as far as Carp and Eels went.

Worms are, I fancy, a better bait for Carp early in the season, than later.

The weight of the largest Carp mentioned by Yarrell is nineteen pounds and a half, but abroad, if not in England, they occasionally attain a much greater size.

Mr Maltby, our Vice-Consul at Brussels, has within the last few years taken out of some pieces of water, rented by him in the neighbourhood of that city, Carp weighing no less than thirty-three pounds; and a friend of mine was present when, in February of last year (1859), some twenty Carp were taken from one of them, which ran from about twenty up to twenty-five pounds each. He endeavoured to bring five of the largest alive to England with him, but, unluckily, from some restrictions on the French line as to the carriage of live produce, he was obliged, after taking them a considerable distance, to send them back to Ostend, before reaching which they died.

Through the courtesy of Mr Maltby, who appears to have considered the subject of breeding 
CH. III.] MANAGEMENT OF FISH BY MIR MALTBY. 39

and rearing fish with a degree of attention rarely bestowed on it, I am enabled to give the mode adopted by him in the management of his fish, together with some otluer details connected with it, which cannot, I think, fail to be generally interesting.

The pieces of water rented by him are five in number, namely, La Hulpe, a lake about twenty acres in extent; Boilsfut, a lake of about seven acres, five miles from La Hulpe; and three others of about an acre each; these last being fed by small independent streams and springs, the water from which finds its way into the larger one, Boilsfut. In this the fish increase rapidly in weight, and their quality is precisely the same as that of river-fish, although it contains no gravel or stones, and a considerable quantity of mud is contimually deposited in it; the numerous streams flowing into it, and the great head of water always kept up (to supply a large mill, which is at work below it the whole year through), being the probable causes of their doing so well there.

All these waters are however so cold, that, except in favourable seasons, the Carp rarely breed in them to any extent, one year only, out 
of about every four, yielding a supply sufficient to maintain, unaided, an adequate stock. To obviate this difficulty $\mathrm{Mr}$ Maltby purchases the stores of Carp requisite to keep up his supply, when they are two years old, the weight of each being then from two to four ounces, and their price thirteen to fourteen francs a hundred. These he puts into one of the three smaller ponds, and allows them to remain there for a year, by which time they have attained to about three-quarters of a pound each. They being then rather too large mouthfuls for ordinary sized Jack, he transfers them to one of the larger pieces of water, either La Hulpe or Boilsfut. After having been a year in these new quarters they are found to have increased in weight from three-quarters of a pound to from two pounds and a half to three pounds and a half each, according to the health of the individual fish; - there being in fact no extraordinary increase in the weight of Carp until they are three years old, when they progress rapidly, until they attain that of about six pounds. After that they do not appear to continue to do so in a similar ratio. Those of the largest size mentioned, twenty-five and thirty-three pounds, he considers to have been about fifteen or twenty years old; having how- 
CH. III.] CHANGE OF WATER-MODE OF TRANSPORT. 41

ever purchased them when he became tenant of the waters, he is unable to speak positively as to their ages. He describes them as being very handsome, and invaluable for breeding purposes, though, for the reason above mentioned, he is unable to rely exclusively on them for his stock.

Although both lakes, La Hulpe and Boilsfut, are fairly well supplied by springs and natural streams, yet he believes the qualities of the waters flowing through them to be different, the sources from which they are derived being distinct.

With a view therefore of promoting the growth of his fish-a change of water being in his opinion the means which, more than any other, conduce to improve both their size and quality-he every other year transports the smaller fish from Boilsfut to La Hulpe, and vice versa. This he effects by carting them across in barrels, the proportion of water to fish in each being one-third water and two-thirds fish. In order to insure them a due supply of air during the transit, the hole in the side of each barrel is bunged up with a wisp of straw. By the jolting of the cart the fish are kept in continual motion, and, while the water is prevented from escaping, it becomes, by being shaken against the straw, sufficiently charged with 
external air for the purpose of respiration. By adopting this mode of carriage he never loses five pounds weight out of three thousand pounds transported.

The effect which such a change has upon Jack appears to be most remarkable, the increase in their weight, after removal, being in some cases, at the rate of not less than from eight to ten pounds a year. In the year 1856, for instance, $\mathrm{Mr}$ Maltby marked and transferred from the large lake of Boilsfut to that of La Hulpe, forty-five Jack, averaging one with another two pounds each; none of them weighing more than three pounds. In eighteen months from the time when they had been thus transferred, many of these same fish were caught by trolling, having attained the weight of from fifteen to twenty pounds, being at the extraordinary rate above mentioned.

This increase in the size of the Jack was so sudden and unexpected, that nearly all the smaller fish were destroyed by them, before any steps could be taken for their removal. It was however then effected by letting out the water, when the Jack were placed in one of the smaller ponds above mentioned. In this however, although it 
CH. III.] DESTRUCTION CAUSED BY LARGE JACK. 43

contained a good supply of white fish, they rather lost than gained weight, probably, as Mr Maltby imagines, in consequence of there being a smaller body of water ruming through it, and that colder, from being nearer the source.

At the commencement of the year 1857, he had purchased and turned into the Lake at Boilsfut nine hundred Carp of a particularly good breed, weighing, one with another, a pound each; but of these, when the water was let out in the month of October, not a single one was to be found, the Jack not having suffered a solitary individual to escape them. Since that time Mr Maltby has allowed no Jack to be put into his water, as stock, above a pound in weight, which (as younger fish do not gain weight so fast,) will not increase in a year to more than about three or four pounds. It is only after attaining that weight that their growth becomes so astonishingly rapid.

In the Lake at Boilsfut, Jack, Perch, and white fish breed fast, but the fish born in that Lake do not increase so fast by two-thirds as those born in La Hulpe; so that, although their transport from the one to the other is expensive, yet it is made up for by the increase of weight in the fish transported. 
Perch do not appear to grow to a large size in his waters, not running commonly to more than a pound weight, although, from the large number taken with rod and line, as much sometimes as forty pounds weight to a single rod in a day, they may scarcely have a fair chance of obtaining their full dimensions. Thinking however that his breed is an indifferent one, Mr Maltby has crossed it with some from the Meuse, by which he hopes to improve it. Similarly, with a view of improving his breed of Carp, he has imported some from the Rhine, whereby he has already obtained a very handsome cross in point of shape and colour, besides an actual improvement in the quality of the fish.

Every year, or every two year's, he has a sale of his fish, as well to cover rent and current expenses, as because he gains nothing on large fish, these not being marketable.

The profit made is upon those which weigh three quarters of a pound when put in, and from two pounds and a half to three pounds and a half when taken out, so that he only saves such fish, above those weights, as are peculiarly handsome in sliape and colour. The whole of his waters, collectively, thus contain (with the exception of 
the very large ones) perhaps not more than a hundred weighing above six pounds. But to give an idea of the number of fish in them, he considers that on a favourable day in April a single rod may calculate upon catching from a hundred to a hundred and fifty pounds weight of Carp.

Tench he finds to be very slow growers, and he has a difficulty in ascertaining what water suits them best. One year he had them up to two pounds, but they were so much sought after, that he was induced to allow all the best to be sold, and there are now not many of above a pound. The last has been an unusually favourable breeding season for them, and at least ten thousand have been thus added to his stock. He considers them, for the table, by far the best fish in his waters, being firm and full flavoured, without the least taint of mud, so much so indeed that they are found to be better plainboiled than dressed in any other way. The Carp are also extremely good in quality, having a curd like Salmon, and their condition, when in season, being such, that the under side of one of four or five pounds ordinarily exhibits a coating of fat perhaps a quarter of an inch in thickness.

There can surely be no reason why breeds of 
46 GROWTH PROMOTED BY CHANGE OF WATER. [PART I.

fish should not, by selection, proper management, and feeding, be susceptible of improvement, just as much as those of cattle, sheep, or poultry: all that is required to insure it is doubtless careful attention combined with a discriminating judgment, such as Mr Maltby has brought to bear upon the subject. It is much to be hoped that it may be taken up by others who have time and opportunities for prosecuting it, and that, stimulated by his example, and encouraged by his success, they will be induced to persevere, until they have shewn that the many thousand acres occupied by now umprofitable ponds, may be made to return as good, if not (as I believe may be the case) a better rate of interest, than the land surrounding them.

The following incident occurs to me as decidedly tending to confirm Mr Maltby's observation, that the growth of fish is, under certain circumstances, much promoted by their transfer from one piece of water to another.

In a pond, the Roach in which were very numerous, and ran generally from about four to six inches in length, a friend and I one morning, just at the close of the hay-harvest-throwing a worm fly-fashion, and drawing it in very slowly- 
caught, to our great surprise, some twenty or thirty, weighing one with another nearly or quite a pound each.

We were altogether at a loss to understand what could have led to their attaining this unusual size, until we found that about that number, which had been taken out of another pond, and afterwards for some time incarcerated in a tank in the stable-yard, had been turned in there. The change from the short commons on which they had been kept in the tank, to the more liberal fare furnished by their new quarters, added to the fact that the pond, from being of comparatively recent construction, afforded an extra supply of food, had doubtless been the simple causes to which this increase in their growth was attributable.

Besides these Roach and a quantity of others of the ordinary size, we also caught the same day as many, I think, as eight or ten carp, weighing perhaps three to five pounds each, some eels, and (unintentionally) two or three Trout, (part of a lot which had been recently introduced,) so that that morning's work is impressed on my memory as altogether about the most productive bit of pondfishing that I ever had.

The Trout, which it was hoped might have 
become naturalized in the pond, gradually succumbed, as usual, to the muddiness of the water caused by the Carp, it being from that cause almost an impossibility to get the two to do well together, unless the piece of water in which they are placed have, rumning through it, a stream sufficiently strong to carry off the mud.

It would seem, strange to say, that we that day caught every one of the large Roach which the pond contained. At least, I believe that never since-and that must be now some twelve or fifteen years ago-has a single one approaching their size been taken out of it.

If on a fine calm summer night you visit a piece of water well stocked with Carp, especially if its sides be perpendicular and faced with brick, and the fish be numerous in proportion to the feed, you will probably hear every now and then a long-drawn sucking noise, followed by one as of blowing. These are occasionally so loud and striking, that although I imagined them to proceed from Carp, yet I could scarcely persuade myself that such was the case, until I had lain down on the grass, and succeeded in touching them with my hand whilst in the very act of producing them. They are, I have no doubt, ascribable to the 
Carp's habit, while "priming" along the edges of ponds at night, of sucking in from the interstices amongst the bricks, \&c., any insects which may be lurking there, and which he could not otherwise get within reach of his mouth, and afterwards rejecting any substances which may not suit him, all "between wind and water," as a sailor" would say. The fact that these noises are louder, more prolonged, and more frequent in a pond faced with brickwork, than in one the sides of which slope off gradually and present a comparatively even surface, seems to lead to this conclusion. When feeding Carp with bread, you may often see this power of suction exercised by one as he rises almost perpendicularly under a piece floating on the surface, and draws it down in a little vortex to his scarcely visible mouth, which, by the way, is thus enabled to take in much larger morsels than it otherwise could. A few minutes' close inspection of gold fish in an aquarium will shew the same process of indraught and expulsion continually in operation.

I have no doubt that, owing to this habit of the Carp in thus priming along the sides of ponds at night, a night-line set with the bait hung on the surface of the water, close to the edge, would be a 
very killing dodge for them. It might be fastened on a "bank-runner."

Having noted, for some years, the days when the Carp were spawning in several ponds in the Isle of Wight, I find, on comparing my notes on the subject, the earliest of these days to have been the 19th of May, the latest the 3rd of July. The time of spawning seems to depend much on the mildness or backwardness of the spring, and also on the position of the water, the Carp being always earlier in a mild than in a cold season, and also earlier in sheltered ponds than in those which are exposed to currents of wind, and where the water is colder, in consequence of its depth, or the influx of a spring. I have, for instance, found the Carp spawning in the same pond as early, after a mild spring, as the 30th of May, and, after a backward one, as late as the 1st of July; and, again, in the same year I have seen them spawning, in a sheltered pond, on the 19th of May, and, in a comparatively exposed and deep one, on the 1st of July, the ponds being supplied by the same run of water and only about a third of a mile apart, the lower of the two being the earlier. My observations would lead me to conclude that the process of spawning, with Carp, does not generally 
CH. III.] SPAWN DEVOURED BY BIRDS AND FISH. 51

occupy more than a couple of days, and that it is often performed in one. There are, however, occasional exceptions, as $I$ have seen it going on in the same pond on the 3rd of June, and again on the 9 th of the same month.

There can be no doubt that (in shallow ponds particularly) a great part of the spawn is devoured by water-birds, and that small fish, Roach for instance, are also very destructive to it. Having one day, after watching the Carp spawning, taken up a position in a summer-house hard by, I saw fiy into the pond four Mallards, which within a minute or two were busily engaged with their heads under water exactly where I had seen the Carp. In a very short time they were joined by a Moor-hen, who also immediately went eagerly to work at the same place.

I had at one time, by constantly feeding the Roach in one of these ponds, brought them to such a degree of tameness, that they would take bread out of my fingers, and play round and through them in scores. Generally they were collected in numbers waiting to be fed at their accustomed breakfast-time, but I noticed that, while the Carp were engaged in spawning, only two or three made their appearance, and even they would scarcely 
look at the bread which I offered them, being doubtless gorged with Carp-spawn. I have indeed not unfrequently detected them apparently in the very act, observing them at intervals dashing rapidly about, close in the wake of Carp which were engaged in spawning. But if Roach do, as I think there can be no doubt, thus make free with the spawn of Carp, yet I suspect they are useful to the parent fish in relieving them from water-lice, with which they are occasionally much infested. This suspicion is grounded on the fact that having seen Carp on the surface, with Roach swarming closely round them, and, on several occasions, by foulhooking or otherwise, managed to take them from out of the middle of such company, I invariably found them to be suffering from these parasites. When in this state they rapidly lose condition, and sometimes become so poor and weak that they will suffer themselves to be taken out of the water with the hand.

I know of two instances where Dace have been caught with a spinning-bait, not hooked foul, but fairly in the mouth. One of these was by $\mathrm{Mr}$ Gould, the fishing-tackle maker, in the Colne: the other by a brother of mine in a piece of water in Hampshire; the bait in the 
CH. III.] CARP WITH MINNOW-EEL WITH FLY. 53

latter case being a German-silver kill-devil, and the Dace not above six or seven inches in length. But a friend of mine, a good fisherman, and whose word cannot be doubted, assures me that he did a much more extraordinary thing, having, whilst fishing in the Canal near. Waverley Abbey, Hants, actually caught with a live minnow a Carp weighing about three quarters of a pound.

The Dace were probably allured by the glitter of the bait, and may have taken it for sport, or to ascertain what it was,-for I apprehend that they never really feed upon small fry; but the Carp must have taken the minnow deliberately, and, from that circumstance, I should conclude that they do occasionally, either when pressed by hunger, or from a morbid appetite, take a minnow or so by way of a change.

I once caught an Eel with a fly. This however sounds so very extraordinary, that, in order to save my character for veracity, I must mention the circumstances under which it occurred. I had been fishing in a pond for Roach with the natural fly, when, inhospitably wishing to "shirk" a party of visitors whom I saw driving up to the house by an approach which commanded my position, I put down my rod, leaving the fly in the water. 
On my return I found it had been gorged by an Eel, not a large one, but still quite large enough to swear by.

It is pretty generally known that Perch will occasionally take a fly. Although they will rarely do so in rivers, yet in ponds not only is such a circumstance not of unfrequent occurrence, but the fly is actually sometimes one of the best baits that can be used for them. As a proof of this, a friend of mine one day caught in this way in Little Frencham Pond, not far from Farnham, sixty-five Perch averaging about a pound each; and on the same day, another rod, also fishing with the fly-a brightish one, such as you would use for Sea-Trout-caught there between eighty and ninety pounds weight of Perch, besides a Jack of about six pounds. 


\section{CHAPTER IV.}

In selection of Flies, colour, not form-Old rule, "Light fly for darkness," \&c. rather to be reversed-Fastening for Casting-line-Ditto for Bob-fies-Make-shift Gaff-Cutand-thrust Rod-spear-Simple Clearing-line-Fastening for loose Reel-Fish slowly with Fly-Straight lineHair casting-lines-Tailing fly with "Gentle"-Fishing near Genera-Versoix-Ean de Lyon-Lines on Versoix -In Trailing, side next sleore best--In Sea-fishing, stern of boat better than bow.

AM persuaded that for fly-fishing colour, not 1 form, is the principal thing to be looked to in the selection of flies. This scarcely any one can doubt who has seen-perhaps with a feeling akin to envy-the advantage which a provincial furnished with coarse tackle and the roughest home-made flies has on a river which he knows, over another (possibly a better fisherman) who comes to it elaborately equipped, and with his book stored with the choicest specimens of Bowness' art, but ignorant of the exact colour to adopt. Had I wanted a convincing proof of this, it was afforded me some years ago whilst fishing 
the Aron near Cot in Devonshire. I had up as a bob a small greyish-brown palmer made by one Godden at Whitchurch in Hampshire, and finding that the Trout evinced a decided preference for this, I put up another as a stretcher, tied by him at the same time and to the same pattern, and, so far as I could see, exactly similar to it. They would not however look at this one, but continued taking the other freely, even after it was chewed to ribbons-the hackle unwound, and hanging an inch below the hook-until at last, in consequence of the silk following its example, I was obliged to discard the fly altogether. I replaced it with another of the same lot, but the great attraction was gone. Besides proving their penchant for a particular shade of colour and their indifference to mere form, this incident also shews the great nicety of sight possessed by Trout. On this occasion, out of two and a half dozen which I caught whilst I had these palmers up, at least two dozen and two fell to the share of the favourite bob.

If the old rule of "a light fly for darkness and a dark fly for lightness" be ever at all correct, I think it can only be applicable to night-fishing, as I have certainly more frequently found the 
CI. IV.] "LIGHT Fly FOR LightNess:" QU.? 57 converse to hold good during the day. There are, however, doubtless occasional exceptions, such for instance as the yellow cow-dung fly, which I have found a great killer on a stormy day, particularly among meadows, where the natural fly would abound, and when it would be swept off upon the water.

On "stickles" (the expressive Devonshire word for the broken water at the head of pools) I think I have generally found a small bright fly (yellow floss-silk body and starling wing, for instance) kill better than a larger sombre one, but the latter to answer better in the still dark pools. This, which I have noticed quite independently of the last theory, certainly tends to support it, as Trout, in common with most fresh-water fish, undoubtedly lie upon the shallows when the weather is bright and hot, and retire to the deeper water as it becomes cold and gloomy. It is for the same reason, as I believe, that Trout do not, in hot weather, so much affect those parts of a river which are densely wooded, and consequently shaded, as those which lie open and exposed to the sun. A red fly I have always found kill better rather late in the evening than at any other time of the day. In the white-moth tribe, as night-flies, 
I have not much faith, though I have heard of their doing good service; - when they do answer, I imagine it is only on very warm evenings.

Let me recommend those, who have been in the habit of fastening their casting-line to the line by a loop on each, to adopt the much better plan of having merely a knot at the end of the line and a loop in the casting-line. They are then most easily fastened by just passing the knotted line through the loop, giving it one turn round it, and then bringing it back again between the loop and the line as in Fig. 7, after which the latter is pulled down to the knot. This mode of fastening relieves you from the nuisance of having to pass all your casting-line through the loop, and often saves much trouble if you happen to get hung up. It possesses also the decided advantage of rendering your line lighter to cast with.

As a mode of fastening bob-flies to the casting-line I find the following much the best and most serviceable that I have ever tried, combining, as it does, the three great essentials of strength, lightness, and general convenience. The 
casting-line should be cut at the place where you wish the bob-fly to be attached, and the two ends placed overlapping one another. With each end (previously well soaked) you make a simple knot round the adjacent part of the casting-line, and draw them moderately tight. Then, having previously cut the gut attached to the bob-fly to the proper length, and tied a knot in it to prevent it from slipping, you insert the knotted end between the two pieces of the casting-line which lie between the knots, and give it a single turn round one of them. Then just draw these knots together. Pull down the gut of the bob-fly to the knot in it. Wet the knots once more in your mouth to make assurance doubly sure; pull each of those on the casting-line quite tight, and then the two firmly together. It is now complete. When clipping off the ends of the gut however remember to leave about a sixteenth of an inch projecting beyond each of the two knots in the casting-line. Should you wish to change your fly, you can then, taking hold of one end with your teeth and the other with a small pair of pliers, which no fly-book should be without, pull them apart, take out your fly, put in another, and draw them together again. This fastening, before 
the knots in the casting-line are drawn together, will appear thus.

Fig. S.

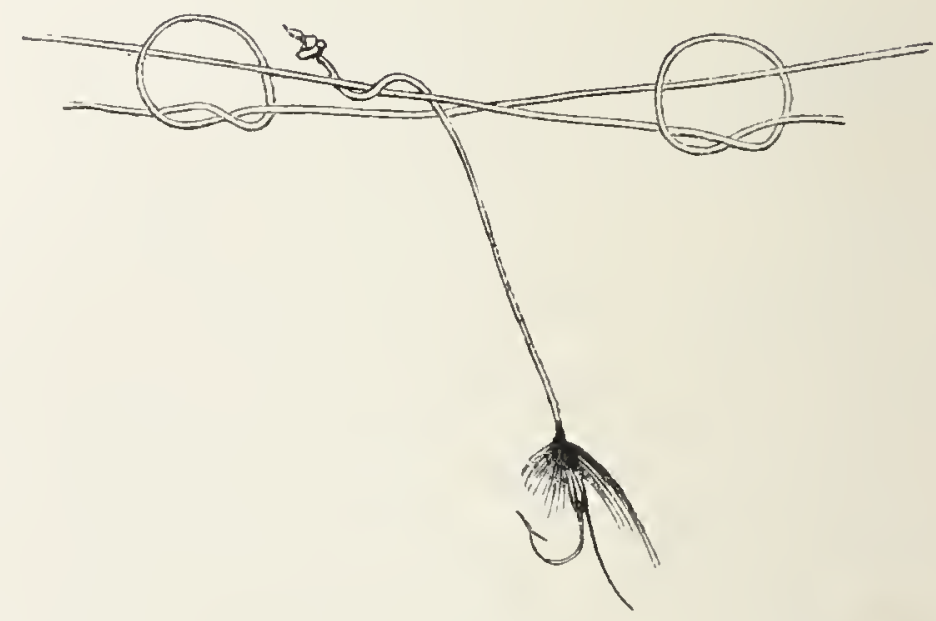

Fastening for Bob-flies.

I always, in making up my own casting-lines, use this description of knot throughout, finding it (so far as my experience goes) less likely to slip than any other. It may appear somewhat complicated at first sight, but will be found very simple in practice.

The following substitute for a gaff will be found to answer sufficiently well on a pinch, and save you the trouble of carrying about a regular gaff, when it may be inconvenient to do so. Whip any large, long-shanked hook on to a piece of string about five feet long, commencing at the bend and fastening off half-way up the shank, 
CH. IV.] CUT-AND-THRUST ROD-SPEAR.

leaving the other half bare. Thrust this bare end into the pith of an elder or withy stick about four feet in length, which you can cut when likely to want it, and, after giving the string two or three turns round the stick, bring it up to your hand, having previously made a loop in the end to hold it by. The act of striking a fish will bring the gaff out of the stick, which you may drop altogether, the line on it being quite sufficient to land him with.

A rod-spear made on the principle of the annexed drawing, to cut and thrust, may not unFig. 9.

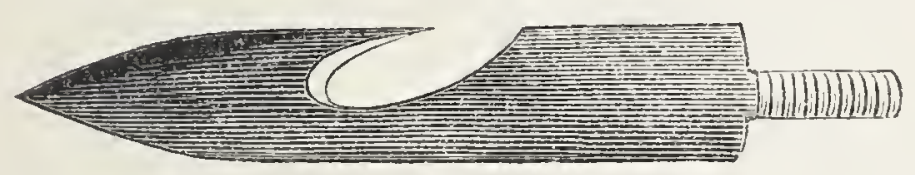

Cut-and-thrust Rod-spear.

frequently be found of service for cutting away twigs or weeds in which your fly has got entangled, they being often just too far for the fisherman to reach with the ordinary appliances at hand. Many a good fish has been lost for want of such a thing, and that in the most aggravating way possible, when quite exhausted and all but within reach of the net, by the bobfly getting hung up. 
A simple method of clearing your line, when otherwise "in trouble" is to fasten a stone to a piece of stout string, which should be always carried in the fishing-basket, and then, pitching the stone over the offending branch or weeds, haul away at the string. This expedient will often set you free at once, and save a deal of bother.

When fishing with a rod to which there is no convenience for fastening the reel, a piece of leather wetted and put under the reel before it is tied on, will be found sufficient to keep it from slipping. When the straight piece of brass under the reel is too small for the hollow made to receive it in the rod, a slight bend given downwards to the brass, which can generally be done with the hand, will, on an emergency, be found to make it fit sufficiently tight for use.

My experience leads me to believe that-whether using the fly or spinning-it is, if your tackle is fine, a great mistake to fish too fast. The act of drawing the fly along rapidly imparts to it an unnatural motion,-for when did a Trout ever see a fly propelling itself rapidly under water? Besides this it must have a tendency to bring the fly to the surface, when it leaves a wake behind 
it which cannot but frighten the fish. Although small fish will take a fly under such circumstances, as, like kittens, they will run at almost anything which passes rapidly by them, yet it is rarely that a steady old Trout can be induced to do so. It is even more essential, when fishing with a "dry fly," to leave it almost entirely to its own devices, as it will thus float much longer than it would if interfered with, and its movements unnaturally hastened. These observations do not apply with equal force to the bob-fly, which, traversing the surface of the water (as its name implies) with a succession of dips or bobs, might be taken by Trout for the natural insect. Steady fishing will however be found more successful even with the bob-fly. In casting generally, straightness of line is in my opinion the first point to be aimed at, and lightness the second. Both however are most essential. It should be a rule never to fish with a yard more line than is absolutely necessary.

In some very fine, clear water, Trout can be taken with a hair casting-line, when it would be almost useless to fish with one of gut. I found this to be the case on the Wharfe, where the tackle ordinarily used consists of a hair casting- 
line and five or six diminutive flies also tied on hair, and where I was told it would be lost labour to try gut. I was rather sceptical on the point, and tried fine gut, but soon had to resign it in favour of hair, when I found an immediate and striking difference. Where the water is clear, it may, I am persuaded, be often used to great advantage. It is somewhat troublesome to fish with, inasmuch as it requires great care in its use; -for, if you get hung up slightly, and clear yourself without a breakage or apparent mischief, yet perhaps the hair will start at a knot in consequence of the strain and come asunder a minute or two afterwards at the slightest touch. It is however astonishing, if the pull be a steady one, how much it will bear.

When the water is very clear and bright, Trout will sometimes take the fly freely if tailed with a gentle, while they will not touch it without. A friend of mine, then residing at Geneva, and one of the best fishermen I ever knew, who used to catch a good many Trout in the neighbouring streams, considered it useless to go out when the water was in that state, unless he was provided with a supply of "fruit," as he called them. No one would probably take advantage of 
CH. IV.] STREAMS NEAR GENEVA-VERSOIX.

this dodge, unless driven to extremity, when it surely may be permissible. One calm bright day, when the water was very clear, I had been whipping a loch in Argyleshire with scarce any success, when I happened to see something depending from the brim of my wide-awake. On taking it off, I discovered that the object was a white caterpillar, and, remembering this dodge, immediately availed myself of his volunteered services, by tailing my fly with him, the result being a good sea-trout the very first cast.

Having casually alluded to Geneva, I may mention that there are two good fishing-streams within reach of it. One, the Versoix, rising in the slopes of the Jura, and flowing into the Lake about seven miles above Geneva, is a charming bright, lively stream, running through very pretty scenery, rather wooded in some places, but in others fairly open and easy to fish. Though Trout are not very abundant in it, yet they are some of the most beautiful, as well as the best for the table, that I ever came across. They run occasionally up to two or three pounds,-a miller indeed caught one of between six and seren pounds in his mill-tail-and enough can generally be met with to make it quite worth while to try for them. 
The scenery however would alone quite repay the fisherman. The other stream, the "Eau de Lyon," or "London" (as it is sometimes called), joins the Rhone about twelve miles below Geneva. This, also flowing from the Jura in a clear stream, runs, for some miles above the river, through an open country, mostly clothed with juniper, and nearly the whole of it can be, thus far, easily commanded. It abounds with Trout and Grayling, but the Trout do not generally run so large there as in the Versoix.

The following lines-a well-merited tribute to the charms of the Versoix-were sent me by a friend, with whom I had passed some long-to-beremembered days by its banks.

\section{VERSOIX.}

Aye! many a pleasant day was ours

Where the crystal Versoix ran

To end its brief, pure, glittering course

In the bosom of blue Leman.

There was joy in the fresh clear dawn of day,

There was joy in the glowing noon,

And a deeper joy in our homeward way

By the light of the quiet moon.

There was joy in the path 'neath the old oaks' shade, Through the wood so calm and cool;

There was joy in the roar of the far eascade,

There was joy in the deep still pool. 
CH. IV.] SHORE-SIDE BEST IN TRAILING.

And long may it run, for a sweeter stream

Never fisher nor painter saw,

And merrier Trout never leapt in the beam

Than the Trout of the swift Versoix.

When trailing a bait in lakes, the side next the shore will almost invariably afford the best sport. The same remark applies to rivers, when trailing from a boat. When from a punt however-that being commonly worked close along the bank-the case is of course different, as the fish, which are lying under its shelter, are thus naturally disturbed and driven into deeper water.

In sea-fishing, those in the stern of the boat will generally be found to have better sport than those in the bow. That this is the case I have little doubt, it having been often remarked by others as well as myself. As to the reason why it should be so, I have a difficulty in arriving at a satisfactory conclusion. I used to imagine that, as the scent of the baits would be carried down with the tide, the fish below, becoming sensible of it, and following it up, would naturally arrive first at the baits from the stern. But this theory was shaken whilst I was fishing one blustery day on a Scotch loch. On that occasion the wind was stronger than the tide, and the boat consequently swung 
stern to the current. This seemed, however, to make no difference, and the lines in the stern had, as usual, the advantage. Possibly, after all, the cable and anchor may have more to do with it than one would naturally imagine, and be the cause which prevents the lines in the bow from having their full share of sport. 


\section{CHAPTER V.}

On Sea-fishing-Fine Tackle required-Best form of Tackle for general use_" Tell-tale" or "Dodger"-Baits-on South Coast-in Scotland-Fly-fishing in Sea-lochs-Mode of proceeding-Gaff essential-Executioner.

TT seems to me that the subject of Sea-fishing has never been treated with the attention it deserves. About Fly-fishing, Bottom-fishing, and nearly every other branch of the "gentle art," books enough to stock a library have been written, and but little remains to be said with regard to them; but as to Sea-fishing the case is altogether different. Comparatively little interest is taken in it as a pursuit, and those who would gain any information on the subject from books, will find but few which treat of it at all, and those in but a very meagre and cursory manner. And yet it is one for which these shores offer abundant opportunities; is in itself pleasant, interesting, and often very exciting, and one moreover in which success depends in great measure on the care and skill of the fisherman. 
People really seem generally to regard sea-fish as a low order of brutes, almost destitute of common instinct, and upon which any care or attention would be quite thrown away. A fisherman, who piques himself on the fineness of his rivertackle, and would sedulously clip off the sixteenth of an inch of gut which might project beyond a knot, or discard a whole length, if it happened to be at all flat or opaque, will yet be content to have next his hooks, when Sea-fishing, snooding as thick as an ordinary salmon-line, and often untwisted so as rather to resemble mop-yarn than what it pretends to be,-this roughly tied on coarse rusty hooks, and the rest of his apparatus clumsy to match. Now such a person need scarcely be reminded that all animals, sea-fish included, have an instinctive sense of danger, and that it would be difficult to convey to any one the knowledge that a trap is laid for him, more effectually than by exhibiting next the hook such very obvious machinery for his destruction. Why, it's a positive insult to the intelligence of the fish! "If a thing is worth doing at all, it is worth doing well," says the old proverb; and yet many a man at the seaside, when inclined to "have a turn at the Whiting," without taking the slightest trouble about 
the matter himself, simply tells any boatman, whom chance throws in his way, to have "hooks and lines and all that sort of thing" ready, an order which the man executes by looking out some rusty old tackle kept for summer-visitors,"they don't know no better,"-which he tells him are "all right." He, taking for granted that the boatman's tackle must be "the correct thing," goes out, perhaps never looks at the hooks, which are baited for him by the boatman, and comes back with two or three deluded flatfish and possibly a conger of a couple of pounds, all that he has to shew for several hours' work, and ten or fifteen shillings that the boat has cost him. Of course he attributes his want of success to wind, or tide, or absence of fish, never dreaming that his own carelessness has had anything to do with it.

As a practical proof of the advantage which fine tackle has over coarse at this work, the following striking instance will suffice:-I was out with a brother of mine, and a boatman who had been all his life used to the place and fishing, being indeed a fisherman by trade. He used his own coarse tackle, whilst my brother and I fished with our own-good hooks whipped on gut, 
and with lines, "chopsticks," \&c. fine in proportion. The result was that we caught some four or five dozen good pout, \&c. between us, while the boatman did not succeed in catching one single fish of any sort or kind. And it must not be supposed that his time was taken up with baiting our hooks; -we preferred doing that for ourselves.

There is perhaps no better form of tackle for general use in Sea-fishing than that commonly adopted of two "chopsticks" fastened at right angles, or nearly so, to each other, and having the plummet affixed to them at the point of junction. They should be about eight or nine inches long, the best material for them being perhaps whalebone, or really good tough wood, such as hickory. Stout brass wire however answers the purpose very fairly. This may be run through the upper part of the plummet, and the two ends, after giving each a half-turn round it, bent at right angles to each other. The object of having the chopsticks set at an angle instead of in a straight line is to make them hang steadily when the tide is running. They would otherwise be apt to turn round. When trying for heavy fish-Hake for instancewith a large bait, it is better to dispense with chopsticks altogether and use a single hook. At 
CH. v.] "TELL-TALE"-BAITS USED IN ENGLAND. 73

the end of each of the chopsticks should be a loop, between which and the hook should be about a foot of good gut. In principle of course the longer this gut is, the better; but in practice it will be found that if it is much longer than this, it is apt to get in the way-the hooks becoming entangled with each other, and the chopsticks. Any one who does not mind the additional expense, will find his comfort much promoted by the use of plaited lines, instead of the twisted ones, which are usually sold for the purpose, they being (at first particularly) abominably addicted to kinking, a habit of which it requires a good deal of time and trouble to cure them.

On some parts of the South Coast, particularly when fishing for Whiting-Pollack (Whiting-Cole, as they are there generally called), they employ, besides their hand-lines, one which they call a "Telltale" or "Dodger." This consists of a long hairline with gut next the hook, lightly leaded, and floated off astern of the boat by a large float or bung. On this they catch the best fish, and not unfrequently a Mackerel.

The principal baits used for sea-fishing along the coast of England are the lug-worm (generally called "lug"), shrimps, hermit-crabs (in the South 
called "gânsers" "), cockles, mussels, and pieces of fish, principally whiting and herring. These baits I have arranged according to the estimation in which I think they are generally held, regard being also had to the comparative difficulty of procuring them, which of course differs on different parts of the coast. Fish, as bait, stand somewhat apart from the others, as they are generally only used when others fail, though they occasionally answer extremely well, herrings especially.

In Scotland the baits used, so far as my observation extends, are more limited, as they seem to discard the use of lug, at least along the West coast, and to rely almost exclusively on mussels and cockles, the former being decidedly preferred. Pieces of herring, whiting, and the power-cod, are however much depended on, especially herring, than which it is indeed perhaps impossible to find a better bait. The worst of mussels is, that they are so difficult to bait with and so easily pulled off the hooks. This is, to some extent, obviated by par-boiling them, but unfortunately the fish decidedly prefer them au naturel. In baiting with mussels, the hook should always be first run through a small dark heart-shaped substance, po- 
pularly called the "tongue," as the toughest part. It will be found near that part of the fish with which it adheres to the rocks.

Where Cuddies (the young of the Saithe or Coal-fish) abound, it is almost hopeless to attempt fishing with mussels, for the moment the bait is down, it is nibbled off by them, while they themselves, from their small size (generally from four to six inches in length), manage to escape the hook.

The best way of having your revenge on them is with a small white fly made of a piece of goose's or gull's feather, which may be tied in the simplest manner, merely taking care to allow a piece of about three quarters of an inch in length to project beyond the hook. With flies thus made and set up in the following way almost any number may be taken:-You should use a stout rod and line, (which must be on a reel,) with a strong gut collar (casting-line) a little longer than the rod. To this collar you may attach, by pieces of gut three or four inches long, as many flies as there is conveniently room for. Eight or ten is a common number, but this may be doubled. Between the line and the collar it will be found very useful to have a swivel, and also above the tail-fly a weight, which may be a length of about a dozen shot, like 
those recommended for spinning. When thus ready for a start you should, with the point of your rod slanted down into the water (more or less according to its depth), and about fifteen or twenty yards of line out, be rowed over the most likely parts of it. You will probably, though tempted to do so at first, find it a loss of time to pull up as soon as you feel you have a fish on, but prefer waiting until the strain on the rod tells you that you have enough to make it worth while. Then, raising the point of it, up they will come in a string, perhaps from half a dozen to nearly three times that number. I believe I may say I have seen each of sixteen hooks on a line garnished with a fish at the same time, and I have myself brought up two on one hook. While at anchor I have, merely with a single joint of a rod, or a walking-stick, with two or three flies attached to it, caught scores of these little fellows, by simply moving it backwards and forwards under water. With a hoop-net, like a minnow-net on a large scale, great number's can be caught off the stern of a vessel at anchor, if they have been previously attracted to the spot by baiting it freely.

Were the sport, whilst fishing with the fly in the way last described, confined to Cuddies, it 
might be considered somewhat tame, but this is by no means the case, as, in addition to these, you catch very many larger fish, principally Lythe (Whiting-Pollack), which sometimes run up to twelve pounds weight or more, Stenlocks (the second growth of the Coal-fish ${ }^{1}$ ), and Codlings, with now and then, though rarely, a Mackerel. A day's fishing of this kinid therefore often yields, not only a numerous score, but a very respectable one in point of weight and variety.

Saithe (the full-grown Coal-fish ${ }^{1}$ ), which run up to a very large size-I have heard as much as twenty-five or thirty pounds-are occasionally caught in this way. Last year (1858), I was trailing, whilst running up a Scotch loch under sail with the wind, when one of my flies was taken by a large fish, which naturally ran off in an opposite direction to the boat. The sail being boomed out, before we could bring her round, he had run out the whole of my line, and, apparently without an effort, carried away casting-line and flies. This was probably a Saithe, and his weight could not have been much, if at all, under fifteen pounds, while it might have been double that.

The weight, the use of which I have recom-

1 See note, page 82. 
mended next the tail-fly, will be found advantageous, as it not only displays the flies to greater advantage, but keeps them nearer the bottom, where the heavier fish lie, while it enables you to keep the point of your rod much nearer the surface of the water, if not altogether clear of it. Care is however required when it is used, as the Lythe, when hooked, immediately run into the sea-weed, if they can, and thus often not only get off themselves, but cause serious damage to your tackle, which, for this reason, should be of extra strength. The swivel next the line will prevent the casting-line from becoming twisted, which will otherwise be invariably found to occur when fish are not taken in immediately, but pulled along for any time after the boat. To make the tackle perfect, there should be a small swivel between each fly and the casting-line.

It should be a standing rule never to go out Sea-fishing without a Gaff. If you also take with you a full-sized landing-net, so much the better. You can never tell what you may come across, and the Gaff may save you many a big fish, while the landing-net will be found a great assistance in enabling you to secure good ones,-such, for instance, as you would probably meet with many 
of in a day's Haddock-fishing, and which, though not sufficiently large to call for the use of the Gaff, you would still be sorry to lose. If your fish run large, and particularly if you are likely to have Hake or Congers to deal with, it is also quite as well to be provided with a short heavy stick as an "executioner", for-irrespective of humanity - four or five such fish, if left to their own devices on board, are apt-especially if your boat be a small one-to make themselves anything but pleasant compagnons de voyage.

1 See page 31. 


\section{CHAPTER VI.}

Lochs on West Coast of Scotland-Animal life-Shell-fishFish-Plague of Dog-fish-Lobsters-Salmon and Seatrout-A singular trio-Salmon detained in Salt-water become diseased-Artificial "Spate" for Salmon-Salmon passively following the line when hooked.

THE way in which some of the Sea-lochs on the West coast of Scotland teem with animal life is truly marvellous. The shores are in many places literally covered with Shell-fish, which are exposed at low-water, while the lochs seem to abound with fish almost to an equal extent. The Shell-fish mostly consist of mussels, cockles, winkles and oysters, and, when I say that the shores are in parts covered with them, I am not in the least exaggerating the actual fact. I well remember, when I first made acquaintance with that part of the country, my surprise at being shewn in Loch Creran a dark-blue bank, forming at low water a peninsula perhaps a hundred yards long by some fifty wide, and being told that the colour of this proceeded from mussels. I half thought my 
informant was joking, but, on landing, found that he was not only in earnest but perfectly correct, the whole of it being one mass of mussels (mostly small), lying edgeways, and so densely packed that it would have been apparently a matter of difficulty to insert a pin's point between any two of them. It seemed difficult to comprehend how, under the circumstances, they could manage to open their shells sufficiently for the necessary functions of life. Oysters too were numerous, but in consequence of the increasing demand for them they are more sought after than they used to be, and it would not be perhaps now quite so easy to gather a sackful as it was a few years ago. Vessels also come round occasionally for winkles, and take away cargoes of them to Glasgow, but there are apparently enough to withstand such inroads for many a long year to come. On the mussels it would seem that nothing can make the least impression, so vast are their number's.

Of all the fish which inhabit the Scotch lochs, Cuddies are by far the most numerous. They seem perfectly ubiquitous there, and occasionally swarm to an astonishing degree; so much so sometimes as positively to discolour the water in places where abundance of food has 
induced them to congregate. Next to these, Cod and Codlings, Flounders, and Lythe are generally the most plentiful. They are, however, varied by many others, among which I may particularly notice, as very familiar, those sea-pike, the Hake, brutes for whom it is the fashion to fish with a hook apparently large enough for a Shark, affixed to a chain nearly as large as a jack-chain, but which-however little one might suspect it from their formidable rows of teeth, and (occasionally) voracious appetites-seem to nibble as gently and delicately as a roach, and, when they are not inclined to bite, are often felt rubbing against your plummet, and actually raising it up, as if they were scratching their backs against it,-as I dare say they are; Gurnet, who when they are hoisted on board, and at intervals, as long as they have power to express their feelings, grunt out their disapprobation of your proceedings; the beautiful little golden-opal-tinted Power-Cod, there called "King-fish" (I am sorry to use so many epithets, but he deserves them all); Sillocks" (Stenlocks or Stedlocks) and Saithe (Coal-fish of more advanced

1 There is some little confusion with regard to the names of this fish, which differ in different parts of the coast. Although Sillock, Stenlock, and Stedlock are, I believe, always 
ages); the Sea-bream (Scoticè, on West coast, "Silver Haddie,") strong in the water, brilliant of eye, and hard to handle; the Skate, whose face when turned on his back presents a most ludicrous resemblance to that of a crying child; and the hideous Sea Devil, all mouth and fins, looking like a cross between a toad and a night-jar. Specimens of rarer fishes are too occasionally met with. Last year, for instance, I took out of a Lobster-trap a Three-bearded Rockling, as mentioned below (page 86), and this year (1859)-on a long line-one of that remarkable and fantastic looking species, the Gemmous Dragonet, seven inches in length.

As you leave the shelter of the lochs, and stand out farther into the open sea, the varieties of fish which you will bring up become more largely increased, and commonly embrace Haddock, Tusk, Ling, Conger-eels, and Nurse ("Small Spotted Dogfish," Yarrell), (though the three latter also often

used to denote one growth of the Coal-fish, and Saithe another, yet in some plaees the half-grown fish are ealled Saithe and the full-grown ones Sillock, \&c., whilst in others, and more generally, the reverse is the case. As compared with Salmon the three growths of Cuddy, Sillock or Stenloek, and Saithe, would very nearly, in weight as in other points, correspond to Salmon-fry, Grilse, and Salmon. 
find their way far up into the larger lochs,) with several other species, "quos nunc describere longum est." Nurse are not generally considered very good for the table, but I met last year a gentleman who told me "in confidence," that he considered them, as a foundation for soup, better than any other fish, adding that from their being held in slight estimation by others he generally managed to get on easy terms those which were caught in his neighbourhood. I hope he won't be angry with me for "blowing on" his secret.

Last spring (1858) the North West coast of Scotland was visited by a plague of Dog-fish, which swarmed in such inconceivable numbers that the ordinary deep sea-fishing was rendered almost entirely nugatory, much to the injury of the poor fishermen, who in great measure rely upon the produce of this occupation for their living. It was perfectly useless to set long lines, for only the Skeletons of the Cod, \&c. were brought up, the voracious Dog-fish having torn them to pieces and picked their bones on the hooks. It was indeed as much as they could do, even when fishing with hand-lines, to bring any to the surface before pieces had been bitten out of them. I have been told of an instance where a fisherman hauled in 
three of these beasts with their teeth fast into a Cod which he had hooked,-and of another, where a man, before taking in a Cod which he had brought to the surface, pulled out with his hand no less than nine in succession, as they endeavoured to seize it. An attempt was made to utilise the Dog-fish, by extracting oil from them. They were however, from their numbers, half starved, and so miserably poor that it was a complete failure.

It can lardly be wondered that Dog-fish are universally objects of detestation to fishermen, by whom no mercy is shewn them, and who sometimes indeed wreak their vengeance on them in very cruel ways, such for instance as by sticking corks on their dorsal spines, when, being unable to descend, the poor wretches must miserably end their days upon the surface, unless released from their sufferings by a passing Gull. I have seen, when a boy, eight or ten of them tied along a stick, and thus sent adrift together.

Besides the fish which I have mentioned as inhabiting the Scotch sea-lochs, in some of them, and particularly those of some of the Western Islands, Lobsters are numerous, and run to a great size. For these some friends and I, whilst in shooting quarters by one of these lochs, utilised 
S6 DRUM-NET-LOBSTERS-WHISTLE-FISH. [PART I.

with great success a common Drum-net, which I purchased (originally with a view to eels) at Good's, in King William Street, City,-where I also got the best snooding, in point of strength and fineness, that I have ever seen-finding it well adapted for the purpose, and admitted to be far superior to those which are generally used there by the resident population. These latter are, as well as the former, made of net stretched over a wooden frame, but form a shape like a trunk with an arched top, having one or two apertures in the sides to admit the fish. The Drum-net is formed of a net stretched upon three hoops, kept apart by sticks fastened to them, the ends of the net being drawn in by strings leading through to the opposite end, on the principle of the eel-pot:"Facilis descensus Averni, sed revocare gradum!" In this manner we caught a considerable number, more indeed than we well knew what to do with, including one weighing upwards of seven pounds, and another, minus one of its large claws, of six pounds and a quarter. Not unfrequently an Eel or other stray fish would find its way into the hoop-net, one being an unusually large specimen of the Three-bearded Rockling or Whistle-fish, two pounds weight, and eighteen and a half inches long. 
The heads of those Sea-lochs which form the embouchures of favourite Salmon-rivers, often become the temporary resting-places of Salmon and Sea Trout, which are not unfrequently weatherbound there for weeks together, being prevented by want of water from ascending the river for which they were making. The fish meanwhile continuing to flock in, such a loch, after a long spell of dry weather, sometimes swarms with them in a manner scarcely credible. I know of one, the precise locality of which I trust I shall be forgiven for not pointing out,-

"There is a stream, I name not its name, lest itinerant Tourist

"Hunt it and make it a lion, and get it at last into guide-books.'

(Clough's "Bothie.")

where, under such circumstances, I have seen the Salmon and Sea Trout congregated in fabulous quantities. Some idea of their numbers may be gathered from the fact that in the month of July, when they throw themselves out of the water more than they do later in the season, I several times tried whether I could count ten between the appearance of any two fish, and on every occasion was interrupted before I could get to the "ten" 
by the splash of a Salmon. At these times they appear to be almost regardless of the presence of a boat, and will throw themselves out of the water right under the oars. I found it a matter of positive difficulty to restrain myself, when fishing for Sea Trout, from hitting at them with my rod as they "walloped" up under it within four or five feet of me. A good Sea Trout about the same time measured his distance so badly as actually to jump into a boat close to mine. The Sea Trout may, when there is a slight breeze, be caught in great numbers with the fly in this brackish water. Salmon, however, will rarely take it there, but, under favourable circumstances, such a thing is by no means unknown. I believe I am correct in saying that in this loch three Salmon (or Grilse) were killed in one day by the same rod in the month of June.

A friend of mine, whilst fishing for Sea Trout in the same loch, brought up at once on his three flies a Sea Trout, a Codling, and a Cuddy, certainly not a common occurrence.

I have been informed by people living on the spot that Salmon, if detained for a lengthened period in the Salt-water waiting for a "spate," sometimes become subject to an affection of the 
head, first manifesting itself by a small white spot on it, and subsequently producing blindness, numbers having been known to die from this cause. The flesh is said not to be affected by this disease, but to remain perfectly good for the table.

A gentleman with whom I am acquainted, and who rents a river rumning into the head of a loch, in - shire, thought it would be possible, by an artificial spate, to induce any Salmon which might be waiting for a natural one to ascend his river. Accordingly he had a large dam constructed across it, so as to head back a considerable quantity of water. Some weeks of dry weather ensued, during which his fishing was at a stand-still, and the neighbouring farmers took advantage of the pool thus formed for the purpose of washing their sheep, for which operation it afforded a convenient place. At length his patience became exhausted, and a number of Salmon having become congregated at the head of the loch, he caused the sluice of his dam to be raised, and down rushed his spate. Instead, however, of the Salmon taking advantage of it to ascend his river, they, disgusted at the foulness and staleness of the water, turned tail and retreated before it; the proof being that on that night a large number were caught in the 
accursed bag-nets, which were waiting to receive them a couple of miles below, and which had, for some time previously, yielded comparatively little. It is said that the Salmon have never forgotten or forgiven this interference with the natural order of things, and that those which now visit his river are neither so numerous nor so large as those which used to do so before this dodge was attempted ${ }^{1}$.

After Salmon have been hooked, if they have not been very sharply struck, they will not unfrequently allow themselves to be drawn along for a considerable distance-even till close to the shore -quietly following the pull of the line, without the slightest struggle or attempt at resistance, and apparently quite unconscious of their danger.

I am somewhat at a loss to know how this is to be accounted for. It can scarcely be that they do not feel the hook, for, although a Salmon will sometimes rise at a fly several times in succession, and perhaps be caught after all by a judicious

1 Having given this story on the authority of some of this gentleman's neighbours, I am bound to add, that, from what I have subsequently heard, I fancy they made the most of it in the telling. As, however, I believe there is still a good deal of truth about it, I let it stand with this reservation. 
change from dark to light, or the reverse, yet, if he have once been touched, he will but rarely come again the same day. I suspect they must be fairly taken by surprise, and so puzzled by the power thus mysteriously brought to bear on them, as to be at first unable to make out what is the matter, and what they had better do under the circumstances.

It must be admitted, however, that when they have once made up their minds as to a course of action, they do not lose much time in carrying it out; and then is the time when the fisherman must "look out for squalls." For this reason, however passive and tractable a fish may appear, he should remain well on his guard, and ready on the instant to adapt himself to the vagaries of the fish, who, if a good one, will soon show him that there is plenty of "life in the old dog yet."

Though fully aware of this peculiarity in Salmon, yet I very nearly lost one last season, (1859), owing to it, under rather peculiar circumstances; it being certainly more attributable to luck than my own cunning that I ultimately succeeded in landing him.

I was fishing from a boat a loch in Ross-shire, on a very stormy day, so rough indeed that it was 
quite as much as two men could do to keep her "head to wind," and had cast between two rocks lying at some little distance from the shore, and forming a favourite harbour for Salmon, when amidst the breakers (as they might be well called) I detected a slight rise. The loch was full of small brown Trout, which always seemed most numerous and annoying at a Salmon-cast, and I rather thought it was one of these. Not being quite sure however, I struck, when, feeling just about as much resistance as one of them would have offered, and the Gillie next me, who was on the look-out, and whose eyes were much sharper than mine, at the same time saying, "Oh! its just a Brownie, Sir," I naturally concluded such must be the case, and, throwing my rod over my shoulder, laid hold of the line and drew it in by hand, as the quickest way of getting rid of the little brute. The line came in without the slightest strain upon it greater than a Brownie would have caused, and it was not until I had got the fish close to the boat and within three or four feet of my hand, that I had the slightest suspicion I had on anything heavier. Suddenly, however, I then felt that it was something of more than Brownieweight, and had only just time, after assuring my- 
self that whatever it might be, it was worth catching, to get hold of the rod with my right hand, than out spun the line, cutting into the fingers of my left hand, through which I managed to ease it, until I could bring the rod into play. Then "whirr" went the reel, and the next instant, at some thirty or forty yards from the boat a Salmon of over twelve pounds flung himself-and again-and again-out of the water. I need not continue the story. The rest of the business, after he had "had his fling," and I had got him under command, was simple enough; the result being that in a quarter of an hour or so we were "wetting" 1 " him under" a sheltering rock, while the little dog, to whom I allude at greater length elsewhere, was prosecuting his usual search after field-mice.

1 Let not the Angler at such a time be chary of the contents of his flask-or of his tobacco-pouch-if his Gillies have done their work well. His success in great measure depends on their cheerful and active cooperation, and there is perhaps no way more calculated to insure this than a slight largess thus bestowed.

But-apart from any application of the principle that gratitude is "a lively sense of favours to come"-there is something cheery in the "wee drappie all round," and the "better luck still, Sir," which preludes the tossing off of each. Master and men will work together all the better for it, and the result will be all the worse for the Salmon. 


\section{CHAFTER VII.}

Fishing from Steamers-Whiting near the surface-A day in the Linnhe Loch-off the Brambles-Lady-birds at seaBoat-dress for bad weather-Advantages of Cape-Other Hints as to Dress-Knickerbockers-Belt-Cap-How to pair Gloves-Fish-taxidermy.

THE passage by the Scotch steamers along the 1 West coast-I am referring particularly to those running between Glasgow and Stornowaythough in many ways pleasant enough, is often rendered tedious by their long stoppages at the different halting-places, while taking in or unloading wool, cattle, herrings, or other goods of which their very miscellaneous cargoes consist. Several hours at a time are not unfrequently thus consumed with much more profit to the Company than satisfaction to the passengers. As, however, many of these stoppages occur in Lochs which abound with fish, these hours may, for want of better occupation, be wiled away pleasantly enough by fishing over the side. The steward generally 
has a line or two on board, and will be delighted in assisting you to catch a dish of fish for the table by lending them. These are, however, for the most part such make-shift things, that any one who has a mind to utilise his time in this way will do well to invest a shilling or two in a good one before starting. Fish-bait is generally procurable on board. I have myself had excellent sport in this way at several places along the Coast, particularly off Gairloch and in Little Loch Broom. At the former place I remember creating great excitement amongst the boats alongside, by getting hold of a big Stenlock. He was so heavy and the tackle so rotten-I was fishing with the steward's - that I could not venture to haul him on board. At length one of the boatmen came to my assistance, killed him, and fastened the line round his gills, when he came up all right. He weighed nearly ten pounds.

Although Whiting are generally taken near the bottom, yet it is a mistake to suppose that they never leave it; for they not only have the power of coming to the surface, but in fact not unfrequently do so, or to within a short distance of it, when in pursuit of small fry. I know of two instances in which they have been caught by a kill- 
devil trailed from the stern of a rowing boat off Guernsey-where, by the way, first-rate sea-fishing is to be had-and I myself had satisfactory proof of the fact whilst fishing in the Linnhe Loch off Ardsheal. On that occasion we were pulling up Whiting so fast, that, my line becoming kinked, $\mathrm{I}$, in order to save time, put my bait overboard to be all ready when the boatman should have cleared the knot. My line could not thus have reached above a third of the way to the bottom, when, to my surprise, I felt a tug. I struck and pulled away, bringing up two fine Whiting. Profiting by this experience I did not afterwards waste time by allowing my bait to sink much lower, and found consequently that our heap of fish grew much more rapidly under my contributions than those of my friends who adhered to the orthodox mode of fishing at the bottom. Our sport that day was, while it lasted, as good as I ever had. There were three of us, besides the boatmen, whose time was pretty well taken up with attending to lines. We started very late and with appearances much against us, the only procurable bait being seven herrings in such an adranced state of decomposition that we were too glad to avoid getting them between the wind and 
our nobility. In fact they were so bad that we had serious doubts whether it was worth while to attempt fishing with them at all. However, our spirit of enterprise prevailed over our doubts, and we concluded to try our luck. The first omen of our success was a Herring, which was caught with a piece of one of his putrid predecessors, almost as soon as we commenced fishing. I need hardly say that the new-comer's appearance was hailed with a shout of welcome, and that, in a trice, bright strips from his sides were doing duty upon all the available hooks.

"At length they caught two boobies and a noddy, And then they left off eating the dead body."

After this god-send we began catching fish in earnest, and were, in fact, as hotly engaged in hauling in, baiting and letting down again as could well be, until, remembering that the ladies would be waiting dinner for us, we unwillingly wound up our lines, having then been fishing only about a couple of hours, and pulled homewards.

It is very unusual for Herrings to be taken with bait; but that which first gave us our real start, was not the only one which we caught that day, no less than eight others having been, one after another, brought on board and converted into bait. 
Besides Herrings however we were plentifully supplied with other bait, in the shape of small Herring-fry about the size of White Bait, with which many (most I may say) of the Whiting were perfectly gorged. The number of fish we brought home was (exclusive of those used as bait) three hundred and seven, weighing a hundred and sixty-one pounds, chiefly Whiting, but comprising, amongst a few other varieties, a Cod of sixteen, and a Skate of about seven or eight pounds. The Cod was caught on a Whiting which had taken the bait, and came up alive in his mouth. The feeling of relief, when we found we might dispense with our first unsavoury lot of Herrings, to which we had resigned ourselves as our only chance of success, and got them well overboard, was, it may be conceived, not inconsiderable.

The best day's sea-fishing that I ever had in the South of England was towards the end of August, near the West buoy of the Brambles, not far from the mouth of the Southampton river, when, in one tide, (or, to speak more correctly, part of two tides), two other lines and my own, assisted occasionally by those of a couple of boatmen, caught twentyfive dozen and eight Whiting (singularly enough, the same number within one as that mentioned 
on the last occasion), besides some other fish. On the previous day we had caught exactly haif the number, twelve dozen and ten. The fish bit most freely when the tide ran so hotly that we could scarcely "hold bottom," and they came whirling up against the current two at a time as if they were spinning-baits that we were using for larger fish.

On that day I noticed vast numbers of Ladybirds drifting along by us with the tide to the eastward as we lay at anchor. Where they had come from, or where they were going to when they fell into the water, it is not very easy to conjecture. There was no wind where we were, and the actual surface of the sea was of an oily stillness: a long swell was, however, plainly discernible, proving that at no great distance there had been a good deal of wind, which might have driven them off shore, or, what is more probable, caught them whilst in the act of changing their quarters en masse and beaten them down into the sea.

The best dress that I know for boat-work in wet weather consists of a pair of macintosh overhalls made to tie round the waist, a light cape of the same material, about thirty inches long, and an oil-skin wide-awake. The overalls should be 
sufficiently large to enable you to put the skirts of your shooting-coat bodily into them, by which means, while you have access to your upper pockets, the lower ones will be kept dry and you will be perfectly impermeable to wet, there being nothing about you to catch the rain.

The overalls are most useful at all times in sea-fishing, as they afford complete protection fore and aft, and enable you to haul in line and fish without getting your knees wet, as well as to sit down in comfort wherever you please, no matter what the state of the boat may be.

Of course it does not much matter for boatwork what the length of the cape is. I mention thirty inches, because I have found such a one most useful on shore, as well as on the water, for shooting of all kinds, or other fishing. If you have no one at hand to carry it when not wanted, its weight is but little felt in your inner coat-pocket, or, what is better, it can be rolled up and fastened by a couple of little straps or strings to the strap of your shot-bag or fishing-basket, in which position you are really scarcely sensible of its presence. It will save you many a wet jacket, and the annoyance of getting all the things in your pockets drenched and perhaps spoiled. I scarcely know 
anything more aggravating than, when turning homewards after your work is done, and you are longing for a quiet pipe, to find that your matches are all saturated and no light is procurable. While actually shooting, the cape will be found surprisingly little in the way, it being easy to dispose it, so that, while your locks are protected, you can instantly throw it aside sufficiently to shoot with ease. When going up to a point, you can, if you please, throw it quite back off the right shoulder. The only thing against it, that I know, is that in a high wind it is apt to get blown up over your head, but this is easily obviated by having a button sewn on inside it at the bottom, and a corresponding button-hole in the middle back-seam of your shooting-coat.

While on the subject of dress, I will just say a word as to one or two other points. By far the best leg-coverings for walking in an open country are, I think, knickerbockers. These are generally made to buckle at the knee, so that they cannot be worn otherwise. I rather prefer however, for grouse-shooting, to have them simply cut quite loose, so as to hang about six or eight inches below the knee, with strings run through the bottoms to tie on the inside, and a slit, also in the 
inside, extending a little above the knee. When on comparatively level ground, if the material of which they are made is moderately light, I find it rather cooler and pleasanter to leave them hanging down, with the strings just tied loosely. On coming to any really hard work in the way of steep ground, when it becomes necessary to bend the knee much, they can be in a moment drawn up over the calf, and tied tightly so as to prevent them from slipping. The slits should on no account be made outside, or the midges and "clegs" (horse-flies) will make your life a burthen to you.

An elastic belt round the waist is infinitely preferable to braces. It should be tolerably broad, and fastened by a buckle, not a clasp, so that you can let out a reef when you like. Very good ones are made by Weatherhead, of 27 Panton Street, Haymarket.

The best kind of cap that I know for sea-fishing or deer-stalking-having its origin, I believe, at Scatwell, in Ross-shire-is very simply made as follows. The crown consists of four pieces coming to a point at the top, and fitting closely to the head. Before and behind there are peaks to protect eyes and neck, and on either side, springing 
CH. VII.] TO PAIR GLOVES-FISH-TAXIDERMY. 103

from the extremities of the peaks, a lappet, one furnished with a loop, the other with a button, and made long enough just to fasten over the head, or under the chin, at pleasure, forming in the latter position a covering for the ears, which those who have, when after deer, lain for hours on the hillside, waiting for the mist to clear off, will readily appreciate. It should be made, I need hardly say, of some unobtrusive-coloured woollen stuff.

It is a remarkable fact, that, although you may have put by your old gloves in pairs against the next shooting-season, you will not unfrequently find your stock, when you come to use them, to consist almost entirely of left-hand gloves. Whether this may arise from the fact that housemaids generally clean the grates with the right hand, and like to keep that clean also, we need not inquire; I would only suggest to any one who may find himself with two odd gloves in his pocket, not to "cuss and swear," but just turn one of them inside out, when he will have a pair that will do to shoot in, at any rate.

Judging from the miserable failures which constantly offend the eye, it would appear that the art of stuffing fish is one in which it is very difficult to attain to a result at all approaching 
perfection. So-called preserved specimens are almost invariably stuck straight up in the middle of their cases-fins and tail stretched to the utmost possible limits-eyes, the largest that can be forced into the sockets, and guiltless of any attempt at speculation-body often stuffed out like a "rolly-polly" pudding, and the colour generally toned down to a rich deep mahogany: all this too very frequently without the slightest accessories of weed or stones to relieve the barren dreariness of the case.

Conceive a portrait-painter representing his subject as standing, without fore or back-ground, "straight to the front," staring before him on vacancy with distended eyelids, his legs as wide apart as possible, his arms extended at right angles to his body, and the whole coloured $a ̀$ la Mulatto. Such a portrait would be deservedly treated as a caricature: yet it would probably convey about as faithful an idea of the man, as the other of the fish. It may not be easy to give much expression to the eye, but surely our Taxidermists, by devoting a little more attention to this branch of their art, might succeed in generally investing their fish with more life, truth, and character. 
It is now quite a matter for condolence to see a fish on whose perfect condition and lovely colour you gazed with fond admiration, as he lay on the bank your prize after a well-fought battle, transformed into the wretched Mummy which he too often appears when returned to you from the hands of the Stuffer to whom you had, not without a feeling of pardonable pride, entrusted him.

The two points which seem to present the greatest difficulties in the preservation of fish are, the tendency of the skin to shrink and get out of shape, and to lose its colour and become dark. The specimen in which, to my mind, these obstacles have been most successfully surmounted, is to be seen in the shop-window of a worthy fishing-tackle maker, Roblow, of 30 Upper Marylebone Street, Portland Place, being that of a Trout (fourteen pounds weight, he tells me), caught at Teddington Weir in 1846. It must have been a "perfect picture" of a Thames Trout, and well deserves a visit. 


\section{CHAPTER VIII.}

Spearing Flat-fish-Have Flat-fish the power of changing colour at will?-Spearing ditto off Ryde-Nest of Stickleback-Deceptive appearance of Fish in water-Instances -of Jack-of Trout.

THERE is worse sport than spearing Flat-fish, 1 "fluking," as it is called in the South of England, which in sandy estuaries (the favourite resorts of these fish) may often be practised with considerable success. A four or five-pronged spear is the best for the purpose. The prongs should be about three inches apart, and barbed on one side, and the cross-piece, to which they are affixed, attached to a light tough pole just long enough to admit of easy use in the water you are fishing. The simplest and best mode of working this is, when practicable, to allow your boat to drift down with the tide, "broadside on," while you spear away at random, or, when the water is sufficiently clear and shallow to admit of your doing so, reserve your fire until you see a. 
fish to take a shot at. Great numbers may be caught in this way near the mouths of some of the Devonshire rivers, amongst which I may mention the Erme and Teign, as being extremely well adapted for the purpose, and affording abundance of Flat-fish.

When a boy, at a private tutor's not far from the former, I used with a spear which I kept hidden in some gorse near our bathing-place and took into the water with me-perhaps up to my breast or chin in it-to pick up a great many. I remember on one occasion striking and securing three at once. My plan for getting a good one off the spear, as its barbs were not in first-rate working order, was to insinuate my foot under the fish, and getting a toe on each side of the prong on which he was, to raise up foot and all until I could reach it with my hand, and take him off, when I pitched him on shore to wait until I came out.

Hugh Miller, in that very entertaining book of his, My Schools and Schoolmasters, asserts that Flat-fish have the power of changing their colour at will, making it accord with that of the bottom on which they may happen to be lying. He, alas! poor fellow, is no longer among us to throw 
additional light on the subject from his own experience, and I hesitate to express an opinion at variance with that of so accurate an observer of nature. I cannot however but fancy that in this instance he may have been deceived by appearances. Undoubtedly the Flat-fish does apparently assume the colour of the bottom on which he rests, but, so far as my observation", extends, this is only because, the moment that he halts, by a motion of his fins and tail so rapid as to be almost imperceptible, he throws up over his back some of the surrounding sand, working himself down as he does it to a lower level. He thus becomes in a wonderfully short space of time almost invisible to an unpractised eye, and might easily be supposed actually to have changed colour.

I do not, of course, go the length of saying that Flat-fish do not in time become assimilated in colour to that of the bottom on which they generally lie. On the contrary, knowing that other fish-Trout for instance-do so, a fact which cannot but have forced itself on the notice of every angler, I should have been much surprised had I found that this property was not participated in by Flat-fish. My observations merely extend to their supposed power of changing colour at will. 
I used, when a boy, to have very good opportunities of observing this expedient of theirs to escape detection; it being one of my favourite amusements, when the tide served-low-water spring-tide was the best time-to start very early in the morning, accompanied by the garden-boy, each of us provided with a two-pronged steel fork, elaborately sharpened, and a basket, to the sands near Ryde, where in the pools left by the sea we used to find and spear (or rather fork) a good many stragglers, with now and then an Eel, who had also forgotten himself, and been left behind by the tide. The Flat-fish we were obliged to approach with care, stalk them, as it were; but when an Eel was started, we had to "chevy" him to his harbour amongst the stones, where with care in due time we generally managed to fork him. Our best morning's work, if I remember right, consisted of seventy-five Flat-fish, and six Eels, besides a lot of Cockles, with which, as we outstayed breakfast-time, we did not disdain to amuse ourselves on the road homewards, they being not at all unpalatable to a hungry boy, and easily opened, an office which one shell kindly performs for another by the following very simple process :-Two of them are placed dos à dos with 
the hinges fitting into each other crosswise. You then give them a twist, when the weaker, as is the way of the world, gives way to the stronger, and his delicate, yellow, hooked form, "the soul of his beauty and love lies bare," exposed to your tender mercies. Though I dare say many of the Flat-fish were not very large, yet some of them were really of a very respectable size, being nearly as large as soup-plates: the Eels were not remarkable for their proportions. However the whole made up a basket of fish which I was uncommonly proud of, and, I think, contributed a little to propitiate the authorities, from whom, as it was, I got a very decided "wigging" for my audacious conduct in making my appearance some three hours after I ought to have been at my lessons.

I used, on these occasions, to notice with much interest the nests of the Stickleback, which were far from uncommon in the pools where we found our Flat-fish. They were almost invariably formed by oyster, or other flat shells, the large ends of which were slightly raised above the sand, and presented generally so uniformly similar an appearance, that I scarcely ever failed to detect one of them among a number of ordinary shells in the vicinity, my suspicions being very frequently con- 
CH. VIII.] APPEARANCE OF FISH IN WATER.

firmed by finding the parent fish at home, taking charge of her eggs, which were deposited under it.

It is difficult for any one to judge accurately of the weight of fish in water, but persons unaccustomed to see them there are liable to be greatly deceived with regard to them, as on shallows they are apt to appear larger than they really are; in deep water, on the other hand, generally smaller.

I was considerably taken in by a mistake of this kind last spring (1858) whilst fishing a part of the Stour, below Iford, where I knew there was a very large Jack, having seen another of about two pounds, which had been picked up dead there, marked with the scores of enormous teeth, shewing that he must have been gripped by a monster. Opposite to me was a high bank, from which a man, who happened to be standing there, could see all that was going on below him, whilst I, fiom my lower position, nearly on a level with the water, and the direction of the sun, which was in my face, could see comparatively nothing, not even where the beds of weeds lay, at any distance from the bank from which I was fishing. All of a sudden he called out, "There are two fish at the tail of they weeds there, and one of em's a tremendious beost." I asked him whereabouts they were, and 
threw gradually up in the direction he pointed out to me. After two or three throws I succeeded in hitting the place and moving the big one. "He's coming, Sir," said he. "No: he's left it again. My G- what a fish! there, he's at least three foot long," and several times he repeated the same thing, saying that he could see him distinctly, and that he was "at the very least three foot long." Of course I concluded that this was the big fish, and was proportionably anxious to get him. Several times I threw "just right for him" (the man said), and once or twice he lazily followed the bait, returning after each such feint to his former position. By this time my bait was getting very much the worse for wear, and the reserve was in the boat, a good way up the river. However, at last, seeing that he really seemed too indolent to follow the bait, I thought I would humour him, and see whether he would take it, if it waited for him. Accordingly the next time he came at it, I stopped it entirely. This attention was too delicate for him: he could not resist it,and, without a pull or an effort, just closed his mouth upon it. "He's got it, Sir," shouted my fugleman; "Well, you have got a fish now." I "jabbered it into him," and feeling that it was 
CH. VIII.] "PARTURIUNT MONTES, NASCETUR \&c." 113

"all right," shouted for the fisherman to come down with the gaff from the boat where he was in attendance on a friend. I soon found, with some disappointment, that I had not so much to contend against as I expected, and asked the man on the bank, who was still anxiously watching my proceedings, whether he was quite certain it was the big fish that I had got hold of. He answered that there was no doubt at all about it, and I still hoped against my better judgment, but was soon disgusted at finding that I was right, when the fish, on being gaffed, turned out to be only five pounds and a half, instead of some twenty-five, which he ought at least to have been, had his length been really that which it was represented to be. The man could scarcely believe his eyes when the fish came out of the water, nor understand how he could have been so egregiously mistaken ${ }^{1}$.

Something of the same kind (though indeed in this instance the fish was judged of the same weight out of the water as in it) occurred to me

${ }^{1}$ Since this was written, a Jack of thirty-eight pounds was caught with a live bait this spring (1859) in the exact part of the river referred to. This was, I have no doubt, the very fish that I was trying for, and the marks of whose teeth I had seen in the smaller Jack. 
some years ago near Carshalton. I had permission to fish from several of the proprietors there, and was told there was no doubt that, if I called upon a Captain D. (who had some fishing), and sent in my card, he would also give me leave. I consequently started, rod in hand, to do so, but found that he was not at home, though shortly expected. Whilst awaiting his return, my attention was attracted by a small piece of the river running down through the garden of a worthy tobacco-merchant. I had not then a notion who lived there, but thought that nothing would, at any rate, be lost by asking for leave to have a cast or two en attendant. Accordingly I went in, and knocked at the door. It was opened by the butler, who told me his master was out, but that he could take upon himself to say that he would have great pleasure in permitting me to fish, and that I might certainly do so. I did not wait for more, but, with many thanks, best compliments to his master, and all that sort of thing, commenced putting my tackle together. Some men were at work engaged in mowing the meadow next the house, and as soon as one of these fellows, an Irishman, saw me thus occupied, he came rumning across the field to me, saying that in the morning he had seen a splen- 
CH. VIII.] NOT QUITE SUCH AN IMPOSTOR.

did Trout lying under "thim bushes" which he "knowed" was not under five pounds. Well, I set to work, and almost the very first throw I had him, raising him in the exact spot which had been pointed out to me. The gardener came to my assistance with an extraordinary machine used for dredging up gravel, or something of the kind (for I had not a net with me), and between us we landed him. No sooner was he on the bank, than my friend the Irishman came running up again in a state of the greatest delight, dancing round him, and exclaiming, "Arragh now! didn't I tell your Honour he was over five pounds?" The steelyard however returned him as only three and a quarter, but he certainly was one of the most beautiful and perfectly fed fish I ever saw. I was so proud of him, that I really could not make up my mind to give him to the gentleman, who had, through his butler, so kindly given me the opportunity of catching him, as I doubtless ought to have done; and hope that he will, though somewhat late, accept my best thanks for his courtesy, and this expression of my regret that I was induced to treat him so scurvily. 


\section{CHAPTER IX.}

Ember-cooking Fish-Fishing in Glen Garry-Big Salmo ferox-A Fisher-dog.

THERE is a way of dressing fish, which may be resorted to by the side of the water with pleasure (and not without advantage should your stock of provisions run short) during the middle of the day, when fish do not generally feed so freely as at other times, and when your sport is often improved by giving them, as well as yourself, a rest. It is managed as follows :-first collect a lot of small dry wood and set it on fire;-when a sufficient quantity of ashes has been thus obtained, which will be soon done, take a sheet of paper (an old newspaper will do) and wet it thoroughly: shake the drops off it, and then, filling the mouth of your fish with salt, wrap him up in it just as he is, uncleaned, "simplex immunditiis," and digging a grave for him in your ash-heap, put him bodily into it, covering him well up afterwards 
with the hot ashes. When you think he ought to be done, allowing from ten minutes to a quarter of an hour according to his size, partially uncover him and tear off a small piece of his winding-sheet. If his skin comes off with it, he is sufficiently done, and out with him. Should however the paper come off minus the skin, cover him up again, and give him a little more law, until this test shows him to be perfectly done. On being turned out of his envelope, the whole of his skin should adhere to it. As for his inside, you may disregard it altogether, or opening him, turn it out, which you will find there is not the slightest difficulty in doing en masse. Pepper and salt him, if you have such condiments by you, and you will only be sorry that your own kitchen does not afford you the means of dressing your fish thus at home ${ }^{1}$.

This plan was shewn me a year or two ago by a gillie on the shores of Loch Garry, the waters from which flow down the Garry to Loch Oich, the central one of the chain forming the Caledonian Canal,

1 I observe that this mode of dressing fish has already been described by Mr Stoddart in his Angler's Companion. As, however, it is possible that these Notes and his excellent work may fall under the notice of different readers, and the "wrinkle" is one worthy of being widely disseminated, I venture to let it stand as I have written it. 
and thence diverging East and West find their way to the German and Atlantic Oceans. The river, deriving its supplies from the contributions of several streams rising in the neighbourhood of Glen Coich, runs, before reaching Loch Garry, with no inconsiderable volume through two other lochs, by name Polery and Kingie, broadening out here and there during the rest of its course into large deep pools, of which I may mention one particularly, called "The Black Pool." The river, down to its efflux from Loch Garry - as well as the lochs through which it runs-abounds with Brown Trout, those in the lochs averaging about a third of a pound;-those in the stream, and particularly high up, above Loch Kingie, vary more in weight, many being smaller, but many also running to a much larger size. The lochs are celebrated as containing Great Lake Trout (Salmo ferox) which not unfrequently attain to a great weight there. It was for the purpose of trying my luck at these big fellows, that I went with a friend, in July, 1856, to Tomdoun, Tomindoun, or Tomadoun (the name is thus indifferently written, not an unfrequent occurrence in the Highlands, where they are not very particular about their spelling), a comfortable road-side inn, about five hundred yards 
from the river, and some three miles above Loch Garry, kept by Mr Robinson, a worthy man, who, as well as his wife, does all that he can to promote the comfort of his guests, and told me "he liked to see gentlemen have their sport satisfactory and peaceable." It was somewhat too late in the year, we were told, for much sport to be expected, so far as the Lake Trout were concerned; but under the auspices of John Cameron, whom we had brought with us from Invergarry-a very handy and decent fellow, and withal so fond of fishing that he has earned for himself the soubriquet of "The Cormorant"-we determined to have a trial at all events. We accordingly set to work trailing in the lochs (using simple spinning-tackle like that described in page 9 et seq.) with a parr or small trout for bait, and having a line (about thirty or forty yards) out on either side of the stern, whilst the boat was rowed slowly up and down over the most likely parts of the water. It seemed at first that the fears which had been expressed with reference to the lateness of the season were likely to prove correct, for during the first two days the result of our trailing was only some four or five dozen Brown Trout, running from about a quarter of a pound to a pound and a half. As this was 
not very lively work, I used in the mornings, before we started together for the regular business of the day, to vary the sport by fly-fishing, or spinning from the shore with a small bait, or killdevil, the pools below the house, picking up thus a good many Trout, including some nice ones of from one to two pounds.

Those parts at the heads and tails of the lochs, where the water was too confined or shallow for trailing, I used to spin over by casting out of the boat in the usual way, a plan which I found answer very well. On one occasion, at the tail of Loch Polery, in which we had been trailing, we saw a Salmon leap, as they not unfrequently do when they have surmounted the difficulties of the upward navigation, and find themselves in still water. Having my line all ready (with a gutta-percha kill-devil on, as it happened), I threw over the place where he had shewn himself. The bait was instantly taken, as I conceived of course, by the same fish, and away he went with it. Had all been clear, I have no doubt I could have killed him, but, unluckily, the outlet into the shallow broken water, into which we could not have followed him, was so near, and he shewed such an evident inclination to make for it, that I was 
obliged to employ greater force than I should otherwise have done, in order to try to turn his head away from it. At first I thought I should have succeeded, but unfortunately the hold gave, and I had the mortification of seeing him execute a preliminary flourish of derision, throwing himself out of the water, and exhibiting his full size, that of at least a twelve-pounder, as he surged off to look for quieter quarters. It is somewhat remarkable, that this fish, as my friend and J. Cameron both positively declared, was not the Salmon which had shewn himself just before, but a Salmo ferox. My own sight is not sufficiently good to enable me to express a decided opinion, but my impression is that they were right, and that the fish was a different one, being larger, and darker-coloured. Besides the spimning-rod, I always had a fly-rod at hand in the boat, with which I used to catch a good number of brown Trout in the runs at odd times. Just above Loch Kingie, for instance, I remember catching in a very short time about three dozen, one of them being two pounds and a quarter, a very bonnie fish. The greater part of these I caught just at the head of Loch Kingie, wading in with only a shirt on, tucked up pretty high, when, what with 
killing "clegs" (horse-flies), the number of which was only equalled by their determination and ferocity, and getting in my fish, my hands were pretty well occupied.

We had been thus engaged for the best part of four days, leading pleasant lives enough, though the weather was somewhat unfavourable, but on the whole beginning to despair of getting hold of one of the big fellows. On the afternoon of the fourth day we halted in a wooded bay on the West shore of Loch Garry, a delightfully pretty and sheltered spot, where, whilst we lounged away the hour we did not then so much grudge for luncheon, John Cameron practically explained the mysteries of ember-cooking fish, which I have before mentioned, a couple of Trout of about a pound each serving as subjects for the lecture. Luncheon over, before yielding myself to that pipe of pipes which succeeds such a repast, perhaps the highest state of pure physical enjoyment of which man is susceptible, I took stock of my remaining spimning tackle. I then found it had suffered so much from the nibbling of the small Trout, that the flight of hooks I had up was the only one of the proper size left, and, to make matters worse, the single gut attached to this was frayed half in two 
close by the lip-hook. However, as we had not had a run from a big fish in trailing, and it was getting late, I thought I would just take the chance, and continue fishing with it. At length, after we had been long, over-long, stretched on the heather, watching the smoke of our pipes, as it curled up among the birch-trees to the blue overhead, each awaiting from the other the unwelcome signal for a move, our eyes met, and the fact that it was time to be at work again was tacitly but mutually acknowledged. He has some pleasant reminiscences, who can look back to many halfhours of such unmixed tranquil enjoyment as that which I, at least, experienced before the sense of duty prevailed, and we forced ourselves away for a fresh start. Having rebaited our hooks with small trout, we now pulled over to the opposite side of the loch, and had only taken one or two turns up and down the likely part of it, when about half-past six I felt a tug from what I soon found was very different from anything that I had had on before, and away he went with the bait,away-away-straight from the stern of the boat, as if there was to be no end to his going. I immediately sung out to Cameron to back the boat after him, but before he could get any way upon 
her, she being a heavy square-sterned coble, the fish had run out the whole of my line, nearly a hundred yards, with the exception of one turn and a half round the reel. I had been giving it to him more and more reluctantly for some time, though, knowing the state of my gut, I did not dare to put any strain upon it, and was all ready, if he persisted, to let him have rod and all, by throwing it into the water, as soon as the line was exhausted. However, at last, I ventured on just as much gently persuasive force as I thought my trace would bear, and the move fortunately succeeded. Back he turned, and away he came again, straight for the boat, much faster than I could wind up, though Cameron backed me by pulling his best. Of course the line became perfectly slack, and I had made up my mind he was off, when a gradual tightening of it told me, to my relief, that he was still all right, and in a few seconds more I had him under command again. This second pull he resented by another tremendous rush in the direction he had at first taken, and again he ran out almost the whole of my line. As I had however by this time to some extent "taken his measure," and he was not quite so fresh as he was at first, I ventured to check him 
a little sooner, with a view of getting him somewhat better in hand. Three or four such determined rushes he made, only gradually relaxing in his efforts, and returning after each in a manner which was anything but pleasant at the time. Every now and then he would shew his head above water as he came up to have a look round, when Cameron greeted it with "God bless me, what n'a head!" Then would follow in due succession his dorsal fin and tail as he turned over to go below again. Cameron's excitement was too great for any variety in his expletives. It was always, "God bless me, what n'a back-fin a got!" "God bless me, what n'a tail!" After playing him for about half-an-hour, he gradually became less and less disinclined to listen to reason, and we set about finding a place to land him in. We looked at two or three as we coasted quietly along, but there were always rocks or something in the way, which made them objectionable, and at last we paddled across, as fast as the fish would follow, to a small island, the shore of which was smooth, and rose gradually to the water's edge, near the head of the loch. Here Cameron ran the boat up, and I carefully jumped on shore. The ground was all clear, and I took the fish up to a convenient spot 
away from the boat, and brought him quietly up into shallow water, when John Cameron waded in round him, and, getting his hands well under his gills, hauled him bodily out, and with a "God bless me, what n'a fish!" brought him on shore in his arms. I had entreated him to employ the gaff, but he seemed so uncertain as to its use, and so confident of being able to do it in his own way, that I let him "gang his ain gait." The fish proved to be a magnificent male Salmo ferox, which our steelyards agreed in returning about two ounces under twenty pounds. His dimensions were,-length, two feet eight inches and threequarters; girth, one foot ten inches and a half. Anything like his condition I never saw, but it may be judged of by the fact that he was compared by the first three people we met, to a pig, a whale, and a pair of bellows.

On looking to see how he had been hooked, I found that the lower part of the flight of hooks had caught him in the side of the mouth, but that the lip-hook had also, no doubt as he went away in one of his long rushes, got fast in one of his gill-covers, behind the eye. Thus I had throughout been labouring under the disadvantage of having a cross-pull on him, which, coupled with 
the defective state of my gut, the fault in which was just at that critical place, made it a matter of wonder that I ever succeeded in landing him. Possibly however the effect of this cross-pull may have been advantageous in preventing him from leaping, had he done which, I think we must, in all probability, have parted company.

I should mention that, though there are one or two boats, such as they are, on Loch Garry and Loch Polery, and those lochs, with the part of the river between Loch Kingie and Loch Garry, may be fished by any one staying at Tomdoun; yet a boat cannot be got upon Loch Kingie (in which the Salmo ferox is said to be more numerous than in either of the other lochs) without the express leave of Mr Ellice of Glen Coich, who however, I believe, obligingly permits rod-fishing from the shore. When we were there, Mr Ellice was absent from home, and his keeper, who had been at some trouble to get the deer down near the loch, feared that bringing a boat across might disturb them, so we left Loch Kingie without giving it a fair trial, for though it is comparatively small, and very deep towards the centre, yet as it is rather shallow and weedy on one 
side, and awkward to get at on the other, it is almost useless to attempt spinning it from the shore.

A shooting-lodge, which I occupied with some friends for a couple of seasons close to a sea-loch, in Ross-shire, has been mentioned elsewhere in these pages. One of the principal dependents (in his own estimation) attached to it was a stocky little yellow terrier, not smooth, nor of the shaggiest, but of a kind of intermediate roughness, whose two chief personal characteristics were a singular bunch of light yellow hair, about an inch and a half long, projecting from the outer corner of each eye, which gave him a very grotesque appearance; and the determination with which, never keeping more than three legs in work at the same time (as is the habit of such dogs) he changed from one hind leg to the other at every two steps when on the march.

Although he took a great interest in all fieldsports in which he had an opportunity of joining, yet fishing was the one which possessed for him the most particular attractions, and in which he principally excelled. His proper owner, who resided at a considerable distance, had formerly lent him to the keeper, when, having once tasted 
the delights of a free piscatorial life, he could not only not be induced to return, but, if taken home to his master, soon found his way back to the quarters where he could enjoy his favourite sport ad libitum. It mattered very little to him what kind of fishing was the order of the day, so long as he was permitted to take a part in it. He soon found out what it was to be, whether up the river for Salmon, or down the loch for sea-fish, and was always the first on the road towards the river, or in the boat when sea-fishing was determined on, as the case might be. Many a rough day he had of it-sitting in the bow or stern-sheets, wherever there happened to be room for himdrenched with rain and spray, and perhaps half frozen by a biting wind. But all this was endured, just as his human friends endured it, for the sake of the sport, which seemed to make up for all discomforts. Great was his excitement when a Salmon was hooked, and profound the attention with which (head on one side and ears cocked) he watched all the subsequent proceedings-the Salmon's rushes-his leaps-his gradual approach to the shore-perhaps an unsuccessful attempt to gaff him (for the gillies there were not very certain hands at the work), until at length the crown- 
ing effort was made, and the fish landed safely on terra firma. He was then a proud and a happy dog. He had done his work well in his own opinion, and evidently considered himself to be off duty for a time, and entitled, in common with ourselves, to take a rest and divert himself, which, after inspecting the fish, and superintending the process of weighing it, he accordingly set about doing in his own way, that is, instead of smoking a pipe over it as we did, he, after a preliminary stretch and roll on the heather, took out his relaxation in a hunt (not however often attended with much success) after field-mice.

Of sea-fishing too he was very fond, and, when hand-lines were employed, would look orer the side as a line was hauled in, and await the appearance of the up-coming fish with the keenest interest. The method I have elsewhere described of trailing with a number of flies on the same line he never seemed thoroughly to understand, apparently considering that one, or at the most two, fish at a time was as much as could possibly be expected, and when a string of about a dozen came in one after the other, he got into a state of perfectly bewildered excitement.

But what he peculiarly delighted in was fishing 
CH. IX.] FISHING ON HIS OWN ACCOUNT.

on his own account. The fish required for the consumption of the house were cleaned and washed in the sea-loch opposite to it; and, attracted by the offal which resulted from that process, large Cod used constantly to come in, two and three at a time, coasting quietly along, and venturing close to the shore, where there was scarcely depth of water to cover them, almost regardless of the presence of bystanders. Here of an evening, after we had done our day's work, our friend used to take his stand, perhaps occupying a commanding position on one of the steppingstones which formed a rough pier for the purpose of embarkation, on the look-out for the Cod. Although he generally saw them when they were at some little distance from the shore, yet, if they seemed to be coming pretty straight towards him, he rarely made any demonstration until they were well within reach and he had a fair chance at them. Then in he went with a rush. There was a tussle, a diving, a gripping, and a blowing, and then gradually he emerged, struggling with and dragging after him the unwieldy and reluctant form of a big helpless-looking Cod.

These fish rarely (if ever) venture in so close and boldly, except when badly fed and out of 
condition; and although those which were thus caught would, when in proper condition, have been of a very good size (for even then they weighed as much as ten or twelve pounds each), yet they were consequently, for the most part, poor, ugly, ill-shaped brutes, and so little fit for the table, that, with the exception of a few which the gillies took home to be salted, such as could be rescued in time were put back again,-a course of proceeding by no means to the taste of the Captor, who viewed it with marked dissatisfaction, evidently shewing by his manner that he considered we had no right whatever to interfere, and saying as plainly as a dog could speak, "I never put back any of your fish. Why on earth should you meddle with mine!" I noticed with some surprise that several of those which had been thus reprieved seemed nothing daunted by the rough reception they had experienced, and might be seen returning after a few minutes to prosecute their search for the offal, as if nothing had happened.

The keeper told me that, when they were alone together, the dog had often landed Salmon for him: as however we had human and mechanical aids at hand, we never availed ourselves of his services for that purpose. 


\section{CHAPTER $X$.}

Eels held in abhorrence by Scotch-Scruples overcome-Foxhunter-"Snakes and Puddock-stools"-Deformed Trout -Brown Trout in Glomack - in the Findhorn - "Great spotted Ling" - Singular effect of fish-diet-_"Sour Skate" -Queer fancy of Cow.

HELS are regarded by the Scotch generally with the greatest possible aversion, amounting to a loathing quite as great as they would feel towards snakes, to which they seem to consider them closely akin. This is really a misfortune, for there is scarcely a loch or river in Scotland, which does not swarm with them-the lochs particularly; and an excellent and easily attainable article of food is thus lost to them. They do not, however, appear to entertain the same repugnance to Conger-eels, which are not unfrequently eaten by the fishermen and other's living along the coast.

Strong as this prejudice is, I have yet known one or two instances when inhabitants of the Highlands have been induced to overcome it, and have generally found that when they had once 
134 EELS HELD IN ABHORRENCE BY SCOTCH. [PART I. tasted the forbidden food (like Charles Lamb's Ho-ti and Bo-bo, in the case of pork), they needed no inducement to continue the same course of diet. One of these instances was rather amusing. Having, with some friends, taken a moor in Argyleshire a few years ago, we used to obtain from the loch hard by the lodge a good supply of eels, for the most part taken with a wire eel-pot or trap which we had been at the trouble of importing from England. At the sight of these our old "Fox-hunter" (whose avocations I will mention presently) exhibited such extreme and ludicrous horror, that our English servants, who rather took a pleasure in "baiting" him, declared one day that he should have no dinner till he had eaten an Eel. The poor old Fox-hunter at first affected to treat it as a joke, and then, finding that that would not do, endeavoured to move them to pity. However, it was of no use,--they were bent on his conversion, and resolutely locked up his dinner. The unfortunate victim held out for some hours, but then his increasing appetite, and the savoury smell of the eel, which he acknowledged was good, were together too much for him, and he gave in. The eel was set before him, when, strange to say, he not only finished it without manifesting any repug- 
CH. X.] SCRUPLES OVERCOME-“FOX-HUNTER." 135

nance, but (like Oliver Twist). asked for more, and was ever afterwards happy to avail himself of any chance that threw an odd one in his way.

As it may seem strange to English ears to hear that a fox-hunter should have been in a position to be thus cavalierly treated in respect of meats, it may be as well to inform the uninitiated that a "fox-hunter" in the Highlands means a person who is paid by the neighbouring farmers to rid the country of foxes. This he does in all kinds of unhandsome ways, by gun, by trap, and sometimes by a motley pack of "hounds" by which they are run to earth, being afterwards dug out or otherwise disposed of, if they have escaped being shot in transitu. The lively description in Guy Mannering of a hunt of this kind will be vividly in the recollection of all readers of Sir Walter Scott.

Our Fox-hunter, during the summer and autumn months, when he was not busy about his craft, gave us his valuable services as gamekeeper, dog-feeder, and general factotum as well on water as land, assisting on the former in the boats when required. This last occupation however he never took kindly to, considering it, I fancy, rather below his dignity, and looking upon 
fishing in general as an ignoble and degrading sport rather than otherwise. Shooting was his delight, when engaged about which I never saw a day too long, or a hill too high or "coarse" for him, though upwards of sixty seasons had passed over his head. It was a favourite boast of his that he had been forty-three years a fox-hunter, and never had missed a fair shot at a fox at forty yards,"Forrty yarrds, Sirr-yees."

Besides Eels we used, whenever we could get them, to indulge in mushrooms, which are also objects of suspicion to Highlanders, and generally considered by them utterly unfit for food. One of our party too was curious in the matter of funguses, and, not confining himself to the orthodox mushroom, used to bring in all kinds of "agarics and fungi" of as questionable appearance as those described in Shelley's Sensitive plant, all of which he insisted on having dressed, and made a point of doing full justice to. I was once induced (in an evil hour) to make an essay on a puff-ball, being assured that it would be quite as good as the common mushroom. Anything so nasty I never tasted. From its appearance and consistency I could well have imagined it to be broiled slug, and its taste was, to my palate, very 
CH. X.] DEFORMED TROUT-TROUT IN GLOMACH. 137

much what a slug fed on decayed regetables might have been. But let the puff-balls be by-gones, and "revenons à nos moutons." After we had vacated our house, and the owner had returned to it, she one day asked the gardener something about our cuisine, upon which he answered, "Eh! they eat snakes and puddock-stools; just vermin, Mrs S."

In a small burn running into Loch Duich (Ross-shire) I caught with a fly (in 1857) a curiously deformed Trout, his lower jaw being of the usual length, but the upper one terminating abruptly close to the eyes, in the same manner as the one delineated by Yarrell in his book on British fishes, Vol. II. p. 108, except that in this instance the deformity was more exaggerated. He weighed about a third of a pound.

Some notion of the number of Brown Trout to be occasionally met with in parts of the Highlands may be gathered from the following incident. In the same part of the country, a short distance above the grand fall of the Glomach (a visit to which by the way, throwing itself, as it does, some three hundred and sixty feet in one unbroken leap, would be alone almost sufficient to repay a journey to Scotland), I took up a rod which happened to 
138 AN AFTERNOON ON THE FINDHORN. [PAR'T I.

be standing ready at a tent set up there by us as an occasional sleeping-place and house of call, and, going down to a pool about eighty yards below it, caught in less than half-an-hour, without moving from my place, thirty-one Trout. They were mostly about Pilchard-size, with the exception of one, which weighed a pound and a quarter. I rose him the first throw, but did not move him again until I had caught twenty-nine. He was an ugly disgraziato, who looked as if he had his back broken in his infancy. Had I changed my ground, so as to fish more water, no doubt I should have added to the score, but I wished, from curiosity, to see what I could do whilst standing in that one spot. Apparently I might have caught as many more there, had I continued fishing, but I was then obliged to give up, having other work in hand.

On another occasion, after about three hours and a half's fishing in the Findhorn, I left off in consequence of my basket being crammed full, and returned to the Lodge, when I found my take amounted to a hundred and fifteen, weighing twenty-six and a half pounds. I had been fishing under difficulties, having broken my rod in the outset. In addition to this, I had to carry my own 
fish, no slight weight at last, and as I was mostly wading, and had no net, I lost a great number. Under favourable circumstances, and fishing the whole day, I have no doubt but that I could have easily doubled, if not trebled, the score.

The following saying, which is current amongst the fishermen on the western coast of Scotland is, from its originality and grand suggestiveness, not without its merits, and, I think, worthy of preservation: "Seven Sprats go to feed a Herring; seven Herrings go to feed a Salmon; seven Salmon go to feed a Seal; seven Seals go to feed a Whale; seven Whales go to feed a Kennan-craw; and seven Kennan-craws go to feed The Great Spotted LING, which lives on the other side of the whole world."

An old gillie in service at our shooting-quarters used to say that the only fish he could eat were Dog-fish and Salmon, "with may be a Sea-Trout," declaring that all the rest made his "skin swell." How this swelling developed itself, whether in head, body, arms, or legs, I never could exactly make out, for he seemed to be rather afraid of being "chaffed" on the point, if he entered more fully into particulars. However, he was evidently quite in earnest, and seemed thoroughly impress- 
140 ODD EFFECT OF FISII DIET-_"SOUR SKATE." [PART I.

ed with the conviction that any other kinds of fish would have the mysterious and umpleasant effect he attributed to them.

We have heard of strange modes of dressing food in use amongst uncivilised tribes, but I doubt whether any "traveller's tales" have ventured on the description of one more eccentric than the following mode of preparing Skate for the table, the ingenuity of which is only surpassed by its exceeding nastiness, and which I was not a little taken aback at finding adopted in a corner of our own enlightened kingdom. The fish, when cleaned (a somewhat unnecessary preliminary one would think), is buried in wet horse-dung, where it is allowed to soak for about twenty-four hours. It is then taken out, (washed, we hope), and boiled for the table, where it is presented as "Sour Skate""a varra deleecious dish," according to my informant, who evidently spoke of it with considerable gusto. If, as has been asserted, the progress of the gastronomic art affords a fair test by which to estimate the march of civilization, what conclusion might not be drawn from this little circumstance with regard to our friends of the Hebrides?

If some of the Scotch have strange fancies in 
the matter of diet, their cattle, it would seem, occasionally take after them in this respect. I was one day fishing the Ness out of a boat, when I noticed a cow inquisitively examining some things which I had left by the water-side. On landing I found she had been influenced by other motives than those of mere curiosity, having eaten up the whole of one side (the button half) of a new macintosh. Happening shortly afterwards to meet the miller whose property she was, I exhibited to him the mangled evidence of her misdeeds, expecting at least to meet with something like sympathy for my loss. His sympathies were however all on the other side. He surveyed it for some time in silence and with an air of dejection, and then simply exclaimed, "Eh, but she'll no be the better o' the buttons!" 



\section{P A R T II.}

\section{Matural gifotory.}





\section{NATURAL HISTORY.}

\section{CHAPTER I.}

Nest of Mason Wasp-Larvoe under Water-lity LeavesBirds misled by unseasonable weather-Tameness of Robins-Tameness of Wood-pigeon during breedingseason-of White-throat-of Partridge-Tame GullsTameness of Gulls in general-Their fight variable wccording to weather.

A $\mathrm{N}$ unusually favourable opportunity was af1 forded me a few years ago of observing the mode adopted by the Mason Wasp (Odynerus parietinus?) in the construction of its nest, and the disposition of its larvæ with the food provided for their sustenance.

I was sitting in a somewhat dilapidated summer-house, when I noticed one of these insects busily engaged in endeavouring to insinuate a white caterpillar, about two-thirds of an inch long, into a hole in the upright skirting. From the smallness of the aperture it was a work of 
some difficulty, but he at length succeeded in effecting his object. The next day the same manouvre was repeated and another caterpillar gradually worked into the hole. As I happened to be leaving the neighbourhood on the following day, and was curious to ascertain how these prisoners had been stowed away, I carefully stripped off the skirting adjoining the hole, when the secrets of the prison-house were at once revealed. The hole communicated with the bottom of a perpendicular opening in the wood-work some three inches in length. From the top of this was suspended by a slender filament an egg, with and below which was immured a caterpillar still alive, but apparently in a semi-torpid state. These were secured by a flooring of cement, from which was suspended another egg, having for company another living caterpillar. Then came another flooring-then another egg and caterpillar-then another flooring, and so on; four cells having been thus completed one above another, each containing its egg, and the caterpillar destined to become food for the young wasp when hatched. The caterpillars were all in the same state of semitorpidity, these insects having, in common with others, as the Sphex and Pompilus, the marvellous 
power, by stinging it is supposed-though I believe that some of these insects never use their stings for purposes of defence-of partially deadening (though without destroying) the vital principle of insects stored up as food for their young. I much regretted being unable to watch the progress of this interesting piece of domestic economy.

Although this insect exactly resembled the Odynerus parietinus, yet I hesitate to express a positive opinion that it was of that species, as the Parictinus appears-so far as the knowledge at present possessed of its habits extends - to provide for its young a number of small caterpillars, instead of one large one for each as in the present instance. That it may, however, thus adapt itself to circumstances in the selection of the food to be stored up, is at least possible; and the fact, if ascertained, would only add another to the numberless instances in which the marvellous instinct of insects is displayed ${ }^{1}$.

1 This method of providing food for their young is not confined to the Mason Wasps-it being adopted also by the Sphegido, $\boldsymbol{P}$ ompilida, and others-and appear's to prevail very widely throughout the world. Darwin, in his interesting $\mathrm{Na}$ turalist's Voyage round the World, mentions the same thing as happening, under very similar circumstances, at Rio de 
Another ingeniously constructed infant nursery came under my notice whilst on a visit to a friend near Marlow. Having observed that several of the water-lily leaves floating on the surface of a moat were perforated by cleanly cut circular holes, nearly the size of a florin, I was induced to turn up these and some of the adjacent leaves, when

Janeiro, and refers to a paper in the Journal of the Asiatic Society of Bengal, by Lieut. Hutton, who describes a kind of Sphex and also a Pompitus which construct their cells side by side, and store them with spiders.

Kirby and Spence assert (apparently on the authority of Bonnet) that the Mason Wasp "not only encloses a living caterpillar along with its eggs in the cell, which it carefully closes, but at the expiration of a few days, when the young grub has appeared and consumed its provision, reopens the nest, incloses a second caterpillar, and again shuts the mouth." Can it be that the caterpillars which were thus seen to be brought to the nest on successive days, and supposed to be for the eggrs collectively, may have been, as in the case I have mentioned, each destined for its particular egg? In the nest I have described I am satisfied that it was impossible for the parent Wasp to communicate with the upper cells except by destroying those below it.

Further notices of similar insects will be found in Gosse's Letters from Alabama, page 244, where there is also given an illustration representing a Pelopceus flavipes in the act of carrying a spider to its cell ; and in Sir James E. Tennent's Ceylon, r. 256. According to this latter author the Sphegidoe there lay their eggs in the pupæ of other insects before depositing them in the cells. 
the use to which the missing pieces had been applied was made apparent. They were adhering flat-wise to the under sides of the leaves, and from their puffy appearance, evidently formed coverings to some bulky substances. These, on my stripping off their covers, proved to be large fat grubs (apparently at least two thirds of an inch long) each comfortably tucked in by his green sheet, which was closely cemented to the leaf forming the bed under which he reposed.

As to the insect to which these larvæ owed their existence I must confess myself much in the dark. Not having, at the time when I discovered them, paid as much attention as I ought to this branch of Natural History, I was not then aware that there was anything very uncommon in this disposition of the larvæ, and in consequence unfortunately neglected to secure a specimen or make accurate measurements. Since then I have spared no pains to ascertain what the insect was, and have applied for information on the subject to some of our most distinguished entomologists, hitherto however, strange to say, without success. Divers species, Donacia, Hydrocampa stagnalis, Nymphosolis, \&c. \&c. have been suggested, but in no instance does the manner in which the 
egg is deposited quite tally with the one above mentioned. From the similarity of the Hydrocampa potamogeta's arrangements (described by Réaumur-see Rennie's Insect Architecture, p. 154. Murray, 1857) I should however conclude that the one in question was of that family. The Caterpillar, indeed, appeared to me thicker than I should expect to find that of a Hydrocampa, but my eyes may have thus far deceived me.

From the mistakes which birds occasionally make with regard to the time of incubation, it would appear that their instinct affords them no other guide to the approach of summer, than that of the increasing warmth of the temperature. A remarkable proof of this occurred in the winter of $1857-8$, when two of the chimnies of a house in the Isle of Wight, where I was staying at the time, were between Christmas and New Year's Day blocked up by Jackdaws' nests, which must have been constructed then, as the chimnies had been swept less than a fortnight before. The birds were indeed, I believe, actually seen carrying in materials. In these nests, besides the quantity of sticks and rubbish of which they usually consist, the jackdaws had taken the odd fancy to insert some pieces of glass, whether for use or 
ornament did not appear. Had they been allowed to continue their operations they would have been soon undeceived by the setting in of a hard frost accompanied by heavy snow, and reduced, in spite of their warm situations, to the state of Cowper's birds:

"Back into their nests they paddled, Themselves were chilled, their eggs were addled."

The extraordinary freshness of the foliage, \&c. at that period was however quite sufficient to mislead any simple-minded bird. For instance, within a day or two of the same time I found, in a somewhat exposed situation, a blackberry-bush, having at once upon it flowers in full bloom, and green, ripening, and ripe fruit, quite reminding one of Homer's description of the vines in Alcinous' garden, Od. H. 117-126. Whilst we were thus enjoying a second summer in England, the weather was, in the south of France, Italy, Portugal, Malta, and the East, unusually severe. From a friend, who had gone to Pau to escape the rigours of the English winter, I received, while the Jackdaws were thus building in our chimnies, and the blackberries still in full autumnal vigour, a letter expressing his regret that he had not taken his skates with him; and again, about the third week 
in January, when he had migrated to Rome in hopes of finding the warm weather he had vainly sought at Pau, another, in which he said, "The ice about the fountains, \&c. is just beginning to shew signs of thawing." During all the early part of the winter the weather had been, in the south of England, remarkably dry.

There were about the same house a few years ago a pair of Robins, who were more than usually tame, and whose determination to identify themselves with the family, and make themselves at home, was not a little amusing. They used regularly to come into the dining-room at breakfast time, and help themselves to whaterer they fancied, modestly confining themselves, however, generally to the sidetable, where the tail of one was often to be seen appearing above a pie-dish, the rest of him being busily engaged inside, "pegging away" at a hardboiled egg, or something nice of the kind. When the spring came on they commenced a regular contest with the housemaids, of which the drawing-rooms formed the scene of action; the robins insisting that they would build there, and Fanny and Co. insisting that they should not. "Expelles furcâ, tamen usque recurrent." As soon as a nest was commenced in one place, in went Fanny's 
broom (her "furca") or her fingers, and out it came, when they immediately looked out another place and began again. Three or four nests had been thus commenced, and as rudely put a stop to, when the birds, seeing the mistake they had committed in building within the housemaids' reach, pitched on a spot where they might well think the nest would be secure from molestation, in a corner, over one of the curtain-rods. Here they laboured undisturbed, except that the housemaids still endeavoured to hinder their operations by keeping the windows shut as much as possible, and giving chase to them whenever they found them in the room. I have seen the housemaid in vain attempting to drive one out, as he kept hopping about, just out of her reach, with a piece of moss or leaf in his mouth destined for the nest, to which he at length succeeded in carrying it. In spite of this determined opposition they managed, by great exertions, to get a rough nest finished in time to receive Madame's first egg. They must then have considered their triumph complete, but, alas! that very day was the one fixed upon for the general half-yearly "cleaning." The doom of the nest was sealed, and a short time afterwards I was sorry to see it, looking very 
disconsolate with its single egg, on a table in the hall. I did not see either of the birds in the drawing-room afterwards. They probably gave up settling there as a "bad job," and went to look out some more favoured place, where housemaids, with their brooms, pails, et hoc genus omne, were unlikely to trouble them. I wonder what lying-in-hospital poor Madame found for her remaining eggs.

The tameness of the Woodpigeon during the breeding season presents a remarkable contrast to his extreme wildness at other seasons of the year. In the winter, saving the Curlew, I scarcely know a shyer bird, or one who takes generally better care of himself. If you endeavour to approach one in a tree, he almost invariably flies off so as to keep it between yourself and him, and thus often saves himself from the chance of a shot. In the spring, however, you see the Woodpigeon quietly walking about your pleasure-grounds close to the house, or sitting unconcerned on a low tree, and cooing, within a few yards of you, crossing you as he leaves it, or coming straight over your head with a flight betokening nothing of alarm or haste, but probably executing, as he does it, one of those elegant movements peculiar to that 
season, raising himself on the wing and gracefully subsiding again, as if his ordinary flight was too low and commonplace for his buoyant spirits.

But though the effect of the breeding-season in counteracting the natural wildness of the bird is peculiarly exemplified in the case of the Woodpigeon, it is by no means confined to that species. Many appear to be more or less sensible of its genial influence.

I remember finding, when a boy, the nest of a White-throat, which she had constructed in the stem of a tall hemlock. Whilst engaged in the work of incubation, she appeared to be perfectly devoid of fear, and would not only permit my sister and myself to stroke her on her nest, but would actually take food from our hands, thus proving that her tameness was not merely the result of that mysterious orópy - that love for her young, which in the female seems to annihilate all sense of fear, but that, apart from it, she had lost that dread of man by which she would at other times have been more or less influenced.

The following remarkable anecdote may not be considered out of place here, although it is not improbable that in this instance the bird was actuated simply by $\sigma \tau o ́ \rho \gamma \eta$. 
A Partridge, which had her nest in a hedgerow close to a footpath leading to a farm-house in the Isle of Wight, sat there upon thirteen eggs, and appeared so little disturbed by the presence of the passers-by, that the farmer one day, from curiosity, put his hand down to see if she would permit him to touch her. The bird however flew off, but, doing so hastily, became caught in the briars surrounding the nest, and he took her up. He then perceived that her crop had been ripped up by a thorn, and to such an extent that its contents escaped through the rent. He took the bird into the house, where his wife, with the assistance of her maid, carefully sewed up, one after another, the wounds in the inner and outer skins of the crop, rubbed in a little salt butter by way of a salve, and set the bird at liberty. Away she flew,-but within a very short time, in spite of all that had occurred, she had actually returned to her eggs, of which, in due time, she succeeded in hatching twelve.

This story appears at first sight so improbable, that it is perhaps as well for me to state that I have satisfied myself by personal inquiries as to its perfect accuracy.

I have known of two instances in which Gulls, 
which had been caught young, and tamed, have continued to keep up their intimacy with those who reared them, after they had gained the full use of their wings and were at perfect liberty; though they took advantage of it to go away every year at the breeding-season, and might have been supposed to have entirely resumed their natural habits. Both of these instances occurred in the Isle of Wight-one at Calbourne, where I well remember "old Phil," as he was called, year after year, sailing over the village-green, and alighting on a low wall at the grocer's shop, from which he used to be fed with bits of cheese, of which he was very fond, and other similar dainties. The other instance was near Sea View, where, I am informed, the gull used to return in the same way, his former tameness not appearing to have been at all affected by his temporary retirement into wild life. Not the least remarkable part of the history of these birds is that, during the breeding-season, each of them occasionally brought his mate with him to introduce her to his old friends, and to invite her to partake of their hospitality. I don't think, indeed, that "old Phil" ever prevailed on his better half to come and share his cheese, but she used to keep him company into the village, 
158 tameness of GULlS in General. [PART iI.

and sometimes amuse herself in a pond hard by, whilst he went to pay his accustomed visit to the grocer. In the other case, near Sea View, my informant tells me the wild Gull used to come up and feed with the tame one under his dining-room windows, though she would not approach quite close so long as any one was visible at them, but sat on the grass-plat a short distance off, or hovered round until the coast seemed clear.

Perhaps there is naturally less fear of man entertained by Gulls than by most other birds. One can scarcely be for a few hours at sea, or by the water in a harbour-town, without some of them, from curiosity or carelessness, coming round so close to one as to afford sufficient proof of this. Last year (1858), whilst fishing at some distance outside the harbour at Stornoway, I threw over, foul-hooked, and brought into the boat, with a short cuddy rod and line, which happened to be on board, two Gulls, as they flew round close to us, allured by the hope of a share in our fish. The first, when released, not having exhibited the slightest fear, but continued to hover round us, closer, if anything, than before, as if he fancied he had then a special claim to our attention, I thought, on catching the second, I would see to 
what extent he might be disposed to entertain friendly relations towards us. Accordingly, I took him in my lap, and offered him some nice bits of fish. At first he professed to be angry, and pecked at my fingers instead of the fish, as if to ask whether I thought it possible that he would condescend to accept my donations under restraint. However, having accidentally-onpurpose got hold of a piece of the fish, down it went; and, apparently thinking that under the circumstances he might do worse, he set to work with no ill-will or appetite, and soon got through a good part of a haddock. Then however, whether from eating too fast, or from his position being uncomfortable, or perhaps from a feeling that he had been compromising his dignity-fortunately for me I had a pair of macintosh overalls on-up it all came again. As I had been for some time engaged in feeding this nursling, who thus repaid me by "puking in his nurse's arms," and the fish were biting freely, I left him to his own devices, and away he went. On regaining his liberty however, so far from appearing to resent my compulsory kindness, he rather seemed to wish for a repetition of the same course of treatment, for he continued to fly 
160 GULLS' FLIGHT AN INDEX TO WEATHER. [PART II.

backwards and forwards within a few feet of our heads, as if he thought he had been a fool after all. The captain of one of the Dover and Ostend steamers told me that he had seen a Gull come and take off the taffrail food which had been placed there for him.

Changes of weather may be foretold with considerable accuracy by observing the flight of Gulls, as, after feeding inland, they, according to their invariable custom, wing their way homewards towards evening to their roosting-places in the cliffs; making this transit in fine weather high and in comparative silence, but in bad blustery weather, and before rain, much more noisily and nearer to the ground, merely skirting the tops of the coverts which lie in their course. 


\section{CHAPTER II.}

Do Birds understand what they say? - Anecdotes in pointSand-martins at Weybridge-Swallows killed by Parasites-Swan feeding Cygnets-Cock-turkey as NurseDisposition of Egg-shells in Nests of Partridges, \&c.Eggs of White Pheasant-of Himalayan ditto-Hatching by Pheasants and Hens compared-Two Species of Land Lizards-Large Lizard in Spain-Estremadura-Blak Viper-Fetidness of Common Snake-Snake and Eel.

$\mathrm{T}^{\mathrm{N}}$ a pleasant article contributed to Fraser's Magazine in October, 1857, entitled "Jays and Nutcrackers," are collected some anecdotes of birds, with a view of proving that those brought up in confinement, and taught to speak, in time become acquainted with the meaning of the words which they utter. Now whether such cases as those referred to are merely the result of accidental coincidence; whether, having been taught to associate certain words with certain actions, it is only by rote and mechanically that birds are led to repeat them at the appropriate times, as 
162 DO BIRDS UNDERSTAND WHAT THEY SAY? [PARTII.

they unquestionably do; or whether they ever really understand the meaning of what they say, it would be hard to prove, no matter to what extent instances might be multiplied.

Although I confess I do not give birds credit for so much sense as the author of "Jays and Nutcrackers," yet I will contribute an anecdote, for the accuracy of which I can vouch, and which, so far as it goes, certainly tends to prove his theory.

A Parrot belonging to some friends of mine was generally taken out of the room when the family assembled for prayers, for fear lest he might take it into his head to join irreverently in the responses. One evening however his presence happened to be unnoticed, and he was forgotten. For some time he maintained a decorous silence, but at length, instead of "Amen," out he came with "Cheer boys, cheer." On this the butler was directed to remove him, and had got as far as the door with him, when the bird, perhaps thinking that he had committed himself, and had better apologize, called out, "Sorry I spoke." The overpowering effect on the congregation may be more easily imagined than described. 
The Parrot of a relation of mine also used, whenever he dropped anything he was eating, to say, "Pick up Bobby's crust," being doubtless prompted by the same train of associations, as those which lead another Parrot, which I know well, invariably to say, "Thank you," whenever anything is given to him.

The following story is not a bad one, but all that I can say with regard to its authenticity is, si non è vero, è ben trovato-If it be not true, it deserves to be so for the sake both of master and pupil. Some parrot-fanciers had agreed to meet in a year's time, when each was to shew a bird for a prize, proficiency in talking being by common consent to be the great criterion of merit. On the day appointed all the rest came, each duly bringing his Parrot: one only appeared without his. On being asked why he had not shewn one according to the agreement, he said that he had tried to train one, but that he was such a stupid bird he was quite ashamed to bring him. This excuse was held to be inadmissible. All the others insisted that, stupid or clever, he must be produced, and his master accordingly went off for and returned with him. No sooner was he introduced, than, looking round at the large assemblage of 
birds, he exclaimed, "My G-, what a lot of Parrots!" The prize was immediately voted to him by acclamation.

Whilst waiting for the train one afternoon at Weybridge, I amused myself with watching the Sand Martins, who have there a large establishment on either side of the cutting, and got into conversation with one of the porters about them. On my saying, I supposed that the boys robbed a good many of the nests, he answered, "Oh! Sir, they would if they was allowed, but the birds are such good friends to us, that we won't let any body meddle with them." I fancied at first that he spoke of them as friends in the way of company only, but he explained his meaning to be that the flies about the station would be quite intolerable if they were not cleared off by the Martins, which are always hawking up and down in front of it; adding that even during the few hot days which occurred in the spring before their arrival, the flies were becoming very troublesome. "Now," he said, "we may now and then see one, but that is all."

It was a bright sunny day in July, and the scene was a very lively and interesting one. The mouths of the holes on both sides of the cutting 
were crowded with young Martins-as many perhaps as four or five in each-sunning their barred white breasts, and waiting to be fed: the telegraph wires formed perches, of which advantage was taken by scores of others more advanced in growth, and of old ones reposing after their exertions; while the air was filled with others employed in catering for their families. All of a sudden the young ones retreated into their holes; the wires were deserted, and only a few remained visible describing distant circles. I thought that a Hawk must have made his appearance, but it turned out that the alarm had been caused by two men walking over the heath above, and approaching the holes. The young ones in the holes had, no doubt, felt the jar caused by their tread, and those on the wing, who saw them, had probably given warning, by note, to the others perched on the wires, who could not have seen, nor, I should think, heard their approach.

Two well-authenticated instances have come within my knowledge in which Swallows have, while in the act of flying, fallen to the ground covered with and partly devoured by insects. Of the fact there seemed to be no doubt, but the description of the insects furnished me by my informants 
166 SWANAND YOUNG-TURKEY-COCK-NURSE. [PARTII.

was so vague, that I could do no more than form a conjecture as to their species.

On the Thames last summer I was amused by watching an old Swan feeding her young ones, in what seemed to me a novel and ingenious manner. Sitting on the water with her breast against the bank, she gathered from it the grass as far over as she could reach, and then, turning round her long neck, threw it over her back to the cygnets, who seemed quite up to the mancuvre and were waiting and scrambling for it in the water behind her. My attention was called to it by the fisherman who was with me, and who-though he had lived all his life by the banks of the Thamessaid he had never witnessed it before.

They have in Germany an odd, but useful, plan of pressing the cock Turkey into the service of the nursery, and making him take a share of the work, which he is naturally disposed to leave to his better halves. It is managed in this way:When a "clutch" of eggs is ready, they are placed, with the cock Turkey, in a coop of such small dimensions that he has no choice but to sit upon them. At first he is let out occasionally for a short time to amuse himself, and then put back again, and obliged to continue his work of incu- 
bation. But gradually he becomes deluded into the belief that sitting upon the eggs is his proper métier, and in a day or two not only returns to them of his own accord, but performs all the other duties of the situation in an exemplary manner, hovering the young ones when hatched, and looking after them with as much care as the true mother could have done.

If Partridges', Pheasants', or Grouse's nests be examined, after the young birds have been hatched, it will be found that the half egg-shells which remain are very generally left together in pairs, one being closely fitted into the other, as cups are stowed away in a crockery shop. Ordinarily a small end is packed inside a large one, but this is not always the case, as I have now and then seen two large ends thus united. This operation is not performed by the parent bird, as is proved by its occurrence when the eggs are hatched in boxes so small that she could not possibly get at them to do it if she wished. How the young birds manage it, or why it is done at all, I cannot imagine. Of the fact it is easy for any one to satisfy himself, as I have done. Though I mention Grouse, Pheasants, and Partridges, as the birds in whose nests I have particularly noticed 
168 WHITE PHEASANT-HIMALAYAN DITTO. [PAR'T II.

the egg-shells thus disposed, yet I am far from saying that it is confined to those species.

The eggs of the White Pheasant are smaller and rounder than those of the Common Pheasant, and thus easily distinguishable from them. I have the authority of a keeper, who kept both kinds separate, though in adjoining houses, for saying that they also lay about a fortuight earlier than the common ones. These peculiarities would tend to prove that the two are quite distinct breeds, instead of the white birds, as some persons suppose, being a mere variety-the albinoes of the Common Pheasant. They will mate freely with the Common Pheasant, and the offspring of such union will again breed; pied, white, and ordinarily coloured birds being the result; but, where the breed was originally pure, and they have been kept separate, I have never known an instance (and I have seen them kept so a good many years in succession) where they have produced other than perfectly white birds.

The eggs of the Himalayan Pheasant are also somewhat smaller, rounder, and more richly coloured than those of the Common Pheasant, and come in ( $\mathrm{I}$ am informed by a friend's keeper) about a week or ten days earlier. 
CH. II.] IIATCHING BY PHEASANTS AND HENS. 169

The process of hatching appears to occupy a much shorter time when the sitting mother is a Pheasant, than when the eggs have been put under a Common Fowl. Should you have examined a Pheasant's nest in the morning, and found none of the eggs pecked, you may, on returning to it the same afternoon or evening, find every single one hatched and the young birds clear off. Under a Common Fowl hatching a clutch of Pheasants' eggs is a work of generally from thirty-six to forty-eight hours, and then, in most cases, one or two of the number will prove to be addled or fail to be drawn out. The only way in which I can account for this delay in the hatching, is by supposing the heat of the Pheasant to be more regularly diffused than that of the Fowl. The reason why the Pheasant generally succeeds in bringing to maturity a larger proportion of her eggs than the Fowl, may be that her own are turned by herself, whilst those intrusted to the Fowl are turned by the keeper.

Two Pheasants' nests have been this year (1859) found by a friend's keeper, a large proportion of the eggs in which were smaller than any of the kind that had ever come under my notice, being about the size of those of Magpies'. One contained 
six of these, together with seven of the ordinary size, and the other seven, with five of the ordinary size, all the small ones being of about the same dimensions. The eggs of young birds are often smaller than those of older ones, but these were out of all proportion to the size of the bird. They were besides unusually pointed at the small end. None of these small eggs came to maturity, one of the nests having been forsaken by the old bird, and those of the other, which were placed under a Common Hen, turning out to be addled.

It was formerly generally considered that there was but one species of land Lizard indigenous to this country. I had however for a good while before I was aware that the question had been set at rest by Professor Bell (who in his work on British Reptiles distinguishes the Lacerte agilis from the Zootoca vivipera), and indeed before its publication, entertained a strong suspicion that there were two distinct species, having two or three times seen specimens-such bloated, mottled, ungainly looking beasts, as compared with the bright symmetrical little fellows, who occasionally dart across our path, all life and activity, that I could not bring myself to believe the great difference between them was attri- 
butable merely to age or disease. On mentioning the subject to a station-master on the railway near Wimborne, a very intelligent man, who had ample opportunities for forming an opinion with regard to it (Lizards being extremely abundant in that neighbourhood), he said he "knew positively" that there were two kinds, adding that one of them was poisonous, and the other harmless, the two being easily distinguishable when in motion, as the one then carried its tail erect; the other horizontally. As a proof that one species was poisonous, he assured me that he had seen one spring at, and hang on to, the face of his cat, when shaken off from which he killed it, with one of her "smellers" (whisker-hairs) still in its mouth; and that the cat's head swelled to a great size in consequence of the bite. I give the story as he told it me, for what it may be worth, merely adding my conviction that he stated what he believed to be the fact.

The largest Lizard that I ever saw was in Spain, in the south part of Estremadura. I was riding along a rough bridle-road, in the outskirts of one of the extensive tracts of woodland which form so peculiar a feature of that part of the country, when I was startled by something break- 
ing covert from an adjoining patch of bushes with so loud a rustle that I expected at the very least to see a Hare make her appearance. Instead of this however, to my great surprise, out bolted an enormous Lizard, and away he went across the open with head and tail well up, really a noble looking beast. In length he could not have been much under two feet, if he did not exceed it, but he was chiefly remarkable for the size of his body, which appeared to me to be nearly or quite as large round as the thickest part of a man's arm, his head and tail being quite in proportion.

Having mentioned Estremadura, I may en passant observe that no part of Europe (and I have been over a good part of it) ever struck me as abounding with birds generally to such an extent as that lovely district, or as affording so varied a field for the researches of the Ornithologist.

Some years ago I killed in the Isle of Wight a black Viper, exactly resembling in colour and general appearance the variety figured in Professor Bell's "Reptiles." Being in covert when I came upon him, he availed himself of the circumstance to take refuge in a large hollow hazel- 
stock before I could intercept his retreat. There happened however, unluckily for him, besides the hole by which he had entered at the side of the stock, to be another in the top of it, peering down through which I could distinguish him lying partly coiled up at the bottom. On this I cut a stick with a small fork, and inserting it judiciously through the upper hole, managed to secure him (so far) by pinning him down just behind the head. This of course led to all kinds of contortions on his part with a view of escaping, during one of which, as I expected, he protruded the end of his tail through the side-hole. Being all ready and on the watch for this, I immediately seized it with the other hand, and did not relinquish my hold, until I succeeded in drawing him bodily out by it, which I effected by waiting until his muscles seemed somewhat relaxed, and then giving him a sudden pull, at the same instant removing the fork with my right hand. He was certainly unusually large for a Viper, but unfortunately I did not keep any record of his exact length, and cannot now charge my memory with it.

It is scarcely possible to exaggerate the offensiveness of the odour emitted by the Common 
Snake under provocation. Of its lasting properties I suffered the following unpleasant proof.

Having once found two lying coiled up close together, I disabled them both by grounding the butt of my gun on them, only using it, I think (so far as they were concerned), for that one blow. The butt however became in consequence of it so thoroughly impregnated with their fetid stink, that I could hardly bear to use the gun for weeks afterwards. Were I to say that the smell was disagreeably perceptible on it for a good many months, I believe I should not be in the least over-stating the case.

As one of our garden-men was, a few years ago, passing by a small stream forming the communication between two ponds, his attention was attracted by an unusual splashing in it. On going to the spot, he found this was occasioned by a violent struggle between a Common Snake of some twenty inches in length, and an Eel about twothirds of his own size, which he was using his utmost endeavours to swallow, and had actually succeeded in getting half-way down his throat, while the Eel was still making frantic exertions with the extant part of his tail, in his futile attempts to escape. The man put an end to the 
scene, and the Snake and Eel hors de combat, with a smashing blow across the middle, and brought them up to the house just as they were, with the tail of the Eel still protruding from the Snake's mouth. 


\section{CHAPTER III.}

Strength of Moles-Popular notion respecting them-Badger

-White Fox-Fondness of Cows for bones-Stinling Goat-Fascination of Human Eye on Birds-Charming away Warts-Fancies taken by Animals-SpanielSquirrel-Macaw-Kitten-Cur baptism-Dog's ear for Music-Growling at "strangers" in tea.

THE strength of Moles must be prodigious in proportion to their size. In a summer-house I have seen the track of one distinctly marked by the upheaval and complete displacement of the large round pebbles, which, tightly rammed down together, formed the pavement, and that too right across the centre, where they had been subjected to the greatest additional pressure from the tread of persons passing in and out. There is a popular notion current in the Isle of Wight that these animals ("Wants," as they are there commonly called) work only when the tide is flowing. It is not unfrequently possible to trace these "vulgar errors" to some source, but it would, I fancy, be difficult to do so in this case. 
A large Badger, which had been caught in a covert overhanging one of the cliffs in the Isle of Wight-the only one, by the way, that I ever heard of wild there-was given to a gentleman, who took a fancy to, and wished to tame him. He kept him for some time, but then, finding him troublesome, determined on putting him out of the way, to effect which he gave him, in milk, a large quantity of prussic acid, or what was sold to him as such by a chemist. To his great astonishment however, the badger not only lapped it up freely, without appearing to be at all the worse for it, but seemed rather to like it than otherwise, and he was obliged to resort to some other less doubtful measures for the poor beast's execution.

A milk-white dog Fox was during last autumn (1859) taken up alive before the Isle of Wight hounds. Although the run had been a good one, and they ran into him in the open, yet, strange to say, when they came up with him, doubtless in consequence of his unusual appearance, not a hound would touch him, and he was taken up out of the midst of them perfectly uninjured. He was conveyed to the stables of the master of the hounds, where, a suitable residence having been organized for him, he still remains in very flou- 
rishing condition. He cannot, of course, be expected to be very tame yet, but the few months during which he has been in captivity have done much towards overcoming his natural timidity, he having already become so far reconciled to the noise and bustle of the stable-yard, as to sit quietly sumning himself on the top of his "earth," whilst the men are engaged in their usual avocations.

It has been suggested that he may owe his colour-or rather, I believe I should strictly say, absence of colour-to the paternity of an Arctic fox, which was some years ago in the possession of a gentleman in the Island, and afterwards made his escape. As, however, this one exhibits none of the peculiarities of form which characterise that species, I am inclined to believe him to be simply an albino.

The fancy which Cattle have for bones appears to me not unworthy of observation. The shootinglodge, which, as I have before mentioned, I occupied during a couple of seasons in Ross-shire, was only separated by the road from a sea-loch, into which were thrown all the refuse bones from the establishment. Here, every day at low water, might be seen the cows of the neighbouring 
farmer, twelve or fourteen in number, (sometimes accompanied by the bull), at first busily engaged in searching for these, and afterwards each occupied for a couple of hours in quietly mumbling her bone. Occasionally one would succeed, after some time, in reducing hers sufficiently to enable her to swallow it, when down it slipped, and she immediately set about looking for another, or, if she could not find one, endeavouring to filch that of a more fortumate neighbour. Bones were evidently the peculiar objects of their search, but, if bones ran short, they would make shift with lobster-shells, or even, as I remember seeing on one occasion, the sole of an old shoe.

These cows had plenty of pasture, and were in good condition. Whether they really relished the bones for their flavour, or were merely actuated by an instinctive impulse, such as induces dogs to eat grass, or birds gravel, for the purpose of aiding digestion, I will not pretend to determine: any way, whatever may have been the inducement, they evidently derived very considerable gratification from the act of mumbling them.

It has been supposed by some people, as a means of accounting for the mysterious disappear- 
ance of the horns annually shed by stags, that they may be eaten by them and the hinds. I was formerly inclined to treat this as a fiction, but seeing the extraordinary avidity with which in this case the bones were sought after and eaten by the cattle, I was led to imagine that there may be some foundation for it. It is indeed difficult to understand how such hard and intractable substances as a Deer's antlers could be thus disposed of, but there is no saying what a patient and persevering mumbling of them day after day might not effect. It is well known, besides, that other animals (Toads and Shrimps for instance) are particularly fond of their own exuvice, and, so far as it goes, this fact might be adduced as an argument in support of the theory.

Of all the stenches which it has been my misfortune to meet with, I know none to be compared in point of offensiveness with that emitted by the Common Snake when irritated, as mentioned before, page 174. But judging from the account given me by a friend, of a Goat in his neighbourhood, I should think that in a match for unsavouriness between the snake and the goat, the latter would probably have come off easily victorious. The intensity of the stink proceeding from 
him is said to have been utterly beyond belief and indescribable: from the following results produced by it I am assured but a faint notion of it can be gained.

One day while my friend was out partridgeshooting, the goat, who was disposed to be disgustingly familiar, came to such close quarters that he gave him a kick, as the quickest means of getting him out of the way. In doing this, his trowsers having happened to come in contact with the brute, they from this slight touch became so contaminated, that, although he did not put them on again until the ensuing spring, he then not only found them to be still unwearable in consequence of the smell, but after divers measures had been taken with a view to their purification, the attempt was relinquished as altogether hopeless, and he had them destroyed. And this odour was not only intolerable to human kind, but the very dogs were made sick by it, a fact to which a brother of my friend, who fell in with the goat another day, while out shooting, bears witness, in answer to a question from me, as follows: — "Touching the goat, I personally saw a dog, a spaniel, give up hunting, 'cling' its tail, and run off towards home, giving every sign of being about 
182 BIRDS FASCINATED BY HUMAN EYe. [PART II.

to vomit. Whether he really did so I did not observe. It was not until we had gone some distance that the dog would do anything (in the way of work) again." I had previously always imagined dogs to be stink-proof. It must indeed have been one of no ordinary intensity which could thus affect them.

The fascination which the human eye exercises upon birds is very remarkable, and is susceptible of the following simple proof, which I found out in my bird-trap-setting days. If you hold a Robin steadily by the upper part of the legs a few inches from your face and look fixedly at him, you will obtain complete possession of his attention, and his eyes will become riveted upon yours. If then, keeping your hand perfectly still, you move your face away from him, he will protrude his head to its utmost stretch; and in a similar manner, on your advancing your head, he will again withdraw his, so as to keep his eyes, as far as possible, at the same distance from yours. It may be as well to be careful as to the choice of the kind of bird upon which such an experiment is tried, as some of the hard-billed birds might be inclined to reverse the order of things, and try their own powers upon your eyes. A Heron, for instance, 
would probably make himself a peculiarly disagreeable subject.

If birds are thus susceptible of the influence of the human eye, may there not possibly be some truth in the popular idea that they are charmed or fascinated by that of the Snake?

Among the uneducated classes in the Isle of Wight, in common probably with those of other districts, the belief that diseases can be "charmed away" still prevails to no inconsiderable extent. Although I believe that other infirmities are at times similarly treated, yet rheumatism and warts seem to be those as to which the remedy is supposed to be peculiarly efficacious.

The "charmers" being naturally anxious to keep their secret, if they have one, and if they have not, to make up for the want of it by an appearance of mystery-while their patients, suspecting that the educated classes look upon the "charm" as a remnant of superstition, and fearing that they may, by avowing their belief in it, expose themselves to ridicule, are somewhat disinclined to talk freely on the subject-there is some difficulty in obtaining information as to the process by which it is supposed to be effected. It appears, however, to consist in uttering certain 
cabalistic words over the patient, counting the warts, when warts are treated for, and placing straws across the part affected, the straws being subsequently deposited in a secret place known only to the charmer. In cases where an arm is affected, a string is also occasionally tied round the wrist.

Whether the effects ascribed to the virtues of the charms are in fact attributable to the indirect influence of the imagination, or otherwise, we need not here inquire; but the fact that the art, if it may be so called, is still practised, is probably a sufficient proof that the results derived from it are occasionally, at any rate, considered satisfactory.

I myself know of one instance, in which the cure was so rapid and perfect, that any doctor might have pointed to it with pride as a convincing proof of the efficacy of his treatment. It was a case of warts; the patient being a little girl of about seven or eight years old, the daughter of a servant in our family. She came up one day to the house for some work, when the lady, who was giving it to her, having remarked that her hands were covered with bad warts, and noticed the fact to her, she said, "Yes, ma'am, but I'm 
going to have them charmed away in a day or two." "Very well," answered the lady, glad to have the opportunity of convincing the child that the whole thing was a delusion, "when they are charmed away, come and shew me your hands." But about six weeks had elapsed after this had taken place, when she was again told that the girl wished to see her. She was accordingly shewn up, when she said, "If you please, ma'am, you told me to come and shew you my hands when the warts were charmed away, and, you see, ma'am, they're all gone now." This, it must be confessed, was rather a "sell" for the lady; however, the fact being undeniable, all she could do under the circumstances was to say that it was a very good thing that she had got rid of them, and that she was very glad of it.

I am told that in Sussex, where "charming" is also much resorted to for the cure of warts, the process of counting them is the part of the charm which is apparently the most relied on.

Domestic animals not unfrequently contract sudden fancies for, and occasionally as sudden aversions to particular individuals, in a strange manner, the latter being apparently more difficult to understand than the former. Doubtless some- 
thing or other has passed through the animals' minds, which, could we know what it was, would fully account for this conduct on their part, while to those unacquainted with the cause, they appear to be actuated solely by caprice. The following instances have happened to occur within my own knowledge:-A brother of mine, when in the army, had a very favourite little Spaniel which was devotedly attached to him, and his constant companion. During a visit of a few days however, which I paid him, when quartered in Cork, and on the eve of embarkation for foreign service, the dog took such an extraordinary fancy to me, that he decidedly preferred my company to that of my brother, and indeed quite deserted him for me. On my leaving to return to England my brother kindly gave him to me, and he as a matter of course followed me on board the steamer, leaving my brother standing on the quay. The steamer sheered off, and proceeded on her course, but no sooner did the dog perceive that he was really to be separated from his old master, than all his former affection for him appeared to return in its full force; in every way in which a dog can express contrition he seemed to do so for his error in having forsaken 
him for me; and I was actually obliged to hold him, in order to prevent him from jumping overboard to rejoin him. I had him (poor Crick !) for some years afterwards, until one unlucky day, when, during my absence from home, he was taken out rabbit-shooting by the servants, and a stray shot ended his existence.

The brother, whom I have just mentioned, had also a tame Squirrel, which he used generally to feed himself, and invariably treated with the greatest kindness. For some time (two or three years I believe) the squirrel was extremely fond of him, as it was of his wife, and would allow them to do anything with it, running all over them, and not exhibiting the slightest symptom of fear or mistrust. Suddenly however, and without any apparent cause, it took the greatest possible aversion to him, flying at him when it was let loose, and biting him in a most savage manner. I have seen his hands streaming with blood from the effect of its bites. For my sister-in-law, on the contrary, it always manifested the greatest affection, and never shewed the slightest alteration in its feeling towards her.

With a Macaw belonging to us I used to be on the best of terms, and he always appeared very 
fond of me, until I was entirely supplanted in his affections by the butler. Even then we were very good friends so long as the butler was not in the room, but the moment he made his appearance, the bird seemed to be seized with a feeling of the greatest possible hostility towards me, attempting to bite me, and shewing his animosity in a most decided manner. On these occasions I generally abstained from putting my fingers too close to him, but once, having on a thick velveteen shooting-coat, besides shirt and flannel-waiscoat, I thought I might venture to test his disposition by offering him my arm in an amicable manner. Had the butler not been there, he would at once have come on it, but, as it was, he soon set all doubt at rest, by taking a piece clean out of coat, shirt, flannel-waistcoat and arm at one fell bite.

A Kitten once attached herself to me in a manner which was certainly very remarkable, particularly as I do not remember ever to have cultivated her affections by any other means than those of simple kindness and attention.

The place where she was supposed to live of a morning was a room appropriated to the lady'smaid, lying beyond a back-staircase, by which I 
was in the habit of ascending to the room where I used to sit. Being very fond of the maid as well as of myself, she used to besport herself or sleep contentedly enough in her room, and evinced no desire to leave it, until she heard my step approaching on my way up-stairs. She was then up and after me in a moment, following me to my room, and taking up her favourite position on my table, where she used to sit, if I would allow it, with her paw over my hand whilst I was writing, a proceeding of which many a blot was the consequence.

From the position of the lady's-maid's room, it was impossible for the kitten to have seen who was approaching the staircase, but her sense of hearing was so acute, that, though many other persons ascended it in the course of the morning, she (as I was assured, and have no reason to disbelieve) never attempted to move at the approach of any other step than my own.

The bond of friendship which thus existed between us was however condemned to be broken. I was absent from home for a good while, during which the kitten, having attained to the age of cat-hood, retired from the upper part of the house, where we should perhaps have revived our in- 
timacy, to the lower regions, and in due course of time subsided into a vulgar good-tempered kitchen cat, in which capacity I believe she still survives.

Having alluded to my little dog "Crick," I cannot refrain, before taking leave of him here, from mentioning the original method in which he used to resent the impertinences of a small cur, which was continually insulting his dignity by running up and barking at him. When this happened Crick used to "go in" at the offender, as if determined to chastise him, which he would perhaps have done, had not the other at once cried "peccuvi," and deprecated his wrath by lying down crouching on his back. I have heard of a big dog under similar circumstances taking up the small one, and dropping him into a dirty puddle; but Crick, instead of total immersion, adopted another kind of baptism, the appliances for which were always at hand, and which certainly served in a most unmistakable way to express his utter contempt for his tormentor; walking off after it, back up and muscles all rigid, without deigning another glance at his prostrate victim. I have seen this happen over and over again. 
CH. III.] ODD PECULIARITIES OF SPANIEL.

Two other of his peculiarities may perhaps be also worth recording. One of these was his extreme sensitiveness in point of "ear" for music. If he were lying fast asleep in the drawing-room, and two or three discords were (purposely) struck on the piano, he would instantly jump up, and express his horror of them by a dismal whine. The other was his dislike to have anything floating about in his "tea." I have seen him start back and growl at a tea-twig (in nursery parlance "stranger") which happened to come to the surface whilst he was drinking it. 


\section{CHAPTER IV.}

Buzzards-pair of-anecdote as to-Return of Migratory Birds to same haunts-Same harbour holds Trout of same size-Starlings-breeding of in the Isle of Wightlarge flock of-Visitation of Buntings-Increase of Wood

Pigeons-Their numbers fuctuate_Stock Dove.

FINE Buzzard was towards the end of De-
cember 1856, shot by the tenant on a farm situated on the north side of the Island. There was another in company with it, which he said he could also have killed had he had a double gun with him instead of a single. About a fortnight after this happened, whilst a party were shooting about a couple of miles from the place, one of the beaters picked up another buzzard just dead, and still warm, but exhibiting no apparent cause for its death. It had not been shot at by any of the party. On examining it, I found that one of its feet was contracted, to such an extent that it could not be opened, and was consequently led to suppose that this might have 
been the bird seen in company with the other, to which it might, being disabled from catering for itself, have been indebted for its means of sustenance. If such had been the case, it would probably in about that time after the death of its companion have pined away and died from want. It was very poor, though perhaps not quite such a skeleton as might have been expected if its death had resulted simply from starvation.

There used to be a good many Buzzards in that part of the country until within the last forty or fifty years. An old gamekeeper on the property where the two last mentioned were found, on whose word I could most thoroughly depend, has told me that a pair used to build every year in a particular tree in a covert three or four miles from the farm last mentioned, and that, as regularly, he used to destroy at least one, if not both of the old birds. He assured me, however, that the fact of his having killed both the old birds made not the slightest difference, and that the following year another pair invariably built or reconstructed their nest in the same tree. This, he told me, went on for a good many years, until the tree in which the birds had been accustomed to build was cut down, when, with it, the attraction 
194 RETURN OF BIRDS TO SAME HAUNTS. [PART II.

which had brought them into the neighbourhood apparently ceased to exist, for from that time he had never seen a single individual of the species. Those which I have mentioned as making their appearance in 1856 are the only specimens that I remember ever to have heard of in the Island since he told me this some fifteen or eighteen years ago.

The instinct which led the Buzzards (in the instance I have mentioned) to seek out a particular tree as peculiarly apt for the purposes of building, is certainly very remarkable, but it is perhaps scarcely more so than that which induces somemost indeed, I believe I may say-of our migratory birds to return to (or rather haunt) the same localities year after year in almost precisely the same numbers. I may instance Woodcocks, and shall, I am sure, be borne out in my assertion by the experience of all sportsmen who have opportunities for forming an opinion, when I say that not only the same coverts, but the same parts of those coverts, will almost invariably be found at the same season to produce very nearly the same number, it being perfectly immaterial whether the whole of the contingent furnished by it the preceding year had been killed off or not. 
But one pair of Peregrine Falcons has, it is said (and, so far as I am able to make out, correctly), ever been known to breed at one time in the cliffs at Freshwater. Every year the nest is robbed by the fishermen, who get good prices for both eggs and young birds, and none of the latter are therefore ever suffered to escape. Frequently one of the old birds has been shot, and occasionally both have shared the same fate while engaged in nesting there, but none of these circumstances has ever made the slightest difference, and the due appearance of a pair at the breeding season has never been interrupted.

The mysterious way in which Trout appear to become acquainted with the fact that a vacancy has occurred behind a particular stone, or other favourite harbour, has, I dare say, struck other fishermen besides myself, who will doubtless have noticed how invariably such a locality is the haunt of a "good fish," the tenant in occupation being very frequently about the same size as his predecessor.

Formerly such a thing as a Starling's nest was (I believe) unknown in the Isle of Wight. Now they breed there in great numbers, scarcely a convenient hole in tree or thatch being without 
196 STARLINGS BREEDING-VAST FLOCK OF. [PART II.

its nest. The first instance in which I ever heard of their doing so was between thirty and forty years ago, when the coachman of the late Sir John Barrington, having brought with him from Essex a nest of young Starlings as a curiosity, was told that a nest had just been discovered near Newchurch. They have ever since remained to breed in the Island in gradually increasing numbers, but it is only within the last fifteen or twenty years that they have done so nearly to such an extent as at present.

I saw on the 18th of November, 1852, in the Island, a flock of Starlings far exceeding in numbers any that had ever before come under my own observation, or that of any of the party who were with me. It would be impossible to form an estimate of their numbers, but they blackened a very large extent (several acres I should think) of the field on which they had alighted. One of our party fired at them at an enormous distance, and knocked down about sixteen, a number which he would probably have more than doubled, but that he, not seeing the main body, fired his first barrel at a small detachment. It seemed to be their first and only appearance, for I could never hear that this vast flock was ever seen again. 
On my return from abroad (I think in the year 1845), I found that the western part of the Island had been visited, about the month of March, during a cold backward spring, by multitudes of a small bird, which were described as about the size of, and scarcely distinguishable from, Titlarks, and to which the labourers gave the odd name of "Norway Widgeons," why I never could understand, nor they explain. They were subsequently found dead in great numbers along the shore on the south side of the Island, from which circumstance it would appear that they were immigrants, who had come to us in transitu, and failed in their attempt to proceed further. During their temporary residence in the Island they caused great havoc among the young green crops. I endeavoured, but without success, to obtain a specimen of them, and was therefore unable to ascertain the species with any certainty. A friend of mine, who saw them, imagines that they were Titlarks. I am myself rather inclined to fancy they must have been Buntings.

The number of Woodpigeons has of late years decidedly increased very largely in the Island; nor is this increase, I believe, confined to that locality, as $I$ have repeatedly heard the same fact noticed 
in other parts of England. That this should be the case is certainly not a little extraordinary, for, considering that the number of eggs in each nest is limited to two, and that these, from their colour, from the loose fabric of the nest, and the comparatively slight attempt to conceal it by the parent birds, are perhaps more easily discoverable by their biped enemies, winged and human, than those of any other bird; that the Woodpigeon itself is, from its fondness for ripe corn and green crops (particularly turnips) very obnoxious to the farmer, at whose hands it consequently meets with but little mercy; and finally that it is universally appreciated for the table; one might naturally at first sight suppose that there was no bird a gradual decrease in whose numbers might be predicted with greater confidence.

In the Isle of Wight (and perhaps the same observation may apply to other parts of the country as well) I believe this singular increase in the number of Woodpigeons is mainly owing to the increase which has taken place of late years in the cultivation of the turnip-crop, the leaf of that plant during the winter, and indeed as long after it as any remain in the ground, constituting by far the principal part of their food. Although they 
are blamed for attacking the root as well as the leaf, yet they are guiltless of the charge. Their bills would not be strong enough to enable them to commence operations on one, even if so disposed, and the utmost harm they could do it, would be to pick off a loose piece, when the root had been previously scarified. At any rate, I have never seen a particle of the root in their crops, which are often distended with the leaf to such an extent that the protuberance caused by it shews conspicuously even at a distance when they are on the wing. The Rooks are the real culprits who have to answer for the deep holes bored in the roots, a fact of which any one may satisfy himself, by at any time during the winter examining the ground under the trees in which they roost at night.

But to return from this apologetic digression. That the Woodpigeon is to some extent migratory, cannot, I think, be doubted. My impression with regard to this increase in their numbers is therefore, generally, that whereas formerly only so many of those, who came as occasional visitors to the Island, remained there, as found they could readily obtain food, the rest migrating elsewhere when it became scarce; of late years, since the 
increase in the cultivation of the turnip-crop, the immigrants, finding that there was an ample supply of food for them, as well as the native birds, and finding the place suit them in other respects (as, for instance, affording plenty of covert, and that, or at least a large proportion of it, but little disturbed), were induced to prolong their stay throughout the winter, and thus became naturalized there.

Their numbers still occasionally vary. During the years 1849 and 1850 I noticed that they appeared to be not nearly so numerous as during some preceding and the subsequent years. Why this should have been the case I do not know, for there was no perceptible diminution in the usual turnip-crop, nor apparently any other reason by which it could be accounted for.

Still, each year, about the end of October or the commencement of November, a large proportion of the Woodpigeons appear to leave the island, returning again in about two months to their old haunts. During this period they are, I have but little doubt, absent on an excursion to the New Forest in search of beech-mast, perhaps their most favourite food, which is supplied there in greater quantities than the Island affords, and 
whither these birds resort, I am told, in great numbers at that season.

The Stock Dove is surprisingly rare in the Isle of Wight, considering how widely the range of that bird extends, and the fact that it is not unfrequently met with along the western part of the coast of Hampshire. I believe I have never myself seen one of these birds or heard its note in the Island, nor have I ever heard of any being seen there, except on two occasions, these occurring as far back as about thirty-six and eighteen years ago respectively, and both in the neighbourhood of Brixton. They were described to me by two intelligent men, who saw them, as coming in great numbers "like a cloud of Rooks" from a northeasterly direction, pitching "under the down," and feeding onwards, without altering their course, the hindmost birds flying over the heads of the advanced column, and feeding in front, until they were, in their turn, similarly passed by the rearguard, as Starlings may be observed sometimes to do. This desultory mode of settling is by the way, I apprehend, exactly what Homer meant by the

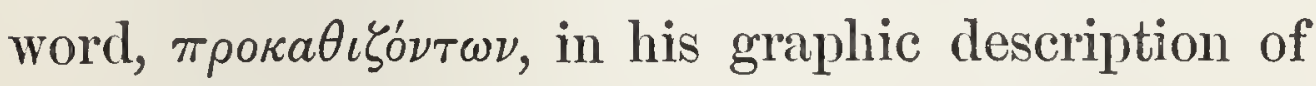
waterfowl, $I l$. B. 459-463. I have, of course, no positive proof that the birds of which these flocks 
were composed were of the Stock Dove species (Columba oenas), but conclude that such was the case from the description given me of some which were killed. 


\section{CHAPTER V.}

Rarer Birds visitors to the Isle of Wight-Spoon-bill-Rednecked Phalarope - Bittern-Gannet-White-fronted (Laughing) Goose-Black Redstart-Common DittoHoopoe-Snow Bunting-Cirl Bunting-BramblingMerlin-Hobby - Grossbeak-Wryneck-Grasshopper Warbler-Stone Curlew-Dotterel-Ring Dotterel and Ox-bird-Grey Plover-Golden Plover-Protest against lilling rare Birds.

MONG the rarer birds which have come within my own knowledge as visitors to the Isle of Wight are the following:-

The Spoonbill. The Red-necked Phalarope (Phalaropus hyperboreus). The Bittern (at least two instances). The Gannet; - one of these birds was in December, 1853, after a storm of unusual violence, found by some boys going to plough at a distance of several miles from the sea: it was unable to fly more than a short distance, and they soon ran it down, when they "disarmed the terrors of its beak" by running a knife into its throat. Another of these birds had been, singu- 
204 RARER BIRDS IN ISLE OF WIGHT. [PART II.

larly enough, found under similar circumstances only about three weeks before, within a mile of the same place. The White-fronted or Laughing Goose (Anser albifrons). The Black Redstart (Phonicura tithys), (two shot the same day, about 1850, in the neighbourhood of the Undercliff): of its cogener, the common Redstart, though so much more common in some localities than the black variety, I believe I have never known above a single specimen obtained in the Island. The Hoopoe (several instances). The Snow Bunting (Plectrophanes nivalis). The Cirl Bunting (Emberiza cirlus); - I saw two of these birds feeding together on the gravel-walk close to a house near East Cowes, in February, 1858, and having watched them for some time through a good glass, am able to speak positively as to their identity. The Brambling (Fringilla montifringilla) I have also seen on more than one occasion. Though I do not remember to have heard of the Merlin for some time past, yet until within the last few years it was by no means an unfrequent occurrence for one to pay the penalty to which his predatory habits rendered him liable, I having been myself on several occasions his executioner. The Hobby appears to be much more rare in the Island than 
the Merlin, though the converse is, I believe, the case throughout the southern parts of Hampshire and Dorsetshire. I can call to mind indeed but a single instance of its being met with there.

The Grossbeak (Loxia coccothraustes) was, some twenty or twenty-five years ago, very common during one or two winters, when my brothers and I (as boys) used to shoot so many in common with Blackbirds and Thrushes, that we scarcely thought more of them than of those birds, and many were the pies and rotics to which they contributed in no mean proportion. Since that time, however, they have become comparatively scarce, and two, or perhaps three, stragglers is the most that I remember to have seen. The last was in January or February 1858. The Wryneck (Yunx torquilla-Vecticè "Barley-bird") used to be one of our most regular visitors, but has gradually become more and more rare, and we are now scarcely ever greeted by his lively call. The Grasshopper-warbler (Salicaria locustella) is not common, and appears to confine himself exclusively to particular spots. I know of only one covert (of about four acres) in which he is to be heard, but this apparently never fails to contain one or two during the summer. Till within the 
last twenty years, the Stone Curlew, a bird of many aliases, but recognisable as Bewick's Charadrius octicnemus, never failed to visit us during the summer, confining himself principally to the higher ground, where the plough had crept in upon the central ridge of down which bisects the Island. In common, however, with several other species, this bird has almost ceased to visit us, and until the year 1857, when three or four were seen and two killed, several years had elapsed since I had heard of the appearance of one. It is long since I myself have heard their wild whistle in the uplands. Of the Dotterel (Charadrius morinellus) I have, to the best of my belief, never met with above a single specimen in the Island. The Ring Dotterel (Charadrius hiaticulaVecticè "Bull-bird") occurs in considerable numbers, consorting with its friend the "Ox-bird" (Tringa variabilis) along the muddy flats and harbours on the western part of the north coast. I believe I may also undertake to say positively that I have in the same locality killed, when a boy, several specimens of the Grey Plover (Squaterola cinerea, Yarrell). I then imagined them to have been Golden Plover (Charadrius pluvialis), but have since been satisfied that I was mistaken. I 
have, however, seen the Golden Plover on the higher ground in the island, and known of several instances where it has been shot.

There appears to exist too often an insane desire to kill rare birds, for no other reason than because they are rare, not with a view to add to the stock of knowledge already possessed with regard to the birds, but from a morbid wish to gratify the vanity of the person who kills them. This surely cannot be too much deprecated, for, should the practice continue unchecked, in proportion as each species gives way before the increase of population, exactly in the same proportion will the gun be raised against it, and thus the present generation may live to lament the absence of many familiar winged friends by which their eyes and ears are now gladdened.

A picture appeared in Punch, a year or two ago, representing two men of the "navvy" class, watching a traveiler quietly passing along the road near them, one of whom says, "I say, Bill, yon's a stranger." Upon which his friend answers, "Oh, is a ? 'eave 'alf a brick at 'en then." Now this, which is intended as a hit at the brutality and inhospitality of some of our uneducated classes (scarcely merited, I hope and believe), may, 
it strikes me, be deservedly applied to many of our soi-disant naturalists, looking to their reception and treatment of any bird whose misfortune it may be to be considered rare, and which may be compelled by stress of weather, or induced by other causes in misplaced confidence to visit our shores. The intelligence that such an unhappy immigrant has appeared is generally the signal for every one who pretends to the slightest knowledge of ornithology to turn out gun in hand bent on its destruction, the excitement of pursuit being probably only allayed by an announcement in the county paper headed, "Rare Bird," a too familiar type of which is as follows :"On Saturday last that enthusiastic and accomplished ornithologist, Mr Snooks, was so fortunate as to obtain two specimens, male and female, of that rare bird the Peregrinus fidens. They had been for some time observed in the neighbourhood, and many of our naturalists had been eagerly on the watch to secure them. We heartily congratulate our esteemed fellow-townsman on the attainment of this trophy, which will serve to add new lustre to his already celebrated name. From the fact that the female bird had a feather in her bill, when she was shot, there can be no doubt 
that these interesting visitors were in the act of constructing a nest when they fell before $\mathrm{Mr}$ Snooks's unerring tube."

It was not very long ago that I saw in The Times a letter from a "naturalist," relating how a Harlequin-duck had visited his pond, and become quite domesticated there, swimming about with his other ducks, and coming tamely to be fed with them day after day. Of course this could not be permitted: the poor Harlequin-duck was much too rare to be allowed the common rites of hospitality, so he was "secured," and the perpetrator of the deed, apparently thinking he had done a fine thing, actually wrote to The Times, informing the civilised people of England of his achievement, and evidently expecting to be belauded on the strength of it. Another so-called "naturalist" similarly boasted through the medium of a newspaper, that he had been so fortunate as to "secure" (that seems the correct term) a Nightingale, in the West of Devonshire, having shot it whilst in the act of singing on the topmost branch of a thorn-bush. Another instance of the same kind has come within my own knowledge, where a person having been unsuccessful in his attempts to approach a Stone Curlew, whose nest 
he had found, laid wait in ambush, and "secured" the mother-bird, by shooting her as she ran up to it.

Now it is no doubt very interesting to know that a Harlequin-duck has visited such or such a locality, and still more so that it has been so far reconciled to the presence of man, as to become, to a certain extent, domesticated; but could not these facts be established without the sacrifice of the poor lone wanderer? Again, from the remarkable fact that Nightingales are very rarely found west of particular boundaries, it is certainly a note-worthy incident when one has deviated from the law which seems to keep them to the east of those limits; but surely the last-mentioned "naturalist" might have been satisfied with his own evidence or that of his friends, in proof of the poor bird's visit, without killing it. How can the Devonshire people expect to have their ears gladdened with the bird's sweet song, if that is the way they welcome the casual visitors of the species? Of birds which formerly were comparatively abundant in the British Islands, one or two species may be said to have disappeared from amongst us, whilst of others not a few now make their appearance only at distant and uncertain intervals, too 
many of them, alas! never to return to the country which afforded them the shelter they have been here denied. Were such occasional visitors protected, instead of being hunted to the death, as they are at present, it is not only possible, but, I think, probable, that some at least might be induced to remain permanently with us, and thus become naturalised in our Islands, while others, of the purely migratory class, might return periodically to our shores in increasing numbers. I would not go the length of saying that an exceptional case may not now and then occur, when the ends of science may be advanced by the acquisition of an individual of rare or doubtful species, but I should indeed be glad if my humble voice could be echoed by a general protest against the indiscriminate destruction of birds merely because they are rare. 


\section{CHAPTER VI.}

Tameness of Animals on Sundays-Anecdotes as to HorsesSpaniel-Pomeranian Dog-Note of Peewit-Grass scarified by Rooks-Bareness at base of Rook's billInfants - Young Asses - Young Elephants - Lofty flight of Moorkens at night-Land-rail-Quail-Woodcockcarries young from place to place-Snipe-SquirrelsNuts and Nutshells on Down-Star on Hare's foreheadSparrows congregating in hard weather.

THE tameness of animals on Sundays, in coun1 tries where the day is strictly observed, as contrasted with their comparative wildness on other days, is, I think, so remarkable as scarcely to admit of a doubt. As it can scarcely be imagined that their instinct can lead them to mark the regular recurrence of the day, and their immunity during it from pursuit and danger, it must probably be accounted for by the fact that, labour being suspended, a general stillness pervades the country, insensibly conveying to their minds a sense of security. Domestic animals, however-and those particularly which are most 
CH. V1.] TAMENESS OF ANIMALS ON SUNDAYS.

closely associated with us, and as it were form part of our families-become, I am persuaded, perfectly aware of the regular advent of Sunday, and not unfrequently shew that this is the case, by voluntarily adapting themselves to the requirements of the day. There would probably be no difficulty in collecting a sufficiency of instances in support of this theory to establish it, but I will just mention the two following which happen to occur to me. The Carriage-horses of a friend of mine were accustomed on week-days to take their mistress out for an early drive before luncheon, while on the Sunday they enjoyed a perfect rest. On the week-days they never thought of lying down in the morning before the time when they usually went out, but on the Sunday mornings they invariably did so, as if determined to make the most of their day's rest. I supposed that they might have been induced to do this in consequence of their beds being made up earlier on those days, or of some other departure from the usual routine of the stable arrangements, but I was told that no variation of the kind was ever made.

A King Charles' Spaniel belonging to a lady, a relation of my own, was constantly in the habit of attending her when she went out driving, and, 
if it was wished that he should not accompany her, it was necessary to shut him up to prevent him from doing so. On Sundays she went to teach at the village-school, where his presence was of course undesirable. To my surprise one Sunday morning I saw her preparing for a start to the school, leaving "Beau" at liberty in the diningroom, which was on the ground-floor, opening on the carriage-drive by which she would leave the house. I was proceeding to shut him up, when she said, "Oh you need not trouble yourself to do that; he knows quite well that it is Sunday, and won't attempt to go with me." She was perfectly right. Beau sat in a chair, watching her through the open window as she drove off, looking the picture of mortified resignation, but not offering to quit his place, though he had not been told to remain there.

A more remarkable story has been handed down from the last generation in our family, which, although I camnot vouch for its authenticity, I fully believe. In this instance, it was a favourite Pomeranian Dog, who having been several times prevented from following the family to church, a distance of about a mile and a half from the house, used to start some time before them, 
and, getting into their pew, remain perdu there until they came, when it was thought better to allow him to remain quietly where he was, than make a disturbance by turning him out.

It was remarked to me by a farmer one day, when, whilst out with the hounds, we came across a flock of Peewits, "It's a bad sign to see they birds"-explaining his meaning to be that they generally haunt only poor, bad land, in which he was certainly correct.

In the Isle of Wight (and indeed I believe generally in the South of England) these birds are invariably called by the lower orders not "Peewits" but "Pewits," and I am inclined to think that they are right; for, although the bird does vary its note, and at times, particularly when pursuing a straight course in company with others, occasionally gives utterance to a note resembling "pee-wit," yet I am mistaken, if, generally, when circling round an intruder (at which times its cry is louder and more marked than at others) the cry does not more nearly approach to "pew-it," greater stress being laid on the lower note in the early part of the cry than on the higher one which concludes it.

I was walking one day with a gentleman over his home-farm, when we observed the grass on 
about an acre of meadow-land to be so completely rooted up and scarified, that he took it for granted it had been done under the bailiff's direction to clear it from moss, and on arriving at the farm inquired whether such was not the case. The answer, however, was "Oh, no, Sir, we haven't been at work there at all; it's the Rooks done all that." The mistake was a very natural one, for though I have often seen places where grass has been pulled up by rooks, yet I never saw such clean or wholesale work done by them as on this occasion. It could not apparently have been executed more systematically or perfectly by the most elaborate "scarifier" that Crosskill or Ransome could turn out. On examining the spot afterwards I found that the object of the rooks' researches had doubtless been a small white grub, numbers of which still remained in the ground a short distance below the surface. In the following spring I noticed that the part of the field where this had taken place was densely covered with cowslips, much more so than the rest of it. Possibly the roots of these plants may have been the proper food for the grubs, and therefore selected by the parent insect as receptacles for her eggs.

A sharpish controversy has been maintained 
amongst naturalists, as to whether the bareness of the Rook's bill is, as Bewick says, "an original peculiarity," or whether the feathers which at first grow on its base are worn off by contact with the soil into which it is constantly thrust. It seems to me that those who hold the former theory have the best of the argument, but as the only way of proving which is in the right would be to confine rooks from their infancy in a place where they could not possibly have access to mould, or other substance by which the bill-feathers could be rubbed off, it will probably be some time before the question is solved. Yarrell mentions that "two or three other birds (not British) are now known to exhibit this peculiarity of losing the bill-feathers," but we might go nearer home for a case, in which something analogous occurs, that of babies, on whose foreheads at their birth is visible a distinct down, which shortly afterwards disappears. Nor is this peculiarity noticeable only in babies: every one must have observed how much more woolly the heads of young asses are than those of older ones, and Sir J. Emerson Tennent in his interesting Work on Ceylon (Vol. II. p. 385, note) similarly remarks that, "the young elephants, when captured, are frequently covered with a 
218 FLIGHT OF MOORHENS AT Night. [PART II. woolly fleece, especially about the head and shoulders."

Others, besides myself, have probably noticed how suddenly and mysteriously Moorhens will sometimes disappear from a piece of water, especially if they have been disturbed by the cutting of the wood on its banks or other causes. There can be no difficulty in accounting for this, if, as I am persuaded, they occasionally take at night much more extensive flights than their general habits would lead one to suppose probable. Unless there is any other bird, of which I am ignorant, whose cry precisely resembles that of the Moorhen, I am positive that I have several times heard them on wing at night high overhead, three of the occasions being very remarkable, namely, while they were passing over Christ Church (Oxford), Lincoln's Inn Fields, and Blackfriars Bridge. of course it is possible that I may have been mistaken, but I am so intimately acquainted with the cry of the bird that it would be very difficult to satisfy me that such was the case.

That they may have the power of taking such extensive flights may, I think, be easily conceded, when it is remembered that the Landrail, whose power of wing scarcely, if at all, exceeds that of 
the Moorhen, cannot reach these shores without crossing, at least, some twenty miles of water.

I have heard similar strange stories of the disappearance of Dabchicks (Podiceps minor) from inland ponds, taking with them their young which had only been hatched a few days.

The Landrail is tolerably abundant in the Isle of Wight, where I have indeed two or three times heard of their being met with in considerable numbers. A gentleman of my acquaintance assures me that in the year 1853 he, with the assistance of another gun, killed in one day, near Shanklin, nineteen and a half brace before luncheon, and another day twelve brace; and again, last year, 1858, a relation of my own killed eight and a half brace in one field. These large bags were of course made early in the season, it being a rare circumstance, as elsewhere, for even a solitary straggler to be fallen in with after the cold weather has set in. On the 2nd of January, however (I think in 1848), I shot, out of a thick stubble, one of these birds in perfect condition and plumage.

Quails are very scarce with us, and are becoming increasingly so. A bery is occasionally heard of, but that is all. 
220 WOODCOCK BREEDING-CARRYING YOUNG. [PART II.

The Island, in proportion to its size, affords probably more than its share of Woodcocks. Although comparatively few of them remain to breed there, yet such an occurrence is by no means uncommon. Indeed, I have scarcely ever known a summer pass by, without hearing of one or more of their nests. In April, 1834, a woodcock rose before a keeper of ours in such a way that he thought she was crippled, and consequently shot her. He however found, too late, that this imperfect flight was assumed for the purpose of diverting his attention from her young ones, of which he discovered four by their "peeping," and brought them up to the house. They might then have been about a fortnight old. We tried to rear them, and, from the readiness with which they fed on worms, \&c. thought we might have succeeded. However, they unfortunately died one after the other, the last survivor only living about a fortnight. The fact of the Woodcock conveying its young from place to place in its claws seems to be now undoubtedly established. I know of two instances where this has been seen to occur. One of the persons who witnessed it is a keeper who told me he was close to the bird, and could not possibly have been mistaken. 
I believe I have never heard of Snipes breeding in the Island, but I shot one, I am ashamed to say, some years ago, on the 24th of April, when he ought to have been thinking about a nest. I could, however, find no trace of one where he rose. They have never been very abundant with us, and, having been of late years gradually "dried out" by (as a sportsman would say) the fatal inroads of drainage, from many places which formerly held them, there are now comparatively few to be met with, and those generally only within circumscribed limits, and under favourable circumstances.

Squirrels, which are now tolerably abundant in the quiet woodlands of the Isle of Wight, were, it is believed, first introduced there by the late Sir John Barrington, about fifty or sixty years ago. The act caused great excitement at the time, it being reported that Sir John "had been and brought in foxes," then proscribed animals. Foxes however were actually introduced about fifteen years ago, and a well ordered pack of hounds, affording excellent sport, is the consequence.

I am afraid Squirrels are mischievous little fellows, and as bad gamekeepers as they are gardeners, having, I fancy, a partiality for eggs as well as fruit. However, I would willingly remain 
blind to these failings, and great must be the provocation which would induce me to lift my hand against them.

One, a year or two ago, happening to find a hole just large enough to admit him in the window of our apple-loft, and probably smelling apples, managed by the help of a convenient vine to effect an entrance, and constantly repeating his visits, used to bring out apples, pears, or anything else which he happened to fancy there, and which he could squeeze through the aperture, until his depredations became so extensive that the gardener thought it was time to interfere, and called in the aid of the glazier.

Great quantities of nut-shells, which have been opened and emptied of their contents (evidently by Mice) are to be found scattered over the face of a down, nearly surrounded by coverts, in our neighbourhood, many at a distance of perhaps a hundred and fifty or two hundred yards from the nearest covert; the greater proportion appearing to be left, I think, in the vicinity of rabbit-holes, but where I looked in vain for any signs of a colony of mice. Late in the autumn many full and good nuts may be found similarly scattered over the down, as if they had been brought 
thither and forgotten, or left for a future time. I am a loss to conceive the inducement which leads the mice to bring them so far from the coverts, to a place where they have apparently no regular harbour, instead of eating them quietly in the shelter of the covert where they find them.

There is a popular notion, which I believe is rather general, that the white star which is sometimes seen in the Hare's forehead is a sign that there were more than one in the litter. It is not likely that any such distinction should exist, but a keeper told me, in proof of the theory, that he had once found a litter of four, just laid down, all of which were thus marked.

It is curious to observe how the approach of hard weather is heralded by the flocking together of House Sparrows in rick-yards. This was very noticeable in the spring of 1853 , when, after the severe frost and snow of the winter had passed away, and given place to more genial weather, scarcely a sparrow was to be seen in the homesteads. Suddenly however they were again filled with large flocks of them, and within two days after, on the 19th of March, came a biting easterly wind and heavy fall of snow, accompanied by a frost of from $4^{\circ}$ to $6^{\circ}$, which lasted several days. 


\section{CHAPTER VII.}

Singular effect of Storm-Great discharge of Sap from Trees-Growth of Ceder of Lebanon-of other TreesChanges in Pond-uceds-Soil collected at mouths of Worm-holes-Maggots from Sea-weed-Disease among Partridges-Boy and Wasps-Midges-Birds on Scotch Sec-lochs-Herons in Loch Duich-Mortality among Seabirds-Skeletons of Weasels in Ricks--Rats.

QN the 10th of August, 1852, a tremendous storm of wind from the south-west, accompanied by rain, swept over the whole of the south coast of England, and in the Isle of Wight entirely killed the leaf wherever it was exposed to its fury. It soon however became manifest that the sap was inclined to reassert its creative power, and in due time afterwards, wherever the old leaf had been destroyed, its place was taken by a new one. The foliage of the trees until quite late in the autumn displayed in consequence a very remarkable contrast, that facing the south-west exhibiting the light green leaf of the second 
growth in all its freshmess, while that on the opposite side, having been smitten, though not killed, by the storm, was completely seared and brown. This reaction was not confined to the forest-trees, those of smaller growth, such as the lilac and laburnum, having also taken a new lease of life, and reappeared in bloom towards the end of September and the beginning of October.

The discharge of sap resulting from the severance of roots or branches of trees is sometimes so extraordinary as almost to exceed belief. Some notion of the quantity which thus escapes may however be gathered from the two following rather remarkable instances:-

I had noticed that a part of a friend's lawn, to the extent of about two feet in diameter had become suddenly converted into a regular quagmire, so saturated with moisture, that, on a stick being thrust into it and withdrawn, the hole thus made was instantly filled with liquid, such liquid being dark in colour and offensive in smell.

The conclusion naturally drawn from these circumstances was that some old and forgotten drain (probably leading from the stables, which were at no great distance) had become choked, and broken up there; and accordingly my friend, 
who had an orthodox horror of "defective drainage," at once had an opening made in the spot, with a view of ascertaining the cause and remedying the evil. On this being done however, it was discovered that the quagmire had been caused simply and exclusively by the oozings from a single elm-root, a part of which had been cut off in consequence of its projecting from the ground, and thus interfering with the operations of the men engaged in mowing the turf. The colour and smell of the sap must, I imagine, be attributable to its having become decomposed after it had left the root.

On another occasion I saw perfect puddles formed by the constant dripping of sap from two or three broken twigs of a young and vigorous walnut-tree; and that too in freshly dug mould, where the soil was naturally rather dry than otherwise.

The growth of the Cedar of Lebanon, so far from being slow as might naturally be expected from its general appearance, and the close texture of its wood, is in fact much more rapid than that of many of our other forest-trees. There is one standing in the Isle of Wight, the girth of which, at one foot from the ground-the spring 
CH. VII.] GROWTH OF OTHER TREES.

of the branches prevents a fair measurement from being taken higher up-was on the 4th of February, 1852, fourteen feet three inches, and on the 17th of February, 1857, fifteen feet one inch. This tree two old men about the place assured me they remembered when recently planted, and tied to a stick for support, their evidence being given quite independently of each other, and the only discrepancy between them being as to the colour of the stick, one saying it was green, and the other blue. They are now dead, but their ages, if still living, would have been about eighty-five and ninety-seven-the elder of the two not having come to reside in the neighbourhood until he was twenty-one. I think then from these data we may safely draw the conclusion that the tree in question cannot be much above eighty years old. According to its present rate of growth, it would be about ninety, but as it probably grew more rapidly when younger, this calculation would seem to point as nearly as possible to the same result. In the size of some large Scotch firs which are standing near this Cedar, these men told me they could detect no difference.

The comparative rate of growth of some other trees, which I measured at the same time, may 
possibly not be uninteresting to some of my readers as gathered from the annexed table.

\begin{tabular}{|c|c|c|c|c|}
\hline & 'TREE. & $\begin{array}{c}\text { Feet } \\
\text { from } \\
\text { the } \\
\text { ground. }\end{array}$ & $\begin{array}{l}\text { GIRTH, } \\
\text { Feb. 4, } 1852 .\end{array}$ & $\begin{array}{c}\text { GIRTH, } \\
\text { Feb. 17, 1857. }\end{array}$ \\
\hline I & Deciduous Cypress & 4 & $\begin{array}{rl}\text { ft. in. } \\
4 & 8 \frac{3}{4}\end{array}$ & $\begin{array}{rl}\text { ft. } & \text { in. } \\
4 & 1 O^{\frac{1}{2}}\end{array}$ \\
\hline 2 & Cedar of Lebanon........... & 4 & 63 & 70 \\
\hline 3 & Weeping Ash ........... & 4 & $4 \mathrm{IO}_{\frac{1}{2}}$ & 50 \\
\hline 4 & Ditto & 4 & $36 \frac{1}{2}$ & $37 \frac{1}{2}$ \\
\hline 5 & Scotch Fir ............. & 4 & Io 3 & $10 \quad 3 \frac{1}{2}$ \\
\hline 6 & Evergreen Oak............ & 4 & $86 \frac{1}{2}$ & $8 \quad 7 \frac{3}{4}$ \\
\hline 7 & Silver Fir .................. & 4 & 93 & $9 \quad 3^{\frac{1}{2}}$ \\
\hline 8 & Ditto $\ldots \ldots \ldots \ldots \ldots$ & 4 & IO $\quad$ I $\frac{1}{2}$ & I0 $4 \frac{1}{2}$ \\
\hline 9 & Red or Virginian Cedar ... & $\mathrm{I} \frac{1}{2}$ & 63 & 6 \\
\hline 10 & Oriental Plane ................. & 4 & I0 $7 \frac{1}{2}$ & 10 8 \\
\hline & 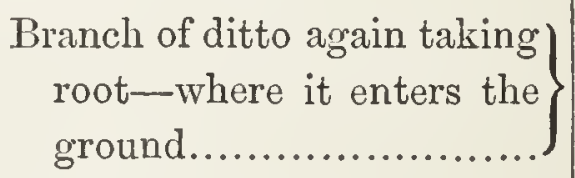 & $\cdots$ & ० I0 & ० 9 \\
\hline & -where it leaves it ............ & $\cdots$ & $2 \quad I \frac{1}{2}$ & $2 \quad 2 \frac{1}{2}$ \\
\hline I I & Cedar of Lebanon........... & 4 & 6 ro & $7 \quad 3^{\frac{3}{4}}$ \\
\hline 12 & Evergreen Oak........ & 4 & 57 & $5 \quad 7 \frac{1}{2}$ \\
\hline I3 & Oak ................. & 4 & 38 & 3 II $\frac{1}{2}$ \\
\hline 14 & Copper Beech ............. & $\mathrm{I} \frac{1}{2}$ & 39 & 47 \\
\hline I 5 & Pinaster................... & 4 & 84 & $8 \quad 4^{\frac{1}{2}}$ \\
\hline I6 & Weeping Willow ........ & 4 & 76 & 7 II \\
\hline I 7 & Yew $\quad \ldots . . . . . . . . . . . . . .$. & $3 \frac{1}{2}$ & $48 \frac{1}{2}$ & 49 \\
\hline I8 & 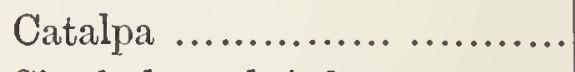 & I & I $\quad 0 \frac{1}{2}$ & I 10 \\
\hline r9 & Single-leaved Ash......... & 4 & I 9 & 24 \\
\hline 20 & Lime $\ldots . . \ldots \ldots \ldots \ldots \ldots \ldots \ldots$ & 1 & $78 \frac{1}{2}$ & 80 \\
\hline $2 I$ & Cupressus Torulosa ........ & $2 \frac{1}{2}$ & 21 & $\begin{array}{c}30 \\
\text { Jan. 27, } 1858 .\end{array}$ \\
\hline 22 & Oak ..... & 4 & 5 & 56 \\
\hline 23 & Plane ....................... & 4 & 56 & $6 \quad 2 \frac{1}{2}$ \\
\hline 24 & Oak $\quad \ldots . . . \ldots \ldots \ldots \ldots \ldots . . . . . .$. & 4 & $5 \quad \mathrm{I} \frac{1}{2}$ & $8 \frac{1}{2}$ \\
\hline 25 & Beech..................... & 4 & 8 I & $6 \frac{1}{4}$ \\
\hline 26 & Elm $\ldots \ldots \ldots \ldots$ & 4 & $2 \quad 6 \frac{1}{2}$ & \\
\hline
\end{tabular}


The changes which occasionally take place in Pond-weeds are very striking, and apparently inexplicable-I have watched them with much interest in a chain of some eight ponds, all fed by the same stream, and occupying together a space of about one third of a mile in length. Until about eighteen or twenty years ago that sea-weed-looking nuisance the Potamogeton crispum was, I believe, unknown throughout the whole of this chain. Shortly after that time the second pond in it became almost covered with this weed, while the upper one was suffering from a scummy infliction (conferea) exclusively. The "potamogeton" pest seemed then to desert the second pond, and move upwards en masse, the scum, which had pervaded the upper pond, giving way to its more powerful rival, which completely filled it, while but one or two minute pieces of the weed were visible in the second. The ponds between the second and the last in the chain remained for some time uninoculated with the new weed, but a great part of the last has now become quite choked up by it, the intermediate ones remaining still almost entirely free from it, and the upper one being comparatively free both from it and the scum which had for- 
merly choked it up. The second pond has since been filled up.

The soil which is observable at the mouths of Earth-worm holes (worm-casts as they are called) by no means consists exclusively of earth thrown up by them from beneath the surface, it being their habit, when returning from their nocturnal peregrinations, to bring with them any light and portable substances which they may come across, and, leaving them at the entrances of their holes, thus shut their doors after them. On a lawn near Winchester, a short time since, I noticed a number of small black pellets collected into heaps in such a way as to make it appear at first that sheep had made their way into the garden, and been straying there. On closer examination however they proved to be composed of acorns from a neighbouring Ilex, which had been carried off, and thus disposed by the Worms.

It is not, I think, generally known that Maggots, admirably adapted for feeding young pheasants and partridges, can be procured from common sea-weed. This should be taken up as near low-water mark as possible, placed in a heap, and allowed to rot, about a fortnight after which 
it will be found swarming with maggots, rather smaller than those bred in flesh. The keeper, from whom I learnt this dodge, a man of considerable experience in his vocation, tells me that he considers them, as food for young birds, superior to flesh maggots, inasmuch as they may be given in any quantity without fear of causing surfeit.

Out of forty-two young Partridges attempted to be reared by a friend of mine in 1853 only one survived, the whole of the others having been carried off by a disease somewhat peculiar, and, I believe, uncommon, manifesting itself by a gathering close to the eye, about the size of a pea, containing matter, which caused the head to swell up to double the natural size. The following year many were carried off by a similar disease, the only difference being that the gathering then took place inside the upper mandible. Many remedies were tried, but none proved successful. Running in the same meadow with these partridges, and treated exactly in the same way, were a number of young pheasants. Singularly enough, however, the disease was exclusively confined to the partridges. Not one of the pheasants was attacked by it, and they remained throughout perfectly healthy. 
White, in his Natural History of Selborne, mentions an idiot boy, who had a remarkable penchant for taking the nests of Bees and Wasps, of the stings of which he was perfectly regardless. I knew a similar instance of a mason's son in the Island, who, with all his wits about him, when about nine years old, had the same fearlessness of wasps. He would take one of their nests, and bring it home in his cap, either not being stung, or feeling no pain from the stings.

We are, happily, comparatively free from Midges in the south of England, but in some parts of Scotland they are sometimes perfectly intolerable. The best simple preventive against their attacks is, I believe, oil-not a pleasant cure, particularly as you feel them trying to crawl after they are stuck in it, but not so bad as the disease. If you anoint your face with this before going into a locality infested by midges, you will soon find it thickly peppered with them, it being in fact for the time converted into a "Catch 'em alive, O!" Deer's fat is said to be preferable to oil, as it does not dry up so quickly, but, if you carry a small bottle of oil in your pocket, you can renew the application at pleasure. Whisky is of no use. I have washed my face with it, but the midges are 
CH. VII.] BIRDS ON SCOTCH SEA-LOCHS.

true to the tastes of their adopted country, and seem rather to like it than otherwise. Tobaccosmoke they do not like, and if you could manage to keep a pipe constantly a-light, and your face turned due to windward, you would hardly require anything else.

I remember a friend of mine one hot afternoon in August passing by a tent which we had set up in the hills on a moor in Ross-shire, and finding a small boy, who had been left there to get dinner ready, sitting in the burn which ran by it, with only his head and hands above water, engaged in plucking a duck (ducking and plucking alternately), having been fairly hunted into it by the midges.

From the way in which some of the lochs on the western coast of Scotland teem with animal life in the way of sea and shell-fish, one would naturally expect their shores to be tenanted in an equal degree by the birds which ordinarily live upon them. In this respect, however, I have been somewhat disappointed, those which one finds along the sides of such lochs being for the most part confined to Curlews, Herons, Oyster-catchers (which are, by the way, very good eating), and Ring Dotterel, none of them often appearing in any 
great numbers. I should perhaps except Curlews, of which one sees a good many occasionally; and Herons, which are very abundant. On one occasion, near the mouth of Loch Duich, about the beginning of September, I saw a very unusual number of these birds on wing together. There must have been several hundred of them, flapping to and fro with a lazy desultory flight, and looking, at a distance, against the dark wooded bank of the loch, like so many great white moths. Ordinarily, a dozen would probably have been the maximum number one would have met with in passing from one extremity of the loch to the other. There appeared, so far as I could make out, to be no particular inducement which could tend to the gathering together of this extraordinary assemblage. Migration naturally suggests itself as a possible cause, but I am not aware that Herons are in the habit of changing their quarters in such large bodies, nor is September the time of year when one would have expected such a movement to take place; unless, indeed, the old birds may have been leading their young ones away from their breeding-stations to their autumn feedinggrounds. They could certainly at that time scarcely elsewhere find a more ample supply of 
CH. VII.] MORTALITY AMONGST SEA-BIRDS.

food, as cuddies (to say nothing of other fish) then abound in all the lochs and bays of that coast to an extent almost inconceivable.

A very remarkable and extensive mortality was observed to prevail this autumn, 1859, (about the months of August and September) amongst several species of sea-birds along the west coasts of Scotland, Ireland, and England, the species more particularly affected by it appearing to be Guillemots, Razor-bills, Puffins, and Gulls, number's of which were picked up along the shore, the greater part dead, but some still alive, though so reduced and helpless that they could be taken up by the hand. A friend of mine in the Isle of Arran picked up in the course of one morning's walk upwards of fifty dead and dying, mostly Guillemots and Razor-bills, but including a few of the two other kinds mentioned.

This mortality was noticed at several different places along the coast, and appeared to have a very wide range, extending as far round on the south coast as Bournemouth. I have been unable to trace it further to the westward, but am informed that there was a marked falling off this summer from the usual number of these birds which annually resort to the Freshwater Cliffs to 
breed. This circumstance would lead to the supposition that there must have been some similar visitation among them last year.

The birds which were thus picked up were, I am told, thin, but scarcely so emaciated as to lead to the belief that they had become thus reduced merely from starvation.

In the absence of any light which may hare been thrown on the subject by dissection or otherwise, of the existence of which I am not aware, the actual cause of this mortality must remain a matter of doubt, but it may probably, without hesitation, be assigned to one of the three followingnamely, starvation, poison, or disease. With regard to the first, it is just possible that from some atmospheric or other cause the fish, which form almost exclusively the food of these birds, may have kept so far out at sea, and so deep, as to be inaccessible to them; or again, they may have been by some means diverted from their usual course-intercepted for instance by the extraordinary plague of Dog-fish, by which the Northwestern coast of Scotland was (as mentioned in page 84 ) visited in the spring of 1858-and thus prevented from reaching their ordinary haunts, where the birds would naturally have depended on 
finding them. The Gulls are said to have apparently suffered less than the other three species, a circumstance which (as Gulls do not feed so exclusively on fish) would, so far as it goes, tend to support this view of the case. The second cause, that of poison, though indeed possible, yet seems so extremely improbable, that I think it may be dismissed as scarcely worth consideration. The last, that of disease, appears to me at once the simplest and most probable. I can see no good reason why sea-birds should enjoy an immunity from epidemics any more than land-birds-Grouse, for instance, which have suffered so severely within the last few years - and to some such visitation I should be inclined to attribute the mortality which has thus raged amongst them. If but one species had been attacked, I should have had scarcely any doubt on the subject, but there is on the whole, I think, less difficulty in arriving at this conclusion than any other.

Had only a few birds been picked up on one part of the coast, their deaths might have been very fairly attributed to weather, but it seems scarcely possible that any storm could have at once so wide a range, and so extensively destructive an effect. 
The skeletons of two Weasels, picked perfectly clean, were found in a wheat-rick on a farm in our neighbourhood, whose death the men employed in taking it in attributed to rats, of which there were also many in the rick. I doubt, however, whether rats ever commit such an act of retributive justice, and should rather imagine that they met their deaths from indulging in a course of poisoned mouse, of which a plentiful supply was at hand. Their bones may have been afterwards picked by the rats, who, being no way particular, may have dined upon them by way of a change of diet.

Another adjoining homestead was about the same time infested by Rats, which seemed to have arrived suddenly, the place having been, until a short time before, almost free from them. Upwards of twenty dozen were caught there in the course of a few weeks. Whilst this work of extermination was going on, as the rat-catcher was one day ferreting them in the barn, the bailiff, who was standing outside, called his attention to a part of the thatch where he heard some of them squeaking. He passed his hand along it, under the impression that there was a nest there, and came presently to a part which was quite warm. Having discorered, or made, a hole communicating 
with the interior, he inserted his hand, when he found that it terminated in a cul de sac full of large rats. He set to work at emptying it, and pulled out and killed, two and sometimes three at a time, no less than twenty-six large rats, several others succeeding in making their escape-not a bad haul, considering that he received two-pence for every rat killed. Whilst doing this he was not once bitten, which he attributed to the fact that he had, by closing the mouth of the hole with his arm, kept the rats in darkness, when he said, you may handle them with perfect impunity. After he was gone, the bailiff thought he would try his own luck at the hole, and, he, in his turn, succeeded in pulling out and adding nine others to the bag. In doing this, however, probably not being so well up to the work as the rat-catcher, he received a pretty sharp bite across one of the fingers. The rats had, of course, been driven into the hole by the ferrets.

I remember, when a boy, seeing an upright skirting-board in some stables stripped off, in order to discover the cause of a villanous stench which issued from it, when it was found to proceed from the bodies of nine large Rats, in a state of putrefaction, closely jammed together with their heads 
downwards. They had evidently taken refuge there when the premises were ferreted sometime previously, and been unable to back out again. 


\section{CHAPTER VIII.}

Determination of Sparrow-haw -Boldness and voracity of Stoat-Jays-bait for-Flocks of Magpies-Jays, Magpies, \&c. subject to fits-Raven-Cats-Barn-owls-Kestrels-Foxes.

$W^{\text {HILE partridge-shooting a year or two ago }}$ I put up a covey of birds, and, following them with the keeper, came across one which had just been knocked down by a Hawk. He at once set about taking preliminary measures for the apprehension of the offender, by pegging down the bird, placing a small bush at its head, and otherwise limiting the hawk's approach to it by a little avenue of sticks, between which the gin was to be set after our day's shooting was over. Having expressed a wish to see the hawk if he caught it, the next morning, as I was sitting down to breakfast, I was told that he wanted to speak to me, and, on going out, found him with his prisoner, a hen Sparrow-Hawk, alive in the gin, which had her fast by one leg. From the claw 
of the other was still suspended, firmly clutched by the neck in her strong gripe, the partridge, of which she had never for a moment relinquished her hold from the time she was taken up, although it had been thus suspended during the whole of his walk to the house, a distance of fully half a mile; so loth was she to part with her ill-gotten booty.

The following singular instance of the boldness and extreme voracity of the Stoat came under my notice about the same time. I was riding up a lane accompanied by a retriever, when he went to investigate the mouth of a drain closed in by loose stones, but immediately jumped back, evidently startled by something-a snake, as I thought. I rode up to see what it was, and he went to have another look at the place, but again retreated, repelled, as I then heard, by a determined spitting hiss. Upon this I got off my horse, tied him up to a gate, and went to satisfy myself as to the nature of the beast from which this noise had proceeded, when I was in my tur'n similarly saluted, whilst I could distinguish some animal rushing to the mouth of the drain. I then saw something protruding from it, which turned out to be the hind-quarters of a young rabbit stuck 
in the stones at the entrance. On attempting to pull this out I found myself resisted by some force pulling hard at it from within, but succeeding, not without some difficulty, in doing so, it was followed by the head and shoulders of a stoat, making most angry and energetic demonstrations of hostility, and accompanying them with the same savage hiss that I had before heard. I tried to get hold of him, but he avoided coming to close quarters, luckily for my fingers, so I had my cowardly satisfaction by calling in the aid of a keeper, who lived not far off. He laid siege to the place with gins, and a campaign of a couple of days or so resulted in the capture of an old mother stoat and six young ones nearly as large as herself. I was rather conscience-stricken, when he told me that he had first caught the old one, and then a young one, using her body as a bait; thinking it was a strong case of seething the kid in its mother's milk. I might, however, have spared myself any such scruples, for the affectionate infant had, as I found, come to his mother, not to suck but to eat; and, in fact, not only did he and his brothers and sisters finish her, but the whole of this united family, save one who made his escape, eat one another up, the surviror going off with the whole 
of the family blood, if not honours, concentrated in his person. The keeper wound up his account of his share of the transaction by saying he believed that a stoat would at one meal eat up another as big as itself.

Jays are of some slight service to game-preservers in giving pheasants notice of the approach of danger. If you are perfectly concealed from pheasants as they come to their feed, but exposed to view from above, and a jay happens to catch sight of you, at his first warning "squark" every pheasant will take the hint and be off instanter. But, although there is this redeeming point in their favour, yet the havoc which they commit amongst the eggs of game, to say nothing of young birds, which I have no doubt they are not averse to picking up occasionally-I have seen one carry off a good sized young thrush-renders it the interest of every game-preserver, and the duty of every keeper, to get rid of them as fast as possible. To effect this no plan will, I believe, be found to answer more effectually than sham eggs as baits with a gin. They should be turned out of wood-birch answers very well-and coloured and varnished to represent the natural ones. Thrush's are perhaps as good as any for the 
purpose, as they shew well, and are easy of imitation. Of course the closer the resemblance is, the better, but even if it be but rudely approximated to, the success of the bait is extraordinary. Four or five of these eggs should be placed in a sham or real nest on a stage made against a tree a few feet from the ground, leaving just room for the gin, which should have a little branch or two on either side of it, so as to bar access to the nest save viâ the gin. The peculiar advantages of this plan are that it can be pursued with destructive effect (somewhat strange to say) all through the winter, when natural eggs are not easily attainable, and that the sham eggs can be carried loose in the pocket without fear of breaking them.

I have occasionally seen Magpies on high, exposed, down-land collected together in such (for them) extraordinary numbers-from twenty-five to thirty in a flock-that I cannot but think they must be to a certain extent nomads, and shift their quarters in company, like swallows; particularly as I am persuaded that the immediate neighbourhood could not, unaided, have furnished so many, and these flocks have, so far as I know, only been seen early in the Spring, long after 
246 Jays, magpies, \&C. SUbJect to Fits. [PART it.

the young birds would have ceased to depend on the old ones.

Tame Jays and Magpies, even when allowed all the liberty consistent with a clipped wing, appear to be very subject to cramp and fits, which are often fatal to them. Of several individuals which I remember being reared at home, not one, I think, survived these attacks, though one or two attained their full growth.

A tame Raven, which we had, was also similarly affected, but he made his escape at a comparatively early period of his life. He used besides to execute most extraordinary antics, making now and then, all of a sudden, a desperate rush half flying and half running, throwing a summerset as he did it, and accompanying the performance with a loud and peculiar croak.

We at the time were inclined to attribute these freaks to fits or insanity, but it was suggested, and perhaps with truth, that his object might have been simply to scratch his head. Gilbert White in his Natural History of Selborne mentions that he had noticed them turn over during their flight, possibly, as he conjectures, for that purpose, and perhaps our raven could not, under the circumstances, have managed 
CH. VIII.] RAVEN-CAT-BARN OWL-KESTREL. 247

it better. Ravens are not at all numerous in the Isle of Wight, although they enjoy there very generally the advantages accruing from the superstitious respect with which they are so commonly regarded, as but few of the lower orders would be found bold enough to kill one. The tame one that I have mentioned, when he made his escape, commenced his peregrinations by getting on the porch of a cottage, and nearly frightened the inmates out of their wits by croaking in at the windows.

Probably there is no kind of vermin more destructive to game than the Cat, but fortunately also there is perhaps none which is more easily trapped. An instance has been mentioned to me where a large, long-neglected covert having been taken in hand for game, the keeper, a knowing hand, commenced operations by leading a drag of rabbit's entrails from several points in the sides of the covert to a central tree in it. From a branch of this he suspended the drag, setting a number of gins all round it, and was next morning rewarded by finding them tenanted by a regular flock of cats.

Opinions little favourable to the common Barn Owl and Kestrel are not unfrequently expressed 
and acted upon with reference to their supposed destructiveness to game; and considering that every other kind of Hawk (properly so called) and $\mathrm{Owl}$, which are at all common here, are undoubtedly very destructive to it, it is not at all surprising that these two should have been often classed in one common category and indiscriminately proscribed as vermin.

Now as to the Barn Owl, I believe there never was a bad name more undeservedly given. It is just possible that under the influence of hunger he may be driven to pick up a very small leveret or young bird (though I have never heard of such a case), but his ordinary food undoubtedly consists almost exclusively of mice and rats, and his presence is therefore a positive benefit to the farmer and gardener, and an advantage rather than otherwise to the game-preserver, rats being decidedly enemies to game. A friend of mine tells me that he saw the other day a rat engaged in hunting a young rabbit as regularly as a stoat might have done it.

Of the Kestrel I am sorry to be unable to speak quite so respectfully. There is no doubt that, as Yarrell says, "Mice constitute by far the most considerable part of their food," their diet being 
occasionally varied by small birds, coleopterous insects, their larvæ, and earth-worms. Yet occasionally, and particularly where they have families to provide for, they are not contented with such "small deer," but will make free with young pheasants or partridges, sometimes even carrying their audacity to the extent of making a raid on the chicken or pheasant coop. I had one day paid a visit to a gamekeeper during the summer to see how his young birds got on, when he reported "all well," except that he had been "terribly bothered with one of they nasty "vanner hawks " (Vecticè for kestrels-qu. wind-fanner), which had carried off several of them. On my expressing some doubt as to whether the offender was really a vanner, he said he was quite sure of it, and hoped shortly to give me ocular demonstration of the fact; nor did he leave it long doubtful, for on my next visit a day or two afterwards he shewed her to me, an undoubted female kestrel, which he had shot in flagrante delicto, in the very act of carrying off one of his young pheasants.

While on the subject of vermin I will say a few words on the subject of our dear friends and enemies the Foxes-friends to all those who, like myself, would sooner be with the hounds through 
one good run than carry a gun at ten of the best battues that the country can afford-enemies to those, who, preferring shooting to hunting, preserve game to the exclusion of foxes. And I will do so without reserve, because I think it is due to those gentlemen (and there are many) who, although they preserve game and do not hunt, yet preserve foxes simply for the amusement of their friends, that an ample acknowledgment should be made to them for their kindness, and that no attempt should be made to blink or depreciate the sacrifice which they are thus liberal enough to make for the benefit of others.

I believe the Fox to be about the most indiscriminate of our carnivorous animals, nothing from a hare to a mouse coming amiss to him; and that the different descriptions of game suffer more or less from his attacks, only just in proportion as they are more or less accessible to him. For that reason I believe that hares suffer most, and next to them partridges. Foxes have been said to be so fond of rabbits that they will touch nothing else if they can get a sufficient supply of them. Doubtless they are-very fond of them, but the young rabbits are protected by being snugly under ground, whilst the unfortu- 
nate leveret is utterly defenceless, and must fall a victim to the first fox that happens to pass to leeward of it. Old hares too, though better able to take care of themselves, must often fall victims to their cunning foe, when old rabbits would be out of his reach. The lives of young pheasants and partridges would, quâa foxes, probably be insurable at about equal rates until the former are able to go to bough; but, after that, pheasants are comparatively exempt from danger, while a covey of partridges clustered all together at night must be as easy and tempting a prey as a fleet of goldladen galleons without a convoy would have been to a man-of-war in the olden time. I know an estate in a part of the country where there were formerly no foxes, on which, before their introduction, sixty or eighty hares were not unfrequently killed in a day's shooting. Since then, however (the coverts on the estate in question affording an excellent harbour for foxes), the number of hares on it has been gradually decreasing, and now it is almost rare in a day's shooting to kill a tenth part of the former number.

Besides the game actually taken by foxes as food, they indulge, I regret to say, in the very 
reprehensible practice of wantonly killing more than they can consume, for the mere fun of the thing, or perhaps to keep their hands in. The following instance of this fell within my own observation. On coming down to breakfast a few years ago, while staying with a gentleman in the South of England, I was horrified at seeing on the hall-table one of the largest-sized kitchen-trays covered with young pheasants laid out in order, fine forward birds, the ruddiness of the plumage of some already denoting the sex. Passing on, I went into the dining-room, where I was accosted by my host (who, though not loving foxes per se, had, I must say, been always most liberal in preserving them, from the time he found he could contribute to the public amusement by doing so) with "Well, you see what your friends, the foxes, have been doing." "Oh!" I said, "it can't be a fox, it must be a dog." "No dog," answered he ; "but as to that you can easily satisfy yourself." I did so, and found sure enough, to my disgust, that he was right. Some young birds, brought up by hand, had been placed, together with the hens in coops, in a piece of long grass near the house, a certain quantity having been left uncut for that purpose. Amongst these a fox or foxes had been 
running amuck during the night, and his or their bag had amounted (I think) to forty-eight. Of this number two only were missing, the corpses of the remainder lying scattered here and there, as if they had just been nipped and left where they were caught. So little signs of violence did they exhibit, that only two, I believe, out of the whole number were minus their heads. The position of one bird was very remarkable, as shewing the trouble taken by the fox in the attainment of his nefarious ends. One side of the piece of grass in which the birds lay was separated by a somewhat deep and broad ditch from a rather high bank, topped by a blackthorn hedge which rose fully six feet above it. It was easy in the long dewy grass to follow the tracks of the fox or foxes, one of which led me to the ditch. This he had crossed, and, pursuing the investigation, I found to my surprise that he had actually worked his way right up the centre to the top of the hedge, caught and killed there a pheasant which had doubtless flown thither for refuge, left it there as evidence against himself, and descended again by the way that he went up. There could be no doubt of the fact, for, the hedge being a thick one, he had left on the thorns no inconsiderable quantity of his coat en route. 
A keeper, on an estate in a part of the country where the friends of whom I am speaking are strictly preserved, told me in confidence another anecdote which will tend to throw some light on their tastes and habits. "Call you this a backing of your friends," some one may ask, "to betray this confidence, and rake up unseemly stories to their discredit?" Now, as between the keeper and myself, no names being given, there is, I conceive, no breach of confidence; and as, with regard to the foxes, I started with the avowed intention to "nothing extenuate, nor set down aught in malice," I will take the liberty of proceeding with my story. The keeper, in spite of endless precautions and diligent watching, one night lost, in killed and missing, upwards of a hundred young pheasants and partridges, besides having several of his nursing hens killed and others maimed by the foxes, in their endeavours to drag them through the bars of the coops. This was too much for his patience, and, finding a good many of the young birds buried in the vicinity of the place, he, "unbeknown to" his master, who was a stanch protector of foxes, set some gins by them. About a week elapsed without any result, but at the end of that period he found in one of them an old 
vixen fox, and by her side three fine young pheasants, part of the buried plunder, which she must have dropped when caught. She had evidently been waiting until the birds were sufficiently "kept," and was going her rounds to replenish her larder with them. "I suppose you let her go," I said. "Oh! in course I did, Sir," answered he, but with the slightest suspicion of a chuckle, as I fancied. Whether or no he did so, remains a matter between him and his conscience; but all I can say is, that if he did, he must have been a keeper of a very unusually charitable and forbearing disposition.

With regard then to the charge of poaching against our "friends," I must, as an honest man, though reluctantly, return a verdict of guilty, coupling it, however, with a strong recommendation to mercy. It is all very well, in pleading for them with farmer's' wives, gamekeepers, and others, who cannot be expected to look upon them with very favouring eyes, to

Be to their faults a little blind,

Be to their virtues ever kind;

but it is, I repeat, in my opinion, but fair to those who injure their own sport for the sake of others, that the extent to which they do so by preserving 
foxes, should be felt and acknowledged by those who reap the benefit. Those who hunt as well as shoot, may well sometimes say of them, as an old garden-man used of my brothers and myself when we were boys: "Well, they did plague me sometimes, but I did love 'em, 'od rot 'em-bless 'em."

NoTE.

Tre following letter, for which I am indebted to the kindness of a friend, has reached me too late for incorporation with my Notes; but the incident to which it refers is so remarkable in itself and so strikingly illustrative of the voracity of the Pike, before alluded to (page 43), that, rather than omit it, I must ask the Printer to give it here a separate place.

MY DEAR H.

Bartonyere, Suffolk.

You ask me about the Pike who choked himself to death and was survived by his dimner.

One day, some years ago, I was fishing from my punt on the Mere, and saw something moving oddly about just beneath the surface of the water a few yards off. I paddled up, and found a Carp of about two pounds weight swimming blindly round and round with a Pike on his nose. The Pike was dead and limp-several leeches had already fastened upon him-but the Carp could not shake or rub him off, the Pike's teeth turning inwards and entering deeper the more the Carp withdrew. I took them both into the boat, and released the Carp. After measuring him and finding him considerably bigger than the Pike, I put him into the water again and he swam off with a light heart, but a very sore nose. HARRY JoNES. 


\section{N D E X.}

A.

Animals, Fancies taken by, 185

"Tameness of, on Sundays, 212 Anser albifrons, 204

Ardsheal, Fishing off, 96

Arran, Mortality of Sea-birds off Isle of, 235

Asses, Wool on heads of young, 217

Avon, Effect of Kill-devil on the (Devonshire), 26

" Fly-fishing on, 56

, Jack will take artificial bait freely in (Hampshire), 20

B.

Babies, Down on foreliead of, 217

Badger, Ineffectual attempt to poison, 177

Bait for Jays, 244

Baiting, for spinning, 12

Baits for sea-fishing, England, 73

Bala, Kill-devil from, 23

\section{Scotland, 74}

" Barley-bird," 205

Barn-Owl, harmless as regards game, 248

Belt, 102

Birds, fascinated by human eye, 182

, Return of migratory, to same haunts, 194

, Plea for rare, 207-211

" Rarer, Visitors to Isle of

Bittern, 203
Blackber'ies in winter, 151

Black Viper, 172

Boat-dress for wet weather, 100

Bones, Fondness of cattle for, 178

Bournenouth, Sea.birds found dead offi, 235

Brambles, Fishing oft tlie, 98

Brambling, 204

Breeding-season, Influence of on birds, 154

Brussels, Fish-ponds near, 38

"Bull-bird," 206

Bunting, Cirl, 204

$$
\text { " Snow, } 204
$$

Buntings, Visitation of, 197

Button, Covering for Rod, 5, 6

Buzzard, Death of, 192

Buzzards, Anecdote as to breeding of, 193

\section{C.}

Caledonian Canal, 117

Cap, Scatwell, 102

Cape, 99

Carp, Basking, 36

,Eels and Eschylus, 37

, How to eatch, 33

, Increase of weight in, 40

, Large, 38

"Noises made at night by, 48

" spawn devoured by birds and fish, 51

Spawning of, 50

taken with live minnow, 53

Tame, 36 
Cat bitten by Lizard, 171

, very destructive to game, 247

Caterpillar, Fly tailed with, 65

, Paralyzed, 146

Cattle, Fondness of, for bones, 178

Cedar of Lebanon, growth of, 226

Charning away warts, \&c. 183

Charadrius œdicnemus, 206, 209

, $\quad$ liaticula, 206, 233

,, morinellus, 206

, pluvialis, 206

Clearing line, Simple, 62

Cockles, 74, 109

Cod, 82, 98

, caught by Dog, 131

Codlings, 77, 82

Colour of Fly, 56

, Flat-fish changing? $10 \mathrm{r}$

Conferva, 229

Conger-eels, 83, 133

Creran, Loch, 27, 80

Cuddies, Fishing for, 75

,, astonishingly numerous, 81

Cur baptism, 190

Curlew, 233

Curlew, Stone-, 206

, Murder of, 209

\section{D.}

Dace caught with spinning bait, 52

Darwin's Naturalist's Voyage, 147

Deer, Horns shed by, how disposed of ? 179,180

"Dodger," 73

Dog made sick by smell of Goat, 181

Dogs, Anecdotes of, 128, 181, 186, $190,191,213,214$

Dog-fish, Plague of, 84, 235

"Small spotted, 8:3

Dog-fisler, 128

Donacia, 149

Dotterel, 206
Dotterel, Ring, 206, 233

Double live-bait tackle, 29

Dragonet, Gemmous, 83

Dress for boat-work, 99

Drum-net, 86

Duich, Loch, 137, 234

E.

Earth worm, Casts of, 230

Eau de Lyon, 66

Eel, 37

,, caught with $\mathrm{fly}, 54$

,, -spearing, 109

,, held in abhorrence by Scotch, 133

, Conger, 83, 133

Egg-shells, Disposition of, 167

Elephants, Fleece on young, 217

Ember-cooking fish, 116

Erme, The, 107

Estremadura, Large Lizard in, 171

Birds in, 172

Executioner for Jack, 31

$$
\text { , Sea fish, } 79
$$

Eye, Bir ds fascinated by human, 182

F.

Fancies taken by animals, 185

Fascination of birds by human eye, 182

Fastening for Casting-line, 58

$$
\text { , for Bob-flies, } i b \text {. }
$$$$
\text { , for Reel, } 62
$$

Findhorn, An afternoon on the, 138

Fish, Deceptive appearance of, in water, 111

„Improving breeds of, 45,46

Fisher-dog, 128

Fishing from steamcrs, 94

Fish-taxidermy, 104

Flat-fish, Spearing, 107, 109

Fly-fishing, 55 et ser. 
Fly-fishing in sea-lochs, 75

Fox, White, 177

"Fox-hunter," The, 134

Fox-hunting in the Highlands, 135

Foxes $v$. Game; anecdotes, \&c. 249 256

Frencham pond, Little, 54

Freshwater, Brecding of Peregrine Falcons at, 195

, Decrease in number of sca-birds breeding at,235

Fringilla Montifringilla, 204

G.

Gaff, essential in sea-fishing, 78

, Make-shift, 60

Gaff-handle, Colour of, 16

Gag for Jack, 31

Gairloch, 95

Game, Foxes v.; anecdotes, \&c., 242256

Gannet, 203

"Gânser," 74

Garry, Loch, 117

Gemmous Dragonet, 83

Geneva, 64, 65

Gentle, Tailing fly with, 64

Gimp, 14

Glen Coich, 118, 127

, Garry, 116

Glomach, Trout in the, 137

Gloves, How to pair, 103

Goat, Stinking, 180

Goose, White-fronted, 204

Gosse, Letters from Alabama, $14 \mathrm{~S}$

Grass scarified by Rooks, 215, 216

Grass-hoppers, as bait for Carp, 37

Grass-hopper Warbler, 205

" Great Spotted Ling," 139

Grouse, Eggr-shclls of. how disposed, 167
Guernsey, Fishing off, 96

Guillemots suffering from diseasc, 235

Gulls suffering from disease, $i b$.

, Habits of tame, 156

"Tameness of, in general, 158

,Weather foretold by flight of, 160

Haddock, 83

H.

Hair, 63

Hake, 82

Hand-coiling line, 15

Hare, Star on forehead of, 223

Harlequin duck, Murder of, 209

Hatching by Pheasants and Hens compared, 169

Hawk, Determination of Sparrow-, 241

Hermit Crab, 73

Herons, Great flock of, 234

Herring, as bait, 74

„ taken with bait, 97

, fry, 9s

Himalayan Pheasant, 168

Hobby, 204

Hooks, Flights of, 12

Hoopoe, 204

Horns shed by Deer, how disposed of, 179

Horses, Anecdote of Carriage-, 213

House Sparrows flock together before hard weather, 223

Hugh Miller, 107

Hutton, Lieut., 148

Hydrocampa stagnalis, 149.

I.

Iford, Jack-fishing at, 111

Isle of Wight:-See "Bunting"

"Jack Daws"

"Percgrine Falcon"

"Rarer Birds"

"Raven" 
Isle of Wight :-See "Sea-birds" "Squirrels" "Starlings" "Stock Dove" "Trees"

"Wood-pigeon"

Isle of Arran, Mortality among Seabirds off, 235

\section{J.}

Jack, Artificial baits for, 20

, Increase of weight in, 42

, Large, 113

, Spinning-tackle for, 5

" taken with dead bait not in motion, 21

" taken with fly, 54

" to be struck sharply, 19

, Voracity of, 43,256

Jackdaws, building in winter, 150

"Jays and Nutcrackers," 162

" Bait for, 244

" Tame, subject to cramp and fits, 246

Jura, The, 65

$$
\text { I. }
$$

"Kennan-craw," 139

Kestrel at times destructive to game, 249

Kill-devils, 22

$$
\begin{array}{ll}
" & \text { on the Wandle, } 22 \\
, & \text { in Deronshire, } 26 \\
, & \text { in salt-water, } 27
\end{array}
$$

King-fish, 82

Kingie, Loch, 118, 121, 127

Kitten, Attachment of, 188

Knickerbockers, 101

\section{I.}

Lady-birds at sea, 99

Landing-handle, Colour of, 16
Landrail, 218

, Large bags of, 219

Lily, Water, Larvæ under leaves of, 148

Line, Spinning, for Trout, 7

Ling, 83

, Great Spotted, 139

Linnhe, Loch, 96

Little Loch Broom, 95

"Live Ground-baiting," 32

Lizards, Two linds of land, 170

" Large, in Estremadura, 171

Lobsters, 85

$$
\text { , Trap for, } 83
$$

Loch Creran, 27, 80

, Duich, 137, 234

, Garry, 117, 127

, Linnhe, 96

" Tingie, 118, 121, 127

"Polery, 118, 120, 127

Lochs, Birds on Scotch Sea-, 233

, Fish in ditto, 81

London, The, 66

Loxia Coccothraustes, 205

Lug-worm, The, 73

Lyon, Eau de, 66

Lythe, 77

M.

Macaw, Fancy taken by, 187

Maclierel, 73, 77

Maggots from Sea-weed, 230

Magpies, Flocks of, 245

, Tame, subject to fits, 246

Maidenhead, 18, 21

Maltby, Mr, Management of fish by, 38

Martin, Sand, 164

Mason Wasp, 145

Merlin. 204

Mice, Nuts brought out of woods by, 222 
Midges in Scotland, 282

Miller, Hugh, 107

Moles, Strength of, 176

, Popular notion respecting, $i b$.

Moorhens, destructive to fish-spawn, 51

" Lofty fight of, at night, 218

Mortality among sea-birds, 235

Mushrooms not eaten by Highlanders, 136

Mussels, 74

$" \quad$ in Loch Creran, 80

My Schools and Schoolmusters, 107

N.

New Forest, 21

\section{,Wood Pigeons attracted}

to, for beech-mast, 200

Nightingale, Murder of, in Deronshire, 209

"Norway Widgeons," 197

Nurse, 83

Nuts and Nutshells on Down, 222

Nymphosolis, 149

O.

Odynerus parietinus, 145

Overalls, 99

Oyster-Catcher, 233

Oysters, 81

Owl, Barn, harmless as r'egards Game, 248

Ox-bird, 206

P.

Parrots, Anecdotes of, 162 et seq.

Partridge, Anecdote, of 156

Disease among young, 231

, Disposition of egg-shells of, 167
Peewit, 215

Pelopous flavipes, 148

Peregrine Falcons, Breeding of, 195

Perch in ponds near Brussels, $4: 3$

" taken with fly, 54

Phalarope, Rednecked, 203

Pheasant, Disposition of egg-shells, 167

, Hatching by, 169

, Himalayan, 168

" Small eqgrs of, 169

" White, 168

Phœnicura tithys, 204

Pigeon, Wood, 154

Pike survived by his dinner, 256

Plectrophanes nivalis, $20 t$

Plover, Grey, 206

" Golden, $i b$.

Polery, Loch, 118, 120, 127

Pompilus, 146

Potamogeton crispum, 229

"Puddock-stools," 137

Puffins, suffering from disease, 235

Q.

Quail, 219

R.

Rail, Land, 218

, Large bags of, 219

Rats, Good liaul of, 239

, in a fix, 239

Ravens, subject to fits, 246

, Superstitious respect for, 247

Red-nccked Phalarope, 203

Redstart, Black, 204

" Common, ib.

Ring Dotterel, 206, 233

Rings for Rod, 6,7

Roach, Increase of weight in, 467

" Tameness of, 51

Robins, Tameness of, 152

, fascinated by human eye, 182 
Rockling, Three-bearded, S3, 86

Rod, Spinning, 4

, rings, 6,7

„, spear (cut-and -thrust), 61

Rooks, Bareness at base of bill, 217

Grass scarified by, 215,216

Ryde, Spearing Flat-fish off, 109

\section{S.}

Saithe, 82

Salicaria locustella, 205

Salmo ferox, 118

Salmon, Disease in, 88, 89

" following the line when hooked, 90

" and Sea-trout, Numbers of, 87

, taken in Sea-loch, 88

Sand Martin, 164

Sap, Great discharge of, 225

Scatwell Cap, 102

Scotch Lochs, see "Lochs"

Sea Brean, 83

" Birds, Mortality among, 235

” Devil, 83

" fishing, 69

$" \quad " \quad$ Stern of boat best in, 67

",$\quad$ Tackle for, 72

" lochs, A nimal life in, 80

" Birds on, 233

" Gull, see "Gull"

"Weed, Maggots from, 230

Shells, Disposition of egg-, 167

Shell-fish, in Scotch Lochs, 80

Shrimps, as bait, 73

, eat their own exuvia, 180

Sillock, 82

"Silver Haddie," 83

Skate, 83,98

” Sour, 140

Skin, Swellingr of, from fish-dict, 139
Small spotted Dog-fish, 83

Suake and Eel, 174

"Fetidness of Common, $i b$.

"Snakes and Puddock-stools," 187

Snipe, 221

Snooding, 86

Snow Bunting, 204

Spain, Large Lizard in, 171

Spaniel, Anecdotes of, 181, 186, 190, 191,213

Sparrow-Hawk, Determination of, 241 Sparrows, House, flock together before hard weather, 223

Spate, Artificial, 89

Spear, Cut-and-thrust rod, 61

Spearing Flat-fish, 106

Sphex, 146

Spinning, Directions for, 3

" Rod for, 4

, Tackle for, 9

Spoonbill, 203

Sprats, 139

Squaterola cinerea, 206

Squirrel, Fancy taken by, 187

Squirrels, 221

Stag's shed-horns, how disposed of? 179

Starlings, Breeding of, in Isle of Wight, 195

" Vast flock of, 196

Steamers, Fishing from, 94

Stenlock (or Stedlock), 82

Stickleback, Nest of, 110

Stoat, Boldness and Voracity of, 242

Stock Doves, Flocks of, 201

Stoddart's Angler's Companion, 117

Stone-Curlew, 206

$$
\text { " Murder of, } 209
$$

Storm, Singular effect of, 224

Stour, The, 20, 111

Striking Jack, 19

Sundays, Tameness of A nimals on, 212

Swallows killed ly parasites, 165 
Swan feeding young, 160

Swivels, 12

'I.

Tailing fly with gentle, 64

Taxiderny, Fish, 103

Teddington Weir, Trout caught at, 105

Teign, The, 107

"Tell-tale," 73

Tench, 45

Tennent's, Sir J. E., Ceylon, 148, 217

Three-bearded Rockling, 83, 86

Toads eat their own exuvia, 180

Tomdoun, 118

Trace for Spinning, 9

Trailing in Lakes, ẩ. 67

Trees, Comparative growth of, 228

Tringa variabilis, 206

Trout, Spinning-rod for, 4, 5

, Large, at Carshalton, 24

, in Devonshire, 26, 56

, Large Thames, 105

, Deformed, 137

, in the Glomach, $i b$.

" in the Findhorn, 138

" of same size haunt same

9 liarbour, 195

Turkey-cock as Nurse, 166

Turnip-crop, Increase of WoodPigeons induced by increase of, 198

V.

"Vanner," see " Kestrel"

Versoix, 65

, Lines on, 66

Viper, Black, 172
W.

Wandle, The, 24

"Wants," 176

Warts, Charming of, 183

Wasps, Boy fearless of, 232

, Mason, 145

Water, Deceptive appearance of fish in, 111

, lily leaves, Larvæ under, 148

Weasels, Skeletons of, in ricks, 238

Weather, Birds deceived by, 150

, Hard, foretold by flocking together of HouseSparrows, 223

Weeds, Pond, Change in, 229

, Sea, Maggots from, 230

"Wretting" fish, 93

Weybridge, Sand Martins at, 164

Wharfe, The, 6:

Whistle-fish, 83, 86

White Pheasant, 167

White-throat, Tame, 15:

Whiting as bait, 74

, -fishing, 98

,, Pollack (Cole), 73

Wide-awake, Oilskin, 99

Wimborne, Lizards near, 171

Winkles, 81

Woodcocks, breeding, 220

, Carrying young from place to place, $i b$.

, Return of, to same haunts, 194

Wood-pigeon, 154

,$\quad$ Increase in numbers of, 197

W orm-casts, 230

Wryneck, 205

Y.

Yunx torquilla, 20:) 


\section{cambrioge:}

PRINTED HY C. J. CLAY, M.A. AT THE UNIVERSITY PRESS. 
(2)

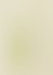

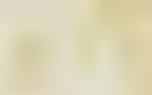

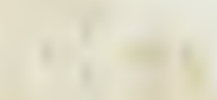

$\sqrt{2}+x^{2}$

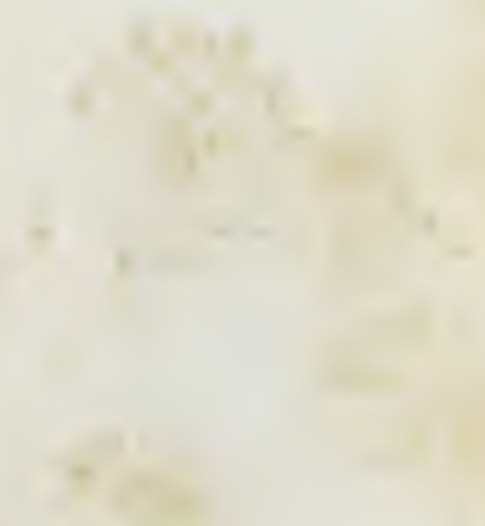






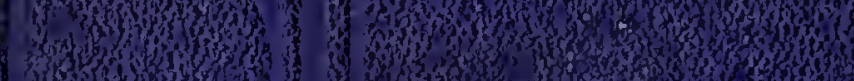

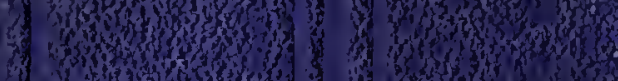

1.7.

whom

3.

M.

mol 